\title{
Comments on Uralic historical phonology
}

\author{
László Honti \\ Department of Hungarian Linguistics \\ Károli Gáspár University of the Reformed Church in \\ Hungary \\ hontilas@t-online.hu
}

\begin{abstract}
In this paper, the author poses three questions of historical phonology and gives explanations that are meant to be rational:

1. With respect to the Hungarian reflexes of Proto-Uralic/Proto-Finno-Ugric/Proto-Ugric word initial ${ }^{*} p,{ }^{*} t$, and ${ }^{*} k$, two reasons are suggested for the dual reflexes ${ }^{*} p>\mathrm{H} f \sim b$ and ${ }^{*} t>\mathrm{H} t \sim d$ : (a) the word internal (primary or secondary) voiced consonant triggered the assimilation (that is, voicing) of the initial consonant; (b) subsequently, due to an effort to eliminate homonymy, the closest congener of the initial consonant (that is, its voiced counterpart) replaced the original voiceless stop. It is also discussed why ${ }^{*} k$ does not similarly have dual reflexes $(k \sim g)$ in Hungarian.

2. Concerning the phonological reality of Proto-Uralic/Proto-Finno-Ugric/Proto-Ugric * $\delta$ and ${ }^{*} \delta$, as well as the potential etymological correspondence of $s$-initial Finnic words with $t$-initial words of the other Uralic languages, it is proposed that * $\wedge$ and ${ }^{*} \wedge$ should be assumed rather than ${ }^{*} \delta$ and ${ }^{*} \delta$, and the correspondence "Finnic $s-\sim$ other Uralic $t-$ " is explained by positing a PU/PFU * $\vartheta$.

3. Reflexes in present-day Uralic languages of the PU/PFU word internal clusters " ${ }^{*} / /^{*} r^{\prime} /{ }^{*} r{ }^{*} j /{ }^{*} \delta\left(={ }^{*} \Lambda\right) /{ }^{*} \delta$ $\left(={ }^{*} \wedge\right)+(\text { some vowel }+)^{*} m$ " are explained by the palatalisation and subsequent semivocalisation of the first consonant; the resulting semivowel either remained as it was, or underwent partial assimilation to the other consonant, or it was dropped: " $C>C ́ \dot{C}>\emptyset / n$ ".
\end{abstract}

Keywords: Proto-Uralic; Proto-Finno-Ugric; etymology; phoneme system; reconstruction

In 2011, an important event occurred with respect to both Finno-Ugric and Hungarian historical linguistics: the publication of András Róna-Tas' and Árpád Berta's two-volume monograph entitled "West Old Turkic: Turkic loanwords in Hungarian" (Róna-Tas \& Berta 2011a and 2011b). Reading this gigantic work, I found I had to take a closer look at certain etymological and historical phonological issues. The present paper contains my reflections on these issues, as well as on certain problems that are not included in Róna-Tas \& Berta (2011a;b) but are necessary to discuss first so that I can satisfactorily answer the questions that arise.

In the monograph, a plethora of historical phonological observations are made, most of them written by the first author. Several of his 
etymological remarks and arguments prompted me to reconsider a number of traditional claims that Professor Róna-Tas argued against. In what follows, I will give an account of (i) Hungarian reflexes of Uralic (U), Finno-Ugric (FU) and Ugric $(\mathrm{Ug}){ }^{*} p$-, ${ }^{*} t-,{ }^{*} k$-; and (ii) reflexes in the daughter languages of word internal $* m$ and of clusters containing it.

Before my discussion of the relationship between $\mathrm{U} / \mathrm{FU} / \mathrm{Ug} *_{3} m_{3}$ and ${ }^{*} C(3) m 3$ and their reflexes in Hungarian in section 3, I inserted a section on interdental spirants in the early history of Hungarian (section 2). This was made necessary by the fact that I had to introduce certain modifications to the usual account of the history of the Uralic consonantism (that is, in that section, I do not focus on the claims in Róna-Tas \& Berta 2011a;b).

\section{PU/PFU/PUg word initial consonants and their dual representation in Hungarian}

In this section, I will discuss the emergence of $\left({ }^{*} p>>\right) \mathrm{H} f \sim b,\left({ }^{*} t>>\right)$ $\mathrm{H} t \sim d$, and $\left({ }^{*} k r>>\right) \mathrm{H} h r \sim k \ddot{\delta}$.

The developments $\mathrm{U} / \mathrm{FU} / \mathrm{Ug}{ }^{*} p$ - $>\mathrm{H} b$ - and $\mathrm{U} / \mathrm{FU} / \mathrm{Ug}{ }^{*} t->\mathrm{H} d$ have always intrigued both Finno-Ugrists and scholars working on Hungarian historical linguistics. Recently, it was taken up again by Róna-Tas \& Berta (2011a;b). Róna-Tas formulated his standpoint as follows:

"PFUgr /p/ was preserved in PUgr as /p/ in initial position and became /p/ in EAH and $/ \mathrm{f} /$ in $\mathrm{H}$ in 56 cases (39 PFUgr $+17 \mathrm{PUgr})$.

PFUgr *pal'a(-) > PUgr *palə- (> POUgr *pol'> PVog *pāl-, POsty *poy) $>\mathrm{EAH}<*$ palə(-) $>$ faje $(-)>\mathrm{H}$ fagy $(-)$ 'to freeze, frost'.

It has been suggested that initial $/ \mathrm{p} /$ in a few cases changed into /b/ in H. According to most scholars in FUgr studies this occurred before voiced consonants at the onset of the second syllable. I have serious doubts.

$\mathrm{PFUgr} *$ pola $>\mathrm{PUgr}{ }^{*}$ polə $(>\mathrm{PVog} *$ pal' $)>\mathrm{H}$ bogyó 'berry'. The final -ó should be a $\operatorname{dim}$ suff [diminutive suffix], but the $/ \mathrm{l} />/ \mathrm{l} />/ \mathrm{y} />/ \mathrm{j} /{ }^{1}$ is unmotivated.

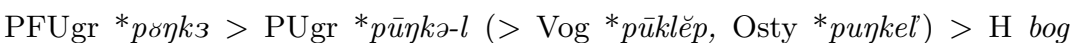

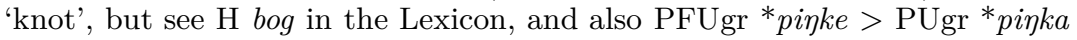

1 The authors employed Turkological transcription conventions to represent Uralic (including Hungarian) data, too. This may lead to potential problems: (1) I do not know what sound value is represented by $\check{\jmath}$ in the series " $/ \mathrm{l} />/ \mathrm{l} />/ \mathrm{y} />/ \check{\mathrm{j}} /$; as far as I can tell, this should be $\check{3}$ but on the basis of the $g y$ of $\mathrm{H}$ bogyó 'berry' I suspect it is $\check{3} ;$ (2) within the historical phonology of Vogul, I have not come across the symbol $\ddot{\ddot{a}}$ as in "PVog *pääk3". 


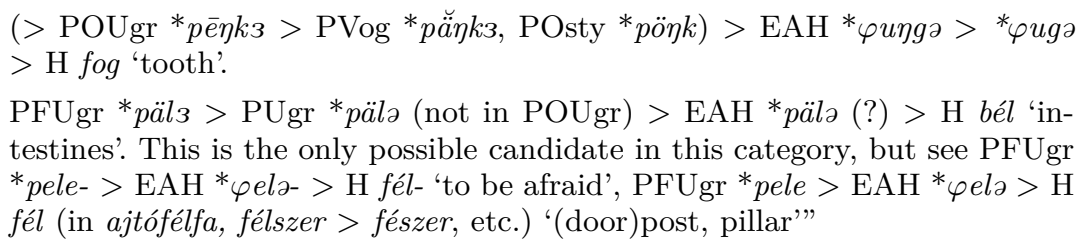

Bárczi $(1947 \mathrm{a}, 83 ; 1947 \mathrm{~b}, 4 ; 1953,110 ; 1958,113)$ accounted for the variation in the sound changes $\mathrm{U} / \mathrm{FU} / \mathrm{Ug}{ }^{*} p->f-\sim b$ - and ${ }^{*} t->t$ - $\sim d$ - by Proto-Hungarian dialect differences. Lakó had good reason to dismiss this assumption: "I find a language or dialect slightly strange if it is inclined to voicing but it only voices word-initial $p$ and $t$ to the exclusion of initial $k$. Or is it the case that instances of the voicing of $k$ have all been lost from Hungarian subsequently?" (Lakó 1962, 58; translated from the Hungarian original). He adds as an explanation that after Hungarian became an independent language, "word internal voiced stops may have exerted an assimilatory influence on the word initial voiceless stops, that is: $b, d$, and $g$ already known in word internal position may have penetrated the word initial position in certain cases already before denasalisation" (op.cit., 66; translated from the Hungarian original). My remarks on Lakó's explanation are as follows:

1. by denasalisation, he means the changes ${ }^{*} m p\left(>{ }^{*} m b\right)>b,{ }^{*} n t$ $\left(>^{*} n d\right)>d$, and ${ }^{*} \eta k\left(>{ }^{*} \eta g\right)>g$, proceeding via partial (voice) assimilation;

2. word initial $g$ - is of course out of the question since no Hungarian reflexes of $\mathrm{U} / \mathrm{FU} / \mathrm{Ug} * k$-initial words have $g$-, as Lakó himself states;

3. and finally, pace Lakó, $g$ cannot have penetrated the word initial position prior to denasalisation since old (U/FU/Ug-based) Hungarian words do not exhibit $g$-.

Lakó invariably explained the voicing of the initial consonant by the influence of the word internal voiced consonant, giving $\mathrm{H}$ dug 'stecken' (<

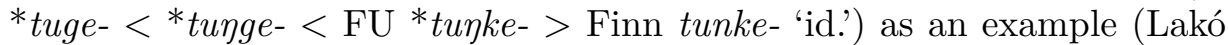
$1962,66)$. He also mentioned (ibid., 66-67) that ${ }^{*} p$ - $>b-,{ }^{*} t->d$ - type voicing also occurred in several Hungarian words due to the partial assimilatory effect of word internal ${ }^{*} r$ and ${ }^{*}$ l, e.g., H bör 'Haut, Leder' $\sim$ Osty pĕr 'rötliche Haut auf der Innerseite der Birkenrinde' ( $<$ * pers 'Haut, Rinde' U; UEW 1, 374), H daru 'Kranich' Osty V tar $\partial \gamma$ 'id.' (<*tar3-k3 [or ${ }^{*} \boldsymbol{t a r k}$ 3] 'Kranich' FU; UEW 1, 513). ${ }^{2}$ According to E. Abaffy, ${ }^{*} p$ - $>\mathrm{H} b$ -

\footnotetext{
${ }^{2}$ In accordance with the practice followed in UEW, I indicate the reconstructed
} 
was due to sporadic voicing. It is my suspicion that it is exactly the small collection of instances in which Hungarian pairs of words are involved that gives a motivation to Hungarian reflexes, as opposed to Róna-Tas' claim, as stated by E. Abaffy:
"[...] We agree with Lakó that these are voiced due to the assimilatory ef- fect of voiced consonants later in the word (Lakó: NyK. 64: 61-7 [= Lakó 1962, 61-67]): H bal 'left', bog 'knot', bör 'skin', bél 'bowels', etc., but if we think of words of ancient origin like fal 'wall', fal 'devour' along with bal; fog 'tooth', fog 'grasp' along with bog; fér 'find place' and fér(eg) 'worm' along with bör, or fel 'up' and fél 'be afraid' along with bél, it is not difficult to imagine that the danger of triple homonymy also helped voicing to take place." (E. Abaffy 1991, 29-30, translated from the Hungarian original)

This gives us the required motivation, at least in part, cf. $\mathrm{H} \boldsymbol{b}$ og 'knot' $\sim \boldsymbol{f} o g$ 'tooth', $\boldsymbol{f} \circ g$ - 'grasp'; bél 'bowels' $\sim \boldsymbol{f} e ́ l$ 'half', $\boldsymbol{f}$ él- 'be afraid'; bal 'left' $\sim \boldsymbol{f} a l$ 'wall', $\boldsymbol{f} a l$ - 'devour'; that is, I take homonymy avoidance to be the reason for voicing in these words - I have to add, though, that the $\mathrm{U} / \mathrm{FU} / \mathrm{Ug}$ word stock reconstructed by UEW is obviously a mere fraction of the total word stock of the time, hence it is possible that similar "danger of homonymy" may have obtained for bogyó 'berry', too. An important chronological observation made by E. Abaffy is the following:

\footnotetext{
"as far as the change * $p$ - $>f$ - ( $f a l$ 'wall', $f a$ 'tree', fiú 'boy', fej 'head', etc.) and the sporadic voicing ${ }^{*} p$ - $>b$ - (bal 'left', bog 'knot', bör 'skin', etc., cf. Lakó NyK. LXIV , 64) is concerned, ${ }^{*} p$ - $>b$ - must have preceded the spirantisation ${ }^{*} p$ - $>f$-, given that only $p$-, rather than $f$-, may have undergone voicing into $b$. Accordingly, we take ${ }^{*} p->b$ - to have taken place in an earlier phase of the Ancient Hungarian period, and ${ }^{*} p$ - $>f$ - to have occurred in a later phase of the same era." (E. Abaffy 1994, 13, translated from the Hungarian original)
}

I have to add here that the change ${ }^{*} p$ - $>f$ - must have taken place as a series of changes ${ }^{*} p$ - $>{ }^{*} \varphi$ - $>f$-, as indicated by Róna-Tas' examples like FU * pele- > EAH * ${ }^{*}$ ela- > H fél- 'be afraid', FU *pele > EAH * ${ }^{*}$ ela > H fél 'half' (Róna-Tas \& Berta 2011b, 1016). ${ }^{3}$ This, in fact, is in perfect harmony with the spirantisation that the other two relevant consonants underwent in Hungarian: ${ }^{*}-t->{ }^{*} \delta_{-}>z_{--},{ }^{*} k_{{ }^{-}-}>{ }^{*} \chi{ }^{\prime-}>h{ }^{-}$.

base forms of indisputable etymologies and their protolanguage labels in bold when they are first mentioned. Also, for ease of reference, the same will be done to the Hungarian members of the individual entries. I usually restrict glosses to base forms, to save space.

${ }^{3}$ For the sake of historiographic fidelity, let me add here that Klára Korompay (p.c.) has reminded me that during her university studies she had learned of the sound change "*p- $>f_{-} "$ as taking the course "*p- $>*^{*} \varphi->f_{-} "$. 
H bog 'knot, bend' is taken to be "of possible T origin" by Róna-Tas \& Berta (2011a, 138); the argument goes as follows:
"H bog was long considered to be of FUgr origin and has been connected with FUgr ${ }^{*} p ø \eta з$. [...] The fact that a $b$ - is present instead of the expected initial $f$ - was explained by the ad hoc claim that the $p$ - was voiced before $g<{ }^{*} \eta k$, hence was preserved and did not become an $f$-. This claim, however, involves several difficulties. In the case of $\mathrm{H}$ fog 'tooth' ( $<{ }^{*}$ pine $)$, fog- 'to catch'

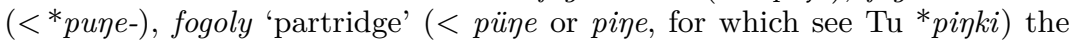 ${ }^{*} p$ - $>>f$ - change occurred before $-g$. [...] There are also semantic problems. The FUgr word has the meaning 'Knollen, Beule, Unebenheit' (Rédei 1986- 1991/1: 404 [= UEW 1, 404]) and the semantic field is 'something small and round'; see in Finn punka 'kleiner, korpulenter, dicker Mensch', Osty puฑkĕl 'festgebackener Schnee etc.', while $\mathrm{H}$ bog is connected with 'to tie' (see H bogoz- 'to tie knots'). The final $-g$ of bog in the case of the suggested $\mathrm{T}$ origin of the $\mathrm{H}$ word is problematic. The final $\mathrm{T}-g$ disappeared in most cases, and even in one case in a monosyllabic word. [...]" (op.cit., 139-140)

I disagree with the contents of this citation: (1) The change ${ }^{*} p$ - $>b$ taking place due to the assimilatory effect of the word internal voiced consonant can hardly be taken as an ad hoc explanation: it is phonetically plausible and corroborated by a number of similar cases. (2) I can see no semantic problem whatsoever; one of the examples given, Finnish punka 'kleiner, korpulenter, dicker Mensch' is obviously a secondary meaning, cf. Estonian pung 'Hervorragendes, Rundliches (Knolle, Knospe, Knauf, Knopf, Beule etc.)'; practically the same conclusion is suggested by the full Ostyak data set given in UEW: Trj puykal 'festgebackener Schnee...',

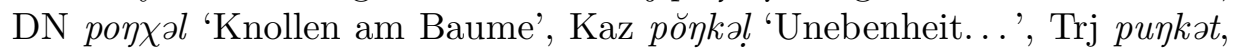

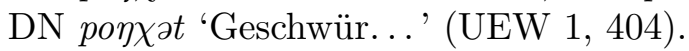

Turkic origin of $\mathrm{H} d u g(<\mathrm{FU} *$ turke-) is taken by Róna-Tas to be more probable: "DUG [dug] 'to squeeze, to thrust into' [...] dug- $<{ }^{*} d \ddot{g} g$ $<\mathrm{WOT}{ }^{*}$ dïg-, ${ }^{*} t i k_{-} \mid$EOT tik- 'to thrust, to squeeze'. [New paragaraph] Of debated T origin" (Róna-Tas \& Berta 2011a, 303); and:

\footnotetext{
"The word $d u g$ - may be related either to PFUgr *turke- or less probably to $\mathrm{T}$

*tikk-. FUgr *tunke- 'eindringen, stopfen' is present in Finn tunke-, Est tungi, MordE, MordM tongo-, perhaps in Vog TJP tokr-, KUSo to $r$ - 'stopfen'. [...] The only problem with the FUgr etymology is the initial $d$-. According to Rédei $[\ldots]$, the $d$ - evolved under the influence of the following $/ \mathrm{g} /$. This did not occur in the case of $\mathrm{H}$ tegez 'quiver' < PUgr *täggät. Rédei also mentioned $\mathrm{T}$ tïg-. The problematic part of the $\mathrm{T}$ etymology is the final $/ \mathrm{g} /$. If the dial[ectal] forms with $-k[\ldots]$ preserved a more arch[aic] form [...], then the $\mathrm{T}$ etymology becomes more likely" (op.cit., 305-306)
}

The Turkic word is indeed close to the Hungarian word both in sound and in meaning, but all I can imagine is that the Turkic word may have 
reinforced the change ${ }^{*} t-{ }^{*} d$ - just happening or having happened in the Ancient Hungarian verb. The $t$ - in H tegez (< Ug ${ }^{*} \boldsymbol{t a ̈ y 3 - t 3 ~ ' i d . ' ; ~ U E W ~ 2 , ~}$ 894) can hardly be an argument against the FU origin of $d u g$, given that sound changes are often less than "sound laws"; usually they are mere "tendencies of sound change". 4

In sum, I think that the change a ${ }^{*} p$ - $>f-\sim b$-, ${ }^{*} t->t$ - $\sim d$ - can be attributed to the following reasons:

1. an attempt to avoid homonymy, as can be clearly seen in the set of words with initial $*^{*}$ - $(>b$ - $)$,

2. a partial assimilatory effect of the word internal voiced consonant; in the group of words with initial ${ }^{*} t$ - $(>d$-) this may have been the only effect,

3. perhaps, at least in one case (dug), the effect of a word of similar sound and meaning from a foreign language in contact with Hungarian: $\mathrm{H}$ $d u g \leftarrow$ Western Old Turkic *dïg-.

As opposed to ${ }^{*} p$ - $>b$ - and ${ }^{*} t$ - $>d$-, there was no sound change of word initial $\mathrm{U} / \mathrm{FU} / \mathrm{Ug}{ }^{*} k$ - into $\mathrm{H} g$-, but as far as I can see there simply cannot have been such a change for the following reason: ${ }^{*} k \delta$ - invariably turned into $h r$ - in Hungarian, whereas ${ }^{*} k \ddot{\delta}$ - invariably remained $k \ddot{\delta}$ - (disregarding individual secondary developments of an assimilatory kind like ${ }^{*} k{ }^{-}->^{*} \chi_{\varnothing}-$ $>h \gamma_{-}>h \ddot{-}$ - in H hös 'Held', going back to $\mathbf{U} * \boldsymbol{k} \boldsymbol{a} \boldsymbol{c} \boldsymbol{a} \boldsymbol{a}$ 'junger, unverheirateter Mann'; UEW 1, 110), as confirmed by Hungarian reflexes of protolanguage $*_{k}$ - and ${ }^{*} k \ddot{\delta}$ - sequences, e.g.,

*kol- (e.g., H hal 'fish' < U *kala 'Fisch'; UEW 1, 119),

*kor- (e.g., H három 'three' < Ug *krrзm3 $\lesssim \mathrm{Ug} * k z l 3 m_{3}$

$<$ FU * kolme 'drei'; UEW 1, 174),

*krmp- (e.g., H hab 'scum' < U * kumpa 'Welle'; UEW 1, 203),

*kont- (e.g., H had 'army' < FU, ?U *kunta 'Geschlecht, Sippe, Gemeinschaft'; UEW 1, 206),

*krøk- (e.g., H hág 'mount (vb)' < ?FU, Ug *kay3- [Ug *kagyk3-]'klettern, steigen'; UEW 1, 127),

and, respectively,

${ }^{4}$ By the way: the Ugric forerunner of $\mathrm{H}$ tegez can only be reconstructed in the form ${ }^{*}$ täns-t3 (as in UEW) as opposed to *tängät, given that short U/FU/Ug *-t- only turned into $z$ in Hungarian in an intervocalic position. 
*köl- (e.g., H kel 'rise' < FU *kä̈lä- 'waten'; UEW 1: 133-134),

*kör- (e.g., H kéreg 'rind' < FU *kere 'Rinde', UEW 1: 148-149),

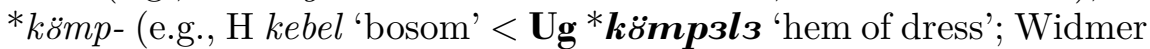
2007, 146-149),

*könt- (e.g., H kedv 'inclination' < Ug *k könt3 'Laune, Stimmung';

UEW 2, 861-862).

In the past few decades, it was primarily researchers of the history of Hungarian (e.g., Géza Bárczi, Erzsébet E. Abaffy) who claimed that, in several cases, either the sequence $\mathrm{U} / \mathrm{FU} / \mathrm{Ug}{ }^{*} k_{r-}(>\mathrm{H} k{ }-)$ was preserved or it occurs as an instance of regression. For instance, in the following pairs of words, $k \varnothing$ - and $h \Varangle$ - would both occur in parallel: hajol 'bend oneself', hajlik 'bend' (< Ug *kaj3- '(sich) beugen'; UEW 2, 854) kajla 'droopy', kajsza 'crumpled' (these are not mentioned in UEW and dismissed in MSzFE 2, 249), huny 'close the eyes' ( $<$ U * $\boldsymbol{k} \boldsymbol{\text { unńa }}$ - 'die Augen schließen, blinzeln'; UEW 1, 208-209) dialectal kum (not mentioned UEW, dismissed in MSzFE 2, 309-310). I would take the preservation of $\mathrm{U} / \mathrm{FU} / \mathrm{Ug} * k r->\mathrm{H}$ $k r$ - to be strange (if at all possible) since the emergence of the two Hungarian reflexes $\left(h r_{-}, k \ddot{8}-\right)$ of ${ }^{*} k$ - can be traced back to Proto-Ugric. Lakó dismissed the alternative sound changes $\mathrm{U} / \mathrm{FU} / \mathrm{Ug}{ }^{*} p$ - $>f-\sim b$ - and ${ }^{*} t->$ $t$ - $\sim d$ - in various Hungarian dialects on the basis that it did not happen in the case of ${ }^{*} k$-, that is, there was no ${ }^{*} k$ - $>k^{-} \sim^{*} g$ - phoneme split across dialects. I think this would have been unexpected since certain combinatory variants would have had further potential combinatory variants (that

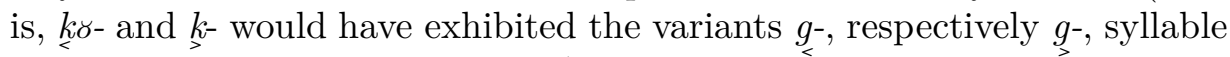
finally before a voiced consonant); furthermore, Ob-Ugric languages are also consistent in the differential reflexes of former ${ }^{*} k \delta$ - and ${ }^{*} k \ddot{\delta}$-, that is, the Proto-Ugric phoneme ${ }^{*} k$ - will have had two allophones only. An-

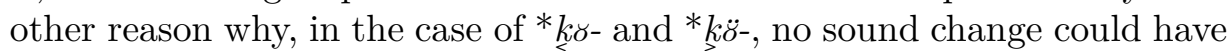

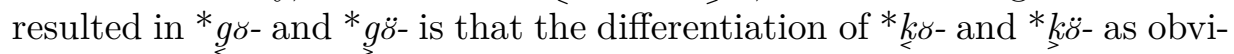
ous combinatory variants occurred as early as in PUg, and it would hardly

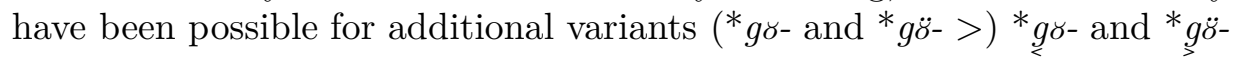
to emerge, as it would have meant the simultaneous existence of four-way combinatory variation. I wonder if this has ever happened in the history of any language. These four variants could have become phonemicised later in (various dialects of) the Ugric languages, but even the slightest traces of this cannot be found. On the other hand, the difference between *kroand $*_{k} \ddot{z}-$ did indeed undergo phonemicisation in Hungarian and certain Ob-Ugric dialects. In Vogul and Ostyak, these are (nearly) always distinct, even if not necessarily contrastive: in most Vogul dialects we find 


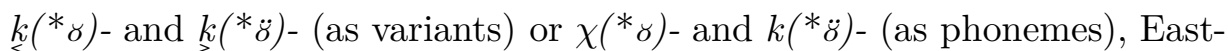
ern Ostyak dialects have $k\left(*^{*}\right)$ - and $k\left({ }^{*} \ddot{z}\right)$ - (as variants), and Western ones have $\chi\left(*_{\varnothing}\right)$ - and $k\left(*^{*}\right)$ - (as phonemes).

To summarise the foregoing: I think, in accordance with Erzsébet E. Abaffy's view, that the explanation of the dual reflexes of PU/PFU/PUg ${ }^{*} p$ - and ${ }^{*} t$ - (that is: ${ }^{*} p$ - $>f_{-} \sim b_{-},{ }^{*} t->t$ - $\sim d$-) resides in two factors:

- first, the word internal (primary or secondary) voiced consonant triggered partial assimilation (voicing) of the initial consonant,

- second, and subsequently, due to an effort to eliminate homonymy, the closest congener of the initial consonant (that is, its voiced counterpart) replaced the original voiceless stop.

Of course, the assumption of homonymy avoidance is not an absolutely satisfactory explanation, as languages tend to abound in instances of homonymy. The celebrated Hungarian four-way homonymy of ár 'price', ár 'flood', ár 'awl', and ár 'are (unit of area measurement)' is a piece of conclusive evidence of the fact that languages do tolerate such disturbing phenomena even to an extreme degree; on the other hand, note that the last two words of the four have become more or less peripheral by today.

In the case of the verb $d u g$, the effect of a Western Old Turkish verb of similar sound and meaning (*dig-, but: $\left.{ }^{*} t i k-!\right)$ may have had a role as well.

\section{Interdental spirants in the early history of Hungarian}

2.1. I discussed this issue as many as three times before (Honti 1992; 2001; 2004), but I found it necessary to reconsider it, for several reasons. First, I had to revise some of my earlier ideas; second, certain misprints had to be corrected; third, these papers were published in less readily accessible places (mostly in Festschrifts); and fourth, in section 3 of the present paper, I refer (and rely) on some of the results presented here.

2.1.1. In H velö 'marrow' $\sim$ Osty weləm $\sim$ Zyr vem $\sim$ Lp $\hat{a} d \hat{a} \sim$ Finn ydin (ytime-) and H hagy- 'let' $\sim$ Osty kăj- $\sim$ Zyr kol- $\sim$ Lp guodde- $\sim$ Finn katoa-, etc., we find correspondences of word-internal Ugric-Permian $l \sim$ Finnic-Volgaic (excluding Lapp) $t$, Lapp $\delta$, and Ugric-Permian $* l$ $(>l$, and, among others, $\mathrm{H} g y$, Osty $j$, Permian $j, \emptyset) \sim$ Finnic-Volgaic (excluding Lapp) $t$, Lapp $\delta$ in etymologically clearly related words. As the PFU predecessor of such consonant correspondences, Genetz assumed a $d(\delta)$-like sound: "[...] For Proto-Finno-Ugric, we must assume a peculiar 
consonant resembling Finnish $d, l$, and $r[\ldots]$. This sound was not dental in the strict sense, it was alveolar like the spirant in today's Western Finnish dialects, or perhaps a bilateral stop like $d$ in the Surgut dialect, or $t$ in the Northern dialect, of Ostyak" (Genetz 1896, 11; translated from the Finnish original). Setälä's paper was written and published at roughly the same time; in it, his results are akin to Genetz's explanation of the PFU forerunners of word-internal consonant correspondences in etymologies of the above kind: "[...] they must have been spirants. The voiced spirant $d(\delta)$ exists even today in the Lapp spoken in Finland [... It must have been] a voiced dental spirant, that is, something like $\delta$ [...]." (Setälä 1896, 417; translated from the Hungarian original). Unlike Genetz, Setälä also took it to be an important fact that, in part of the words at hand, some languages (Ugric and Permic) exhibited palatalised consonants, and he projected that duality back to the protolanguage, that is, he reconstructed $\mathrm{a} * \delta$ in addition to $* \delta$ (op.cit., 418-419).

For a long time, researchers left this problem alone, accepting Setälä's view. Quite some time later, Steinitz appeared to have become sceptical, and since then, these two consonants can be seen as debated units of $\mathrm{PU} / \mathrm{PFU}$. Steinitz noted, first, that $\delta$ as a phoneme is unprecedented in today's Finno-Ugric languages, and second, that postulating $* \delta$ and $* \delta$ is problematic with respect to the Volgaic languages (but he did not go into details on that point). Then he added: "Eigenartig erscheint auch die Stellung derartiger Spiranten im fiugr. Konsonantensystem"5 (Steinitz 1952, 37).

Décsy (1969b) proposed that Setälä's reconstructed consonants had no place in the phoneme system of the protolanguage. It is especially $* \delta$ that he dismissed as arbitrary and absurd: Setälä had wanted to summarise all important features of the daughter-language continuations of the alleged * ${ }^{\prime}$ in a single symbol ("Verlegenheitslösung von Setälä" [Setälä's embarrassment solution], as Décsy [op.cit., 64] put it). His objection to reconstructing sounds like $\delta$ was of a theoretical nature: "Das $\delta$ ist ein merkmalhaftiger Konsonant, es ist die stimmhafte Entsprechung zum $\vartheta$. Nach dem Prinzip [...] kann kein merkmalhaftiges Phonem ohne seinen merkmallosen Gegensatz in einem System vorhanden sein [...]. Das gleiche gilt, nur in verstärktem Maße, auch für das $\delta$, das zweifache Merkmalhaftigkeit aufweist: es ist nicht nur stimmhaft, sondern auch palatal" ${ }^{6}$ (Décsy

5 "The status of such spirants in the Finno-Ugric consonant system seems to be peculiar."

6 " $\delta$ is a marked consonant, the voiced counterpart of $\vartheta$. As a matter of principle... no marked phoneme can be present in a system without its unmarked counterpart 
1969a, 201). (Perhaps Steinitz's tacit objections were of a similar kind.) Simultaneously with dismissing $* \delta$ and $* \delta$, Décsy offered a solution for the sound correspondences in H velo" 'marrow' Finn ydin 'id.', H hagy- 'let' $\sim$ Finn katoa- 'disappear', etc.: he claimed that the protolanguage had alternations of $t \sim l, t \sim l$ in ancient words like these (Décsy 1969b, 64-66). With that - at least in Décsy's view - the perfect solution was available, making further etymological correspondences possible to explore: "Durch die Annahme eines $\delta$ oder $\delta$ wird hier nichts erklärt, durch den Wechsel $t \sim l$ oder $t \sim l$ bleibt dagegen keine Frage ungelöst. Bei einer Ausnahme [=Annahme?, L. H.] des Wechsels $t \sim l$ (und des vokalharmonischen Parallelismus) können z. B. auch ung. tüze- 'Feuer' $(<* t i t a)$ und fi. tuli 'ds.' (<tula) miteinander etymologisch verknüpft werden"7 (ibid., 65-66). Former existence of the alternations ${ }^{*} t \sim{ }^{*} l$ and ${ }^{*} t \sim{ }^{*} l$ could mean that in words of $\mathrm{U} / \mathrm{FU}$ origin there could be correspondences like Finnish $t \sim$ $\mathrm{H} l$ and Finnish $l \sim \mathrm{H} t$ at will. The alternation $t \sim l$ would be especially strange. This view of Décsy's could at most be acceptable as belonging to the category of science fiction...

Rédei, too, found this solution less than satisfactory: " $* \delta$ and $* \delta$ are among the most contested consonants of the protolanguage [...]. Several authors say they should be seen as abstract symbols for indeterminate consonants rather than those of sounds that used to actually exist" (Rédei 1976, 259; translated from the Hungarian original). However, Rédei did not say who were the authors using these symbols for want of a better solution; also the Uralisches Etymologisches Wörterbuch (compiled under his supervision) contains these symbols in the reconstructed protolanguage forms of all etymologies in which they had been assumed ever since Genetz and Setälä.

Décsy's idea was modified by Kazantsev (1990) in a way that, instead of the alternations (indeed unjustified and unjustifiable), he postulated the protolanguage consonants $* l$ and $* l$, explaining the reflexes $t(d$ and $\delta$ ) by word-internal assimilation and dissimilation. Thus, he reconstructed the

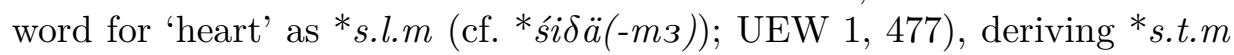
from it in Finnic-Volgaic languages. Kazantsev took $l>t$ to be an instance of assimilation since both ${ }^{*} s$ and $t$ are voiceless, and also one of

being also present [...] The same applies, even more seriously, to $\delta$, exhibiting double markedness: it is not only voiced but also palatal."

7 "Nothing can be explained by positing $\delta$ or $\delta$, while assuming the alternations $t$ $\sim l$ or $t \sim l$ no question remains unanswered. With the exception [assumption?, L.H.] of the alternation $t \sim l$ (and vowel harmony parallelism) we can establish a link between H tüz 'fire' (< *tita) and Finnish tuli 'id.' $(<$ tula)." 
dissimilation since both $l$ and $m$ are sonorants, unlike $t$ (op.cit., 184). One of the important features of the changes he assumed was invariably devoicing. This proposal does not lead anywhere: (a) it predicts absolutely arbitrary associative sound changes to be possible (nearly any two consonants will exhibit identical and non-identical features on the basis of which we could expect assimilation and/or dissimilation to take place), (b) if $l$ is devoiced, it would yield $L$ rather than $t,(\mathrm{c})$ if there really had been a tendency like this in the Finnic-Volgaic protolanguage, the process would have been expected to carry on after the separation of individual languages (Cheremiss, Mordvin, Lapp, Finnic): a development that shows no trace of having happened, and (d) this strange change involved just a few words even though we know relatively many in which it could have taken place (e.g., Finnish sula 'melted', silmä 'eye'). Kazantsev's idea can be evaluated similarly to Décsy's.

However, Décsy's theoretical objections to $* \delta$ and $* \delta$ were justified, and others seemed to share his doubts: "Synchronically the status of the 'spirants' $* \delta$ and $* \delta$ appears to be problematic. These phonemes may have originally been related to either the dental stop or the liquids" (Janhunen $1982,24)$. In other places, he gave these reconstructed segments as *d and ${ }^{*} d$ (with respect to this way of symbolising them, cf. already Itkonen $1956 \mathrm{~b}, 70)$, but this is not more than a technical solution, given that he referred to these segments, in inverted commas, as "Dentalspiranten" (Janhunen 1981, 32); a hybrid solution that was just as disturbing as the other one.

Sammallahti started by reconstructing $* \delta$ and $* \delta$ with no reservation (Sammallahti 1979, 24), later on, he took over Janhunen's symbols but he noted "The phonemes /d/ and /d'/ were probably spirants" (Sammallahti 1988, 482).

Hajdú also had reservations with respect to the protolanguage existence of these sounds: in his table of PU/PFU phonemes, he included them (and $\gamma$ ) in parentheses, given that several authors had expressed doubts concerning the justification of their reconstruction (Hajdú 1987, 184). But he did not advance any suggestions as to the solution of the problem. What is more, in reconstructing protolanguage lexemes, he used the traditional symbols he had previously objected to, e.g., U *'si * $\left.{ }^{*} i \delta e-m e !\right)$.

Arguing against Décsy, Itkonen pointed out that the sound correspondences in the relevant etymologies could only be explained by positing $* \delta$ and $* \delta$ (Itkonen 1969, 110-111; cf. also Itkonen 1956a, 618-619). More recently, Korhonen argued for retaining $* \delta$ and $* \delta$, saying that simply be- 
cause of their strong markedness ("Merkmalhaftigkeit") they need not be deleted from the protolanguage system (Korhonen 1990, 170-171).

2.1.2. In what follows, I will advance a suggestion that I hope will take us closer to the solution. I think we can go back to Genetz's idea that the original sound may have been a lateral spirant like Ostyak $\Lambda$ (=Genetz's $d, t)$. Assuming $*_{\Lambda}$ instead of $* \delta$ and $*_{\Lambda}^{*}$ instead of $*^{\prime} \delta$, we can count on developments in most Uralic languages that are similar to those in the case of Proto-Ostyak $*_{\Lambda}\left(*_{\Lambda}>\right.$ Sur Kaz $\Lambda$, VVj Ber O $l$, Sal Irt Ni Šer $t, \mathrm{Vj}$ $j$ - $\sim \emptyset$-; for the details, see Honti 1980, 22, 24). In Permic languages, these merged with the corresponding voiced laterals. In Ugric languages, on the other hand, such (partial) merger must have been a separate linguistic event. This is suggested by the Ostyak reflexes, themselves being separate developments, e.g., Osty V jom 'Ahlkirsche' Vog T lèm, Finn tuomi < U *iéme (*'́eme UEW 1, 65), Osty V söj 'Kohle' 〜 Vog T sülì, Finn sysi $<\mathrm{U} *$ śińe (*śíe UEW 1, 477). Thus

a. U/FU $*^{*} \times * \check{s}>\mathrm{Ug}^{*} \vartheta>>$ Ob-Ugric $* \vartheta>$ Proto-Ostyak $*_{\Lambda}$, Proto$\operatorname{Vogul} * t$,

b. U/FU/Ug $*_{\Lambda}>>$ Ob-Ugric $*_{\Lambda}>>$ Proto-Ostyak $*_{\Lambda}$ (> Osty VVj Ber O -l-, Sur Kaz - - -, Irt Ni Šur -t-; V Ber O l-, Sur Kaz $\Lambda_{-}^{-}$, Irt Ni Sur $t-, \operatorname{Vj} j-, \not-) \sim$ Proto-Vogul $* l$,

c. U/FU $*_{i}^{\prime}>\mathrm{Ug} *_{i}^{\prime}>$ Ob-Ugric $*_{i}^{\prime}>$ Proto-Ostyak $*_{j} \sim$ Proto-Vogul $*$ ?. In Finnic-Volgaic, ${ }^{*}$ í was depalatalised.

In the Volgaic languages, initial $*_{\Lambda}$ merged with $* l$ and its word internal instances merged with ${ }^{*} t$; whereas in Finnic, due to depalatalisation, it always merged with ${ }^{*} t$. After depalatalisation in Lapp, initial $*_{\Lambda}$ turned into ${ }^{*} t$, while in word internal position, the constriction shifted from the lateral to the interdental region: $*_{\Lambda}>\delta$. In Samoyedic, the changes $*_{\Lambda}>$ ${ }^{*} r, *_{\Lambda}^{\prime}>*_{j}$ occurred (cf. Sammallahti 1988, 485).

There is a single example of initial $*_{\Lambda}$ (which is identical to traditional

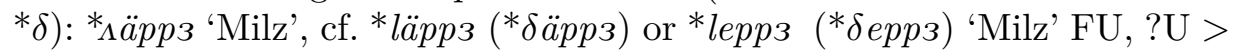
?Lp N dad've -đv-, daw'de 'milt', L tab'te 'Milz', Cher lepə, Voty lup, Zyr lop, ?Osty «epatne, H lép, ?Yur rapśā, ıapśa (UEW 1, 242). According to UEW, the Lapp word can only be seen as belonging here if the protolanguage had initial $* \delta$, even though this would be the single occurrence of this segment, and only "wenn das $\delta(<* \delta \ddot{a})$ der anzunehmenden urlapp. Lautverbindung ${ }^{*} b \delta\left(<{ }^{*} p p 3 \delta \ddot{a}\right)$ ein Ableitungssuffix ist". ${ }^{8}$ It is true that

8 "if the element $\delta(<* \delta \ddot{a})$ of the probable Proto-Lapp sequence ${ }^{*} b \delta\left(<{ }^{*} p p 3 \delta \ddot{a}\right)$ is a derivational suffix"

Acta Linguistica Hungarica 60, 2013 
this initial consonant can be attested in this single word in the protolanguage; but it may well be the case that there had been more. ${ }^{9}$ It may also be the case that the present form of the Lapp word preserves a one-time derivational suffix that has no traces in any of the other languages, and hence the form $* d \ddot{a} p d \ddot{a}\left[={ }^{*} \delta \ddot{a} p \delta \ddot{a}={ }^{*}{ }_{\Lambda} \ddot{a} p \Lambda \ddot{a}\right]$ reconstructed by Sammallahti $(1988,492)$ may not be correct since, except for Lapp, no present-day reflexes can be reconstructed from the word internal cluster ${ }^{*} p d\left[={ }^{*} p \delta=\right.$ $\left.{ }^{*} p \Lambda\right]$.

Merlingen thinks that archaic languages may have had several lateral phonemes and that protolanguages may have been more archaic ("altertümlicher") than their present-day offspring (cf. Merlingen 1984; Korhonen 1990), although the latter claim is something I do not know what to do with. Merlingen (1984, 334-335) claims that Proto-Uralic also must have had phonemes like $t$ or $t t$, and this is in conformity with the assumption I have just been presenting.

Table 1: The most frequent reflexes of $*_{\Lambda}$ and $*_{\Lambda}$. "Hung." = Hungarian. (Cf. also Lakó 1968, 51, 68-70; Korhonen 1981, 129, 160.)

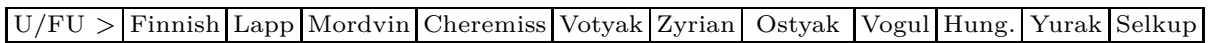

\begin{tabular}{|c|c|c|c|c|c|c|c|c|c|c|c|}
\hline$*_{\Lambda-}$ & - & $d$ & - & $l$ & $l$ & $l$ & $\begin{array}{l}*_{\Lambda}>\Lambda, \\
l, t, j, \emptyset\end{array}$ & - & $l$ & $\begin{array}{c}{ }^{*} l>r, \\
\Lambda\end{array}$ & - \\
\hline \multirow[t]{4}{*}{$*_{-\Lambda-}$} & $t$ & $d d$ & $d$ & $\check{c}$ & $l$ & $l$ & $\begin{array}{c}*_{\Lambda}>\Lambda \\
l, t\end{array}$ & $l$ & $l$ & $j$ & $t$ \\
\hline & & & & & $\emptyset$ & $\varnothing$ & $\not$ & $\emptyset$ & & $t$ & $t^{\prime}$ \\
\hline & $t$ & & & & & & & & & $r$ & $r$ \\
\hline & & & & & & & & & & & $\bar{z}$ \\
\hline \multirow[t]{2}{*}{$*_{A}^{*}-$} & $t$ & $d$ & $l$ & $l$ & $l$ & $l$ & $j$ & $l$ & - & $j$ & $\bar{t}$ \\
\hline & & $h$ & & & & & & & & & $\frac{\bar{c}}{c}$ \\
\hline \multirow[t]{2}{*}{${ }^{*}-\Lambda^{-}$} & $t$ & $d d$ & $l$ & $d$ & $l$ & $l$ & $j$ & $l$ & $g y$ & $j$ & $d^{\prime}$ \\
\hline & & & & & & & & & $i$ & & $\check{c} \check{c}$ \\
\hline
\end{tabular}

2.2. I have to add here that my earlier views concerning the Ostyak consonants $\Lambda$ and $\Lambda$ are in need of some revision. This has been made necessary by Verte's instrumental phonetic results on these consonants. ${ }^{10}$

${ }^{9}$ Cf. also the following: "If Proto-Finno-Ugric had initial $* \delta$, it may have had initial $* \delta$, too, since the palatalised consonant is marked as opposed to its non-palatalised counterpart, and thus it presupposes the existence of the corresponding unmarked consonant. It is possible that all words containing an initial $* \delta$ were later lost, as there were not too many of them to begin with, both the palatalised and the nonpalatalised interdental spirants may have been of rather low frequency" (Korhonen 1981, 129; translated from the Finnish original).

${ }^{10}$ In the interpretation of those results, a phonetician colleague, Ilona Kassai has been of utmost help. I want to express my gratitude to her.

Acta Linguistica Hungarica 60, 2013 
Earlier on, I treated Ostyak $\Lambda$ and $\hat{\Lambda}$ as voiceless lateral consonants (Honti 1984, 26). One of the decisive circumstances that made me think so was that, of the fieldworkers, Steinitz unambiguously characterised them a voiceless, ${ }^{11}$ and on the basis of others' descriptions I found this quite probable. On the other hand, when I worked with informants on Kazym and Surgut Ostyak, I perceived these sounds as voiceless, too. Karjalainen (1905, XII) described $\Lambda$ as a weakly voiced/voiceless $l$-sound. Terëškin (1981, 9-10) gave a characterisation similar to that of Karjalainen. Rédei wrote about a voiceless spirantic $l$-sound $(1968,11-22)$. Katz $(1975,71$, 88) referred to Steinitz $(1937,201 \mathrm{ff}[1980,20])$ and Rédei $(1968,11 \mathrm{ff})$ in classifying these consonants as voiceless ("+ cons", "- son"). I had several occasions to carry on conversations with Károly Rédei about these Ostyak spirantic lateral consonants. He claimed to have heard them clearly as liquids. If they are indeed liquids, they have to be voiced, of course. Karjalainen's and Terëškin's descriptions cannot be ignored, either, according to which speakers tend to pronounce them in a semi-voiced manner (in all or in some of the cases). Another relevant point is that in Karjalainen's and Paasonen's field notes they are very often symbolised as syllabic consonants if the preceding a (or a) is dropped. Surely, in such cases, they have to be sonorants (that is, phonologically voiced).

I will try to clarify the nature of these consonants on the basis of Verte $1979 ; 1985 ; 1986 ; 1989 ; 1990$; cf. Eek 1982) and in terms of Kassai's interpretation, confronting them with the features of $l$ (Karjalainen's $l$ ) where necessary. ${ }^{12}$ The reason why Verte's observations are worth quoting here is that they are (as opposed to claims made by earlier scholars) not only acoustic in nature but also based on results of instrumental examinations. Verte characterises these sounds as follows:

А: "Фонема [\&] по восприятию на слух и по экспериментальным данным отнесена к группе шумных фонем" (Verte 1979, 18). "Как показывают данные 40 денталопалатограмм, сближенне кончика и передней части язука осуществляеця со всем участком альвеол и прилегающим к нему участком лингвальной поверхности зубов (примерно 2/3), а бока языка контактируют с боковыми альвеолами. Шель, как прав-

11 “l $l(l)$ : произносиця в северной части Березовского района [...] в Шурышкарском, Сургутском и Ларьякском районах как своеобразный звук $\Lambda$ (»глухой«, »шумный« $\Lambda$ ) [...]" (" $l$ " $(l)$ : in the northern part of the Berezov district [...] in the Šryškary, Surgut, and Laryak districts it is pronounced as a peculiar $\Lambda$ consonant ('voiceless', 'noisy' $\Lambda)$ [...]") (Steinitz 1980, 64).

12 Note that Verte symbolises the consonants under discussion here in a variety of ways: $\Lambda=\&(1979), L(1985 ; 1990), l$ (1986), and $\Lambda=\lambda(1979), L^{\prime}(1985 ; 1990), l$ (1986). 
ило, монолатеральная и узкая (idem.).” “[...] анализ дентопалатограмм и слуховое восприятие позволили определить два факультативных оттенка фонемы [b] - ' $b$ ' и ' $t f$ ': ' $b$ ' - переднеязычный дентально-алвеоларный латеральный глухой; ' $t \&$ ' - переднеязычный дентальный умереннои сильнодорсальный смычнощелевой (аффриката) ${ }^{13}$ с боковой щелью глухой" (ibid., 19). ${ }^{14}$

In a later paper she writes that both $\Lambda$ and $\Lambda$ are articulated with so narrow an aperture that it can be almost perceived as contact (Verte 1985, 40); in yet another paper, she writes that these very noisy consonants can be perceived as acoustically voiced in an intervocalic position (Verte 1986, 85). Furthermore:

র́: "Оттенки фонемы $[\lambda]$ представляют собой латерально-щелевые звуки со спецификческой акустикческой окраской-мягкостью. [New paragraph] Анализ данных 10 дентопалатограмм свидетельствует о сред-

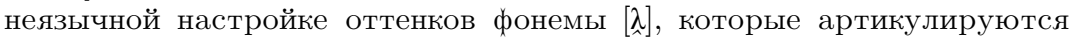
передней и средней частями спинки языка при опущенном кончика языка"15 (Verte 1979, 23-24).

$l:$ “[...] артикуляторная настройка оттенков фонемы $[l]$ определяется от слабой дорсальности с факультативной настройкой моно- и билатеральных щелей. Все реализации фонемы $[l]$ по слуховым наблюдениям невеляризованы, акустически близки к европейскому $\underset{\sim}{l}$. [New

13 Note that "affricate-like" realisations are also mentioned by Castrén: "Die Consonanten $t$ und $d[=\Lambda$; L. H.] bezeichnen zwei aspirirte Laute, von denen der eine wie $t l$ oder $t h l$, der andere wie $d l$ oder $d h l$ ausgesprochen wird" ["The consonants $t$ and $d[=\Lambda$; L. H.] stand for two aspirated sounds one of which is pronounced as $t l$ or $t h l$, and the other one as $d l$ or $d h l$ "] (Castrén 1858/1969, 6). And Terëškin expressis verbis writes about an affricate-like sound: on Surgut/Kazym " $l$ аффрикативного типа" [affricate-like $l$ ] (Terëškin 1958, 326).

$14 \Lambda$ : "The phoneme [ 6$]$ belongs to noisy phonemes both as perceived by ear and as analysed by instrumental phonetic means" (Verte 1979, 18). "As shown by data in 40 dentalopalatograms, we have the approximation [read: contact, L. H.] of the tip and corona of the tongue to the whole alveolar region and to the area of the teeth next to their lingual surface (approximately in two thirds of the relevant area), while the side of the tongue is in contact with the lateral alveolar region. The aperture is usually unilateral and narrow" (idem.). "[...] on the basis of an analysis of the dentopalatograms and aural perception, two facultative shades of the phoneme $[b]$ can be distinguished: ' $b$ ' and ' $t b$ ' : ' $b$ ' - voiceless apical dentialveolar lateral; ' $t \boldsymbol{f}$ ' - voiceless apical slightly or strongly dorsal affricate with lateral aperture" (ibid., 19).

15 "Variants of the phoneme $[\lambda]$ appear as palatalised lateral approximants of a special acoustic shade. [New paragraph] The 10 dentopalatograms at our disposal witness a central articulation of variants of the phoneme $[\lambda]$ that are produced by the frontal and central areas of the tongue dorsum, with a lowered apex."

Acta Linguistica Hungarica 60, 2013 
paragraph] По данным 110 п[алат]ограмм на [l] было выявлено, что фонема проявляется в основном в сонантных оттенках ' $l$ ', a также в слабозвонких ' $l$ ', финальноглухих ' $l f$ ' (перед глухими согласными), инициальноглухих ' $b l$ ' (после глухих согласных и в оттенках) 'll’’"16 (ibid., 15-16).

From these observations, Verte came to the following conclusions:

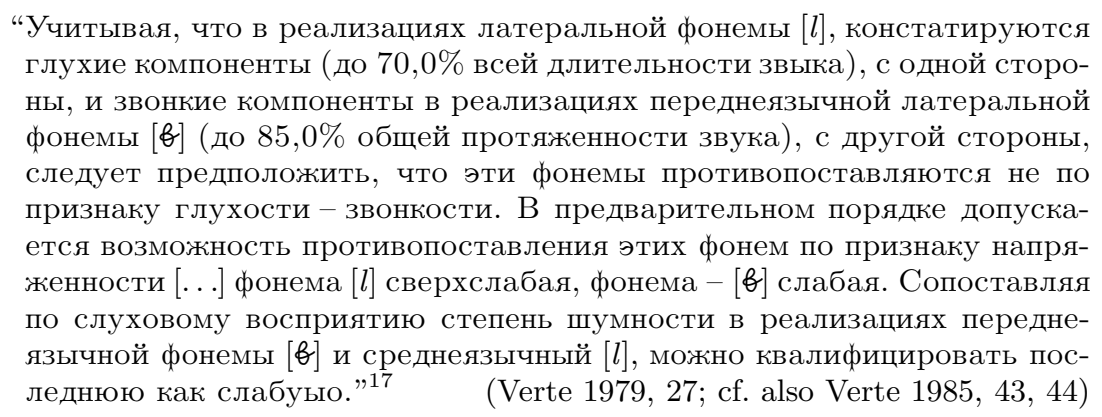

As I was informed by Ilona Kassai (p.c.), it follows from Verte's description (stating that the articulation of $\Lambda$ and $\Lambda$ exhibits great variety in both the size and the place of the constriction) that voicing, being of lower frequency, is suppressed by the noise produced in the lateral aperture. The notion of semi-voicedness or voicelessness is perhaps only due to the narrow lateral aperture and the noise produced in it. With the elision of a

${ }^{16} l$ : "[ . . ] the articulatory character of varieties of the phoneme $[l]$ is dorsal, between week and strong dorsal nature, with an optional addition of mono- or bilateral aperture. All realisations of the phoneme $[l]$ are non-velarised as per aural perception, and acoustically they are close to the European phoneme $\underset{\sim}{l}$. [New paragraph] On the basis of 110 palatograms of $[l]$ it turned out that the phoneme is basically realised as sonorant versions of ' $l$ ', its weakly voiced versions, (before voiceless consonants) as voiceless in its last phase, (after voiceless consonants) as voiceless ' $b$ l' or 'll ' in its initial portion."

17 "Taking into consideration the facts that, first, voiceless components can be observed in the realisations of the lateral phoneme $[l]$ (up to $70 \%$ of the full duration of the sound), and, second, voiced components occur in the realisations of the realisations of the coronal lateral phoneme [ 6 ] (up to $85 \%$ of the full duration of the sound), we have to assume that these phonemes do not participate in the voicedvoiceless opposition. For the time being, we can conjecture that these phonemes are in opposition with respect to tenseness [...] the phoneme $[l]$ is very weakly tense, while the phoneme $[\&]$ is weakly so. If we compare the auditorily perceptible degree of voicing of the coronal phoneme $[\&]$ and the mediodorsal phoneme $[l]$, that of the latter proves to be weak."

Acta Linguistica Hungarica 60, 2013 
(and $\hat{\jmath}$ ), these consonants can nevertheless become syllabic as they surpass their environment in sonority, just like Hungarian $[\mathrm{s}]$ in the interjection pszt 'hush'. In phonological terms, then, the Ostyak consonants at hand are to be classified as voiced.

Both $l$-type and $\Lambda$-type sounds are lateral. In the case of $l$-type sounds, air passes through a wide aperture at the sides of the tongue, while in $\Lambda$-type ones a strong hissing noise is produced (they are, in other words, "strident" consonants). The latter cannot be taken to be liquids in terms of the relevant phonetic descriptions (though in Finno-Ugric studies they are traditionally referred to as "voiceless liquids").

2.3. This proposal of mine raises yet another problem. Would it not be possible for $* \vartheta$ to support the one-time existence of $* \delta$ and $* \delta$, reconstructed by many scholars for the protolanguage, given that, at least with respect to ${ }^{*} \delta$, we would then have the voiceless term of the "voiced-voiceless" opposition $\vartheta \leftrightarrow \delta$ ? I think I have two arguments against that, the first being rather inconclusive, but the second one deserving serious consideration.

(a) Even if there was an opposition $\vartheta \leftrightarrow \delta$, I do not know of any family of words for which we could reconstruct $\vartheta$, that is, one that could support the existence of an opposition of $\vartheta \leftrightarrow \delta$. Of course, such an opposition might have existed, since $\vartheta$ would have been a very strongly marked phoneme, and would therefore be even less frequent than $\vartheta$; lack of evidence does not necessarily mean the impossibility of its former existence.

(b) A better counterargument is that in some daughter languages the reflexes of traditionally assumed voiced $* \delta$ and $* \delta$ include voiceless $t$ along with the expected $l$ (cf. Honti 1992, 209). In an earlier paper, I proposed that $*_{\Lambda}$ and $*_{\Lambda}^{\prime}$ should be reconstructed instead, even though these cannot be attested in any daughter language, either, in correspondents of the relevant words of the protolanguage; but phonetically and phonologically they fit the system with no inconsistency (ibid.). What is more, according to Bakró-Nagy's studies, syllable structures in the Ostyak dialects that have such phonemes support the plausibility of $*_{\Lambda}$ and $*_{\Lambda}^{\prime}$ and she argued against the likelihood of $*^{*} \delta$ and * $\delta$ (Bakró-Nagy 2001, 21-22). A further advantage of these reconstructed consonants is that they explain the stop reflexes $(t)$ as well as the liquid reflexes $(l)$.

The question might arise if, instead of $*^{\delta}\left(=*_{\Lambda}\right)$ and $*^{\prime} \delta\left(=*_{\Lambda}^{\prime}\right)$, we could not rather posit $* \vartheta$ and $* \vartheta$. The answer is clearly no, since $* \delta\left(=*_{\Lambda}\right)$ and $* \vartheta$ have different reflexes in an overwhelming majority of all Uralic languages. 
Consequently, assuming $* \vartheta$ as a missing link, the phonological obstacle that appeared to be insurmountable so far in the analysis of two Hungarian-Finnish pairs of words has been removed. Thus, we can safely

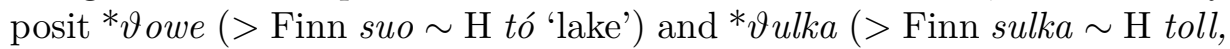
dialectal tolu 'feather') (but we still do not have any reason to assume the existence of $*\}$ in the protolanguage). I furthermore reconfirm my earlier view that $*$ wis $3\left(-m_{3}\right)$ can be posited as a predecessor of e.g., Finnish ydin $(\sim$ ytime $) \sim \mathrm{H}$ velö 'marrow' and also *iéeme ( ${ }^{*}$ Áōme $)$ for Finnish tuomi $\sim$ Ostyak V jom Vogul TJ lēm 'bird cherry'.

2.4. The degree of coherence among members of individual families of words can be seen as indubitable or highly doubtful on the basis of phonological correspondences, the quality of semantic bridges, and a number of other circumstances. Given that our knowledge gradually changes and expands, and becomes increasingly detailed, the assessment of individual etymologies may also change: in cases that have been taken to be indubitable, it may turn out that former scholars were just chasing rainbows, and formerly dismissed etymologies may be reclassified as certain or at least highly probable. Anyone who has ever done etymological research must be aware of this.

2.4.1. Sometimes one might think that such investigations have become pointless for a long time to come since whatever can in principle be known about the origin of the word stock of certain languages or language families is in fact known. However, any etymological dictionary becomes outdated as soon as its authors take it to be ready and finished. In the past decades, both in Uralistics and in studies of other language families new and new etymological dictionaries have been complied that modified our earlier knowledge significantly. A great advantage of these dictionaries is that, by summarising the current body of knowledge, they call researchers' attention to blank spots, and thus the "tread-wheel" revolves on. Etymologists cannot "sit back": they tend to modify the allegedly final and well-established picture by new and new discoveries.

2.4.2. Personally, I have been made to go on "treading the wheel" by the third volume of the newest Finnish etymological dictionary (SSA 3). Its claims allowing for the relatedness of certain Finnish and Hungarian words made me recall one of Tibor Mikola's papers from several decades back (Mikola 1976), originally based on a talk he had given at a conference on the methodology of etymology. The topic of that paper was "Phonology and semantics in etymology". In the introductory remarks of the paper, the 
author presented ideas very close to mine, even if in a different wording (op.cit., 209).

Mikola claimed that the strict observation of historical phonological considerations, in particular, sound correspondences, in etymological research has led to less attention being devoted to semantic factors; that is, whenever a pair of lexemes in two languages exhibited correspondences in one of their phonetic constituents that were not reconcilable with currently held views, even though semantically they matched fairly well or even impeccably, the item exhibiting an irregular reflex was simply excluded from the family of words or the whole correspondence was taken to be erroneous. In his paper, he cited three families of words that he thought would be possible to complement by a word from some related language that semantically matched the others exactly but that contained a segment that appeared to present an insurmountable obstacle. These are the following (op.cit., 211):

1. H toll, etc. $\sim$ Finn sulka, etc., 'feather'

2. H él, Finn elä- Mord éra-, etc., 'live'

3. H száj, Finn suu, etc. Osty V lul, Vj jul, Trj $\Lambda$ u, etc., 'mouth'

UEW (1,535-536) excludes Finnish sulka from this correspondence due to the difference between the initial consonants as Finnish $s$ and Hungarian $t$ cannot correspond to one another, as far as we know today. Mordvin era was included in the family of words with two question marks because of its consonant (UEW 1,73). Osytak V lul went unmentioned in the first volume (UEW 1, 492-493), whereas in the appendix of the second volume it is presented as an indubitable term of another etymology, together with Finnish huuli 'lip' ( Estonian and Lapp) (UEW 2, 903), as Rédei had discovered the obvious but that far unnoticed etymological link on the basis of regular sound correspondences and firm semantic relationship (Rédei 1988b; 1991, 93-95).

One of the most recent etymological dictionaries of the Finno-Ugric language family, SSA (Suomen sanojen alkuperä), does not reject the correspondence between $\mathrm{H}$ toll and Finn sulka. It takes the relationship possible despite the phonological obstacle referred to above (SSA 3, 211). On the other hand, it fails to mention Mordvin era (SSA 1, 103-104), being overly rigorous on that point, in my view. Under huuli, the Ostyak word is mentioned with a question mark (SSA 1, 195) - again showing undue caution in my opinion, given that the two words fit together perfectly both phonologically and semantically, far more than Finnish huuli and Lapp $\mathrm{N}$ sullâ 'approximation to something; suunta, jtakin suunnilleen vastaava 
määrä, jtakin muistuttava ulkonäkö tai muoto', requiring an explanation of semantic change (cf. also E. Itkonen 1975, 175-177).

The incoherence found in the claims of SSA (leaving Mordvin eraunmentioned, the uncertain correspondence with Ostyak lul, and the connection posited between Finnish sulka and $\mathrm{H}$ toll) may perhaps be explained by the fact that the first editor, E. Itkonen, was overly strict in his judgements about sound correspondences (in the case of Mordvin era-) and also overly careful (as in the case of Ostyak lul and Finnish huuli), whereas Kulonen who edited the third volume on his own was more flexible concerning the seemingly problematic phonological correspondence (as in the case of Finnish sulka; cf. SSA 3, 211). I have to add that Kulonen's position may have been affected by the fact that she was able to point at another "Finnish $\sim$ Hungarian etc." correspondence containing the same phonological relationship: Finn suo 'marsh' H tó 'lake' (SSA 3, 213-214), and justified the possibility of relatedness in the same manner as in the case of sulka, that is, claiming that it is possible despite the phonological difficulty.

It is worth pointing out furthermore that Mordvin era- 'live' can hardly be excluded from the family of Finn elä- and H él 'id.', as the phonological irregularity of the latter was convincingly explained by Keresztes:

"Das Wort E M erams 'leben' wird in letzter Zeit vom Verb ung. él fi. elää getrennt. (Literatur dazu s. MSzFE 1: 146.) Neulich machte Mikola (1976, 211) darauf aufmerksam, daß die semantisch vollkommen übereinstimmenden, lautlich aber einen kleinen 'Schönheitsfehler' aufweisenden Wörter zusammengestellt werden können. Was mich betrifft, schließe ich mich der Ansicht Mikolas an. Das PU (FP) * elä- hätte sich im Mordwinischen regelmäßig wie folgt entwickelt: vormd. ${ }^{*} \bar{e} l \ddot{a}->$ urmd. ${ }^{*} \bar{\imath} l_{\partial}->$ altmd. ${ }^{*} i l_{\partial}{ }->\mathrm{E}$ *-ilems, M *iləms. Der Verbalstamm wäre gänzlich mit dem Negationshilfsverb zusammengefallen; vgl. [...] *ila $>$ E ila. Der Wandel $l>r$ trat wahrscheinlich zur Vermeidung der Homonymie ein, wahrscheinlich schon im Voroder Urmordwinischen. (Ein ähnlicher Wandel ist im Hilfsverb des Verbotes fi. älä estn. ära 'nicht!' zu bemerken. Weitere Beispiele für diese Erscheinung s. Rédei 1980, 260). Aufgrund der obigen Tatsachen halte ich für sehr wahrscheinlich, daß das mordwinische Verb mit dem finnischen, ungarischen usw. zusammengehört." 18

(Keresztes 1987, 181-182)

18 "The Erza and Mokša Mordvin verb erams 'live' has recently been disconnected from H él Finn elää (for references, cf. MSzFE 1, 146). More recently, Mikola $(1976,211)$ has pointed out that semantically fully compatible but phonologically 'flawed' pairs of words can be connected with one another. As far as I am concerned, I share Mikola's opinion. PU (FP) *elä- would have regularly developed in Mordvin as follows: Proto-Mordvin ${ }^{*} \bar{e} l \ddot{a}->$ Ancient Mordvin ${ }^{*} \bar{\imath} l_{\partial-}>$ Old Mordvin ${ }^{*} i l_{\partial-}>$ 
With respect to the $r$ in $\mathrm{H}$ három, Rédei cited a few analogous cases: "In Hungarian, we can find a sporadic $* l>r$ change, as in the following words: $\mathrm{H}$ három 'drei' $\sim \operatorname{Vog} \chi \bar{u} r ə m \sim$ Finn kolme; $\mathrm{H}$ világ 'Licht; Welt' $\sim$ virág 'Blume, Blüte' [...]; H csalit R csarit 'Gebüsch, Gesträuch'; halánték $\sim \mathrm{R}$ haránték 'Schläfe'. Cf. also Est ära (dialectal äla, ala) (auxiliary of prohibition) Finn älä" (Rédei 1980, 260; translated from the Hungarian original).

I have to add that a partially similar correspondence "Finnic $s$ - $\sim$ other Uralic (in particular, Lapp) $t$ " exists in the family of Finnish syvä 'deep' (SSA 3, 233), if it goes back to the same item as Finnish tyven 'silent, calm' ( Vog, Osty $t$-) (SSA 3, 350-351); in *tivä, to which syvä goes back, the change ${ }^{*} t i>s i$ regularly occurred, followed by ${ }^{*} i>\ddot{u}$ due to the labializing effect of $v$; on the other hand, in the word tyven, labialisation must have preceded the sound change ${ }^{*} t i>s i$ ( $\mathrm{T}$. Itkonen 1982, 161-162). Thus, the Finnic family of words at hand clearly must have a historical phonological background different from that of sulka 'feather' and suo 'marsh' mentioned above, that is, it must be historically distinct from the phonological relationship of Finn suo $\sim \mathrm{H}$ tó, Finn sulka $\sim \mathrm{H}$ toll. Unless we clarify the historical source of this phonological relationship, resolving this irritating puzzle, we cannot but play with the idea that the words sulka and suo may be suspected to be of ancient origin without being able to justify this suspicion.

There is yet another Finnic word with initial $s$ - whose counterpart in related languages is t-: Finn sika 'Schwein' Mord E tuvo, M tuva 'id.', but this correspondence has a different explanation (cf. E. Itkonen 1946, 305-306; UEW 2, 796; SSA 3, 178).

As part of his reasoning, Mikola $(1976,210)$ quotes Valentin Kiparsky: "ich bleibe dabei, daß bei scheinbar unüberbrückbaren semantischen Klüften zunächst einmal versucht werden soll, Brücken zu schlagen"19 (Kiparsky 1966, 75), and adds, “[...] I think Kiparsky's semantic claim can be complemented by a phonological one: Where we see an apparently unbridgeable phonological abyss, but where everything else supports an ety-

$\mathrm{E} *$ *ilems, M *ilams. However, the verb stem would have fully coincided with the negative auxiliary, cf. [...]*ila $>$ E ila. The sound change $l>r$ probably occurred in order to avoid homonymy, probably already in Proto- or Ancient Mordvin. (A similar change can be seen in the auxiliary of prohibition: Finn älä $\sim$ Est ära 'don't!'.) For further examples that illustrate this phenomenon see Rédei (1980, 260). On the basis of these facts I think it is probable that the Mordvin verb for 'live' belongs together with the corresponding Finnish, Hungarian, etc. verbs."

19 "My opinion is that, in the case of seemingly unbridgeable gaps, one has to try and build bridges." 
mological relationship, we have to try, at least, to build a bridge" (Mikola 1976, 211; translated from the Hungarian original). Now, in what follows, I will try to bridge the gap.

2.4.3. In what follows, I will try to justify the relatedness of the above Hungarian and Finnish words by attempting to prove the regularity of the phonological correspondence that has been known as irregular so far.

The correspondence of Finn suo $\sim \mathrm{H}$ tó, etc. was accepted up to the end of the 19th century. Later on, it was rejected due to the phonological difficulty that was recognised, except for a single scholar who claimed that the Finnish word represented an irregular case (Janhunen 1981, 257; cf. also SSA 3, 213-214).

In the instance of Finn sulka $\sim \mathrm{H}$ toll, etc., rejections were given in the second half of the 20th century; again, SSA knows of a single view, that of Sammallahti $(1988,540)$ that takes the correspondence to be possible, albeit with a question mark (SSA 3, 211).

It is obvious that the protolanguage forerunner of the initial consonant of these Finnish-Hungarian pairs of words cannot be an element from which, as far as we know today, we could explain Finn(ic) $s(<\mathrm{U} / \mathrm{FU} * s$, $\left.{ }^{*} s\right)$, on the one hand, and Hungarian etc. $t$ - $\left(<\mathrm{U} / \mathrm{FU}{ }^{*} t-\right)$, on the other; in interpreting this correspondence, we clearly cannot entertain the hypothesis that Finnic $s$ can occur in the position of ${ }^{*} t$, given that it only occurs in the sequence ${ }^{*} t i$, cf. e.g., Finn sinä $\mathrm{H}$ te 'you-sg'. That is, in this case, we have to find a bypass solution, that is, we have to postulate an initial consonant that has not survived in the daughter language representations of these words but is able to justify the relatedness of these pairs of words phonologically. This consonant cannot be anything else but the voiceless interdental spirant, $\vartheta$. Both $\vartheta>s$ and $\vartheta>t$ are changes attested in the world's languages, they are phonologically plausible and natural. (Incidentally, $\vartheta$ and $\delta$ are not necessarily produced with an interdental constriction; they can be pronounced between the teeth and the tip of the tongue, too; see e.g., Zinder 1979, 158-159; this makes the changes $\vartheta>s$ and $\vartheta>t$ even more straightforward.)

We should also mention that Janhunen raised the possibility (although very cautiously) that Finnish sulka 'feather' and tuuli 'wind' might be related (1981, 241; I find this idea absurd). He does not explain the uncommon sound correspondence "Finnic $s \sim$ other Uralic $t$ " but merely refers to it in discussing the word family meaning 'lake' among other cases of "irregular sound correspondences", that is, he says that Finnish sulka is just another case of irregular sound correspondence (op.cit., 257). 
Against my explanation of the correspondence of "Finnic $s \sim$ other Uralic $t$ ", one could raise three objections, as far as I can see:

(a) in order to "salvage" these etymologies, I have reconstructed an element that cannot be attested in present-day reflexes of the given words, hence it is the result of mere speculation, and such a protolanguage consonant has not even been postulated so far;

(b) if my assumption is correct, this is a very little loaded phoneme; and

(c) my explanation can only be correct if $* \vartheta$ was preserved until the late Proto-Finnish period and only turned into $s$ afterwards, whereas in the other languages of the family, it turned into $t$ in the secondary or tertiary protolanguages.

(a) Reconstructed protolanguage forms nearly always contain consonants that exist in some daughter-language derivatives of the reconstructed item, cf. e.g., PFU *käte > Finn käsi, käte- H kéz 'hand', PFU * šine-re > Finn hiiri Voty šir Zyr šįr Osty V lögkar, Vog TJ tägkar, H egér 'mouse'. In the reconstructed PFU consonant system, I know of only two items that fail to occur in present-day reflexes of hypothetical protolanguage lexemes containing them; namely, ${ }^{*} \delta$ and $* \delta$. Of course, it is easier to genuinely verify mutual correspondences and tendencies of sound change if our reconstructed forms are made up of elements of attested lexemes; the former existence of elements whose being there is only speculatively inferred, on the other hand, can only be verified on the basis of their phonological plausibility and the probability of the hypothetical processes of sound change they are said to undergo. And if we reconstruct an element of the protolanguage that was not assumed so far to have existed, provided that we reconstruct it with good reason, our knowledge becomes more nuanced at best.

(b) It is a commonplace that only a fraction of the lexemes of a reconstructed protolanguage are actually known, hence we can only advance tentative ideas about how loaded a given phoneme may have been (within the protolanguage word stock). But this is perhaps not too important: the frequency of occurrence of individual phonemes ranges over a wide scale in present-day languages and dialects, too. Since many witnesses of the onetime system disappeared without trace from the members of the language family during the 6000 years or so of its history, we have to rely on the testimony of few but well-established data. I think that the reconstructed protolanguage phoneme that I propose accounts for the relationship between the members of the two pairs of words that the present section is 
primarily concerned with. Similarly, my explanation of the internal con-

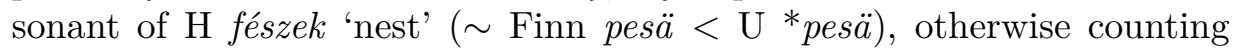
as irregular, can be taken to be well-established for the same reason: it is based on an assumed phonological change that is regular but only occurs in a single piece of data (Honti 1983, 113-117; an analogous Sayan-Samoyedic sound change is reported by Helimskij 1987).

(c) The explanation of the relationship "Finnic $s \sim$ other Uralic $t$ " based on $* \vartheta$ can be made chronologically plausible by assuming that the change ${ }^{*} \vartheta>t$ failed to reach the westernmost part of the Uralic language area until the separation of Late Proto-Finnish. Furthermore, the same change $* \vartheta>t$ must have also occurred in a fairly early part of the life of ProtoUgric, otherwise $\mathrm{PU} / \mathrm{PFU}{ }^{*} \vartheta$ would have coincided with Ugric $\left(* s \times{ }^{*} \check{s}>\right)$ $* \vartheta$, in which case they would have produced identical reflexes.

\section{On the relationship between PU/PFU/PUg ${ }^{*} 3 m_{3}$ and ${ }^{*} \mathrm{C}(3) \mathrm{m}_{3}$ and their reflexes in Hungarian ${ }^{20}$}

Of $\mathrm{U} / \mathrm{FU} / \mathrm{Ug}$ intervocalic *-m, Róna-Tas writes: "In intervocalic position it has a) been preserved as $/ \mathrm{m} /$ in 9 cases (9 PFUgr), or b) became through /w/ > /v/ in 10 cases" (Róna-Tas \& Berta 2011b, 1020).

$\mathrm{Of} \mathrm{U} / \mathrm{FU} / \mathrm{Ug}{ }^{*}-m$ occurring in consonant clusters, he writes: "In clusters with consonants before $/ \mathrm{m} /$ the $/ \mathrm{m} / \mathrm{a}$ ) is preserved in 4 cases (all PFUgr), or b) became /v/ in 1 case (PFUgr) [...]. In 1 case we find /mw/ in $\mathrm{H}$ " (op.cit., 1022). Although the monograph does not discuss ${ }^{*} C_{3} m 3$ consonant clusters, I have to reflect on these, too, since their reflexes are similar to those of ${ }^{*} \mathrm{Cm} 3$.

I will examine the following consonants and consonant clusters:

1. $\mathrm{U} / \mathrm{FU} / \mathrm{Ug} * m$ (of these, I only discuss those involving a Hungarian member)

2. $\mathrm{U} / \mathrm{FU} / \mathrm{Ug} * l m$

3. $\mathrm{U} / \mathrm{FU} / \mathrm{Ug} * l 3 m$

4. $\mathrm{U} / \mathrm{FU} / \mathrm{Ug} * \mathrm{~lm}$

5. $\mathrm{U} / \mathrm{FU} / \mathrm{Ug} *_{\Lambda m}$

6. $\mathrm{U} / \mathrm{FU} / \mathrm{Ug} *_{\Lambda 3 m}$

${ }^{20}$ In clusters, $C=l, l, \Lambda, \Lambda, r, j$. The primary topic of the present section includes sequences in which $C$ is a liquid; sequences involving $j$ are discussed merely for the parallel they exhibit. The symbol 3 stands for 'any vowel'. 
7. U/FU/Ug *ím

8. U/FU/Ug *ím or *ísm

9. $\mathrm{U} / \mathrm{FU} / \mathrm{Ug} * r m$

10. $\mathrm{U} / \mathrm{FU} / \mathrm{Ug} *$ r $3 m$

11. $\mathrm{U} / \mathrm{FU} / \mathrm{Ug} * j m$

Nearly a century ago, Wichmann studied the reflexes of $* l m$ and $* l m$ in Finno-Ugric languages on a much smaller material; his results are reliable but obviously not comprehensive:

"Die Vertretung der fraglichen Konsonantenverbindungen ist in den angeführten Belegen also hauptsächlich die folgende: ${ }^{21}$

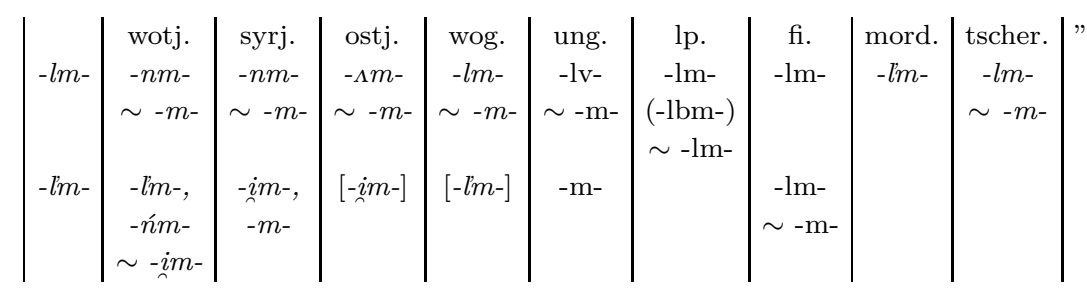

(Wichmann 1915, 43)

He interpreted the reflexes of these clusters as results of gradation, an idea that has become obsolete since (op.cit., 44). Collinder (1960, 143-144) must have summarised the story of these clusters on the same basis.

\subsection{Etymological database (U, FU, Ug, FP, FV)}

$$
\text { 1. }{ }^{*} m
$$

Word internal *-m- has two reflexes in Hungarian:

$$
\nearrow \text { a. }\left({ }^{*} w>\right) v
$$

(1) $*_{-}-m-$

b. $m$

21 "The consonant clusters at issue mainly show the following reflexes in the examples cited." The translations of the table headers: "Votyak, Zyrian, Ostyak, Vogul, Hungarian, Lapp, Finnish, Mordvin, Cheremiss". 
The following Hungarian words belong here (for the sake of completeness, I add etymological word families without a Hungarian member, too, as well as recent claims with respect to the etymologies and the reflexes):

$$
\text { (1a) }(* w>) v
$$

1. Ug *joms (“jams) 'gut' > Osty jĕm, Vog joməs, H jó $\sim$ jav- (UEW $2,850)$.

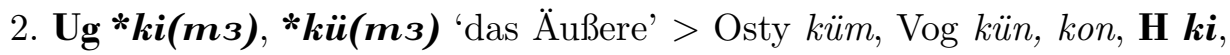
OH kivé (UEW 2, 857).

3. U *oma 'alt, vorig, vorherig' > Lp oames -bmas-, Mord umok, Cher üma, H o, avas, Mot omo, Kar umuń, Taigi umo, the $\mathrm{H}$ word also under

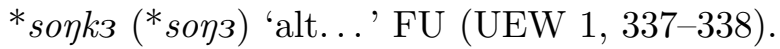

4. U*kums 'dünner Schnee' > Voty kim, H hó $\sim \boldsymbol{h a v}$-, Yur $\chi a w^{?}$, Kam kamo (UEW 1, 204)

FU *kumi > FP *kumi, Ug *kŭmu (Sammallahti 1988, 544).

5. FU *leme (*lēme) 'Saft, Suppe' > Finn liemi, Est leem, Lp liebma, Mord lem, Cher lem, Voty lim, Zyr lem, Vog läm, lamm, H lé $\sim$ lev- (UEW 1, 245).

$\mathrm{FU} *$ leemi $>\mathrm{FP} *$ leemi $\sim \mathrm{Ug} *$ läm $\breve{\imath}$ (Sammallahti 1988, 545).

6. U *nime 'Name' > Finn nimi, Est nimi, Lp nâmmâ, Mord lem, Cher lam, Voty ńim, Zyr ním, Osty nem, Vog näm, nam, H név $\sim$ nev-, Yur ńum?, Yen ni $i^{\text {? }}$, Tvg niim, Slk nim, Kam nim, Koib nim, Mot numme-de (UEW 1, 305).

$\mathrm{U}^{*}$ nimi $>$ Sam ${ }^{*}$ nim $\sim \mathrm{FP} *^{*}$ nimi (Janhunen 1981, 234).

$\mathrm{U} *^{*} n i m i>\mathrm{Sam}{ }^{*} n u m \sim \mathrm{FU}{ }^{*} n i m i>\mathrm{FP}{ }^{*} n i m i \sim \mathrm{Ug}{ }^{*} n \iota m \iota ~(S a m-$ mallahti 1988, 545).

7. U *ńoma(-l3) 'Hase' > Lp njoammel, Md numolo, Zyr níma•l, H nyúl, Yur ńāwa, Yen ńába, Tvg. ńomu, Skp njoma, njoo (UEW 1, 322).

$\mathrm{U} *$ ńoxmå $>$ Sam *ńåàmå $\sim \mathrm{FP} *$ ńoma- (Janhunen 1981, 242).

$\mathrm{U}^{*}$ ńomå $>\mathrm{Sam}{ }^{*}$ námå $\sim \mathrm{FU}{ }^{*}$ ńomålå $>\mathrm{FP}{ }^{*}$ nomala $\sim \mathrm{Ug} *$ ńåmala (Sammallahti 1988, 539).

8. Ug *pims 'Gras' > Osty pam, Vog pum, H fü füv- (UEW 2, 879).

9. FU * wømз 'Zauberwort' > ?Zyr vomiź, ?H im-ád, uncertain because of the Zyrian vowel (UEW 1, 589; but cf. Róna-Tas \& Berta 2011a, 455-457).

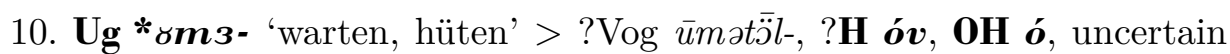
because the word is only known in one Vogul dialect (UEW 2, 901; but 
cf. Róna-Tas \& Berta 2011b, 1233); alternative etymological explanation: FU *šoma or *š̄̄ma 'защита; защищать' > Finn huoma 'protection, providence', huomaa- 'notice, perceive' $\sim$ H óv 'shelter (vb)' (Rešetnikov 2011, 110-111). - The Finnish family of words was said to be a Germanic loan by Koivulehto $(1976,248)$, a claim accepted as impeccable by the authors of a dictionary of early Germanic elements in Finnic languages (Kylstra et al. 1991, 123-125), while the three-volume Finnish etymological dictionary mentions it with caution: "on ehdotettu germ alkuperä" ["Germanic origin has been suggested"] (SSA 1, 186). Häkkinen (2007, 220-221) was cautious due to semantic reasons. As alternatives, both explanations are feasible (?Vog $\bar{u} m ə t \bar{\partial} l-$ 'warten, erwarten' $\sim$ ?H $\boldsymbol{o} \boldsymbol{v}, \mathbf{O H} \boldsymbol{o}$ and Finn huoma 'protection, providence', huomaa- 'notice, perceive' $\sim$ H ó $\boldsymbol{v}$ ); for our present purposes it is immaterial which one is better, given that we can count with a change $\mathrm{FU} / \mathrm{Ug}{ }^{*} m>\mathrm{H}\left({ }^{*} w>\right)>v \gtrsim \overline{3}$ in both cases.

\section{(1b) $m$}

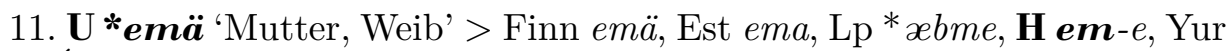

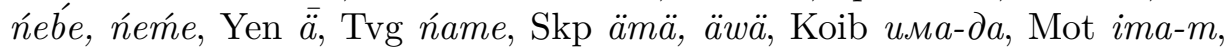
Taigi emme, ima-m (UEW 1,74), Tvg nemi 'ema; Mutter' (EES 61); both SSA $(1,104)$ and EES $(60-61)$ present identical data.

$\mathrm{U} * \ddot{a} m \ddot{a} /{ }^{*}$ emä $>\mathrm{Sam}{ }^{*}$ emä $\sim \mathrm{FP}{ }^{*}$ em $\ddot{a}$ (Janhunen 1981, 257).

$\mathrm{U}{ }^{*} e m \ddot{a}>\mathrm{Sam}{ }^{*}$ em $\ddot{a} \sim \mathrm{FU}{ }^{*}$ em $\ddot{a}>\mathrm{FP} *$ emä $\sim \mathrm{Ug} *$ em $\ddot{a}$ (Sammallahti 1988, 536).

12. U *ime- 'saugen' > Finn ime-, Est ime-, Osty em-, H em-ik, Yur ńimńe-, пат́ā-, Tvg ńimiri-, Skp ńem-, Kam ńimēr-, ете̄r-, ?Mоt нюмніямл, ?Taigi nímu (UEW 1, 82); the Finnic etymological dictionaries present a slightly different picture: Lp njâmmât, Zyr nimavni, the Motor item is lacking (SKES 1, 107), Lp njâmmât, Zyr nimavni and Mot нюмніямл do not осcur; SSA $(1,226)$ notes that UEW excluded the Lapp and Zyrian words because of their ń-, EES (92) mentions these two with a question mark.

$\mathrm{U} *^{*} i m i-\left(? /{ }^{*}\right.$ ńimi- $)>\mathrm{Sam}{ }^{*}$ ńim- FP *imi- (Janhunen 1981, 256), the form ?* nimi- is included because of Lp and Zyr ń-.

$\mathrm{U} * i m i->$ Sam ${ }^{*}{ }^{*} i m-\sim \mathrm{FU} *^{*} i m i->\mathrm{FP} *^{*} i m i-\sim \mathrm{Ug} * \imath m \breve{\text { - }}$ (Sammallahti 1988, 536).

To me it appears that Janhunen's double reconstruction is wellfounded; it is not too probable that languages that are distantly related should have produced words beginning with the same consonant that otherwise appear to be completely in correspondence with the relevant words 
in the other related languages. But if this had nevertheless happened, the Lapp, Zyrian and Motor reflexes of $\mathrm{U} *^{*}$ ime- 'saugen' must have been expanded by a secondary initial consonant.

13. U*jom3- 'gehen, sich auf den Weg machen' > Vog jām-, ?H in-dul, Yur $j \bar{a} m$-; the Hungarian word only belongs here if the change ${ }^{*} m>n$ happened in it before $d$ (UEW 1, 100). I have the impression that the condition in UEW for taking the $\mathrm{H}$ word to belong to this family was indeed met, hence $I$ think the question mark before the Hungarian form is superfluous.

14. U *kama 'Schale' > Finn kamara, Est kamar, Cher kom, Voty kem, kumel, Zyr komell, ?Vog -kamtul, H hám-lik, Yur śāw, śem, Tvg kamu, Skp qåm, Kam kåm (UEW 1, 121-122); SKES (1, 293-294) relates the Finnic data to the non-Finnic ones with a question mark; SSA (1, 293-294) and EES (124) do the same.

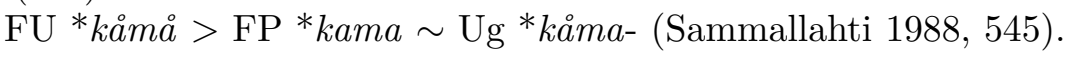

15. ?U, FU *kä̈mä 'hart, fest' > ?Finn kämä, Mord keme, H kem-ény, ?Skp qōm, ?Kam komdə- (UEW 1, 137); Finn kämä, and similar words are listed in SSA $(1,472)$, but it is claimed that the Finnish word is unrelated to Mord keme, kemä and $\mathrm{H}$ kemény.

$\mathrm{FU}{ }^{*} k \ddot{a} m \ddot{a}>\mathrm{FP}{ }^{*} k \ddot{a} m \ddot{a} \sim \mathrm{Ug}{ }^{*} k \ddot{a} m \ddot{a}$ - (Sammallahti 1988, 545).

16. U *kuma 'gebeugte, umgestürzte Lage' > Finn kumo, Est kummo, Lp gemo, Mord koma-, Cher kâmàk, Voty kimes, Zyr kim: śin-kim, kimęs,

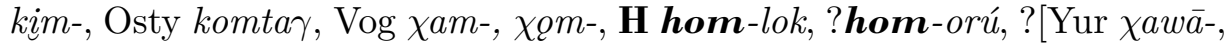
?Yen ka?aða, ?Tvg kamágu], Skp qamt, ?Kam kama? (UEW 1, 201202), "Zu dem von mehreren Forschern irrtümlich hierher gestellten finn. kulma 'Winkel': silmä- od. otsa-kulma 'Schlafbein' und seine Familie [...] s. *kulma 'Stelle über od. neben den Augen [...]' FU. [New paragraph] Einige Forscher [...] rechnen in den permischen Wörtern für 'Stirn' mit der Konsonantenverbindung $l m$ bzw. $l m$ und vergleichen die Wörter ebenfalls mit finn. kulma und seinen Verwandten. Da die permischen Wörter die regelmäßigen Fortsetzungen der angenommenen Lautverbindungen nicht enthalten, ist diese Ansicht unwahrscheinlich"22 (UEW 1, 202). SSA (1, 435-436) includes H homlok 'forehead' with a question mark; EES (191)

22 "The Finnish word family kulma 'Winkel': silmä- or otsa-kulma 'Schlafbein' is erroneously included here; cf. under *kulma 'Stelle über od. neben den Augen [... .]' FU. [New paragraph] Some researchers [...] count with the clusters $l m$ and $\mathrm{lm}$ in Permic words for 'Stirn, forehead', also relating it to Finnish kulma and its relatives. Since the Permic words do not include regular reflexes of the assumed clusters, this view is unlikely to be true." 
adds Mot kamaga 'puunott, kaldale, uhutud puu; Klotz, Treibholz', but does not mention the Kamass form. - For an alternative etymological explanation of $\mathrm{H}$ homorú 'concave', cf. entry 18 (FU *køm3 'Höhlung, hohl') below.

$\mathrm{U}^{*} k u m a ̊ ~>$ Sam *kâmวิ- $\sim \mathrm{FP}{ }^{*} k u m a-($ Janhunen 1981, 226).

$\mathrm{U} * k u m a ̊>\mathrm{Sam} * k \theta m \theta^{-} \sim \mathrm{FU} * k u m a ̊>\mathrm{FP} * k u m a-\sim \mathrm{Ug} * k u ̈ m a-$ (Sammallahti 1988, 537).

17. FU *kum3 'Wolke' > ?Finn kumuri, Mord kovol, Zyr kimer, Vog

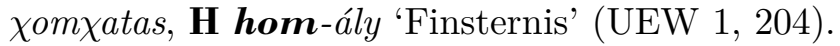

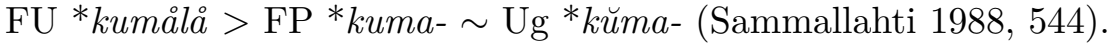

18. FU *køm3 'Höhlung, hohl' > ?Finn komi, komo, komero, ?Lp goabmâ -m-, ?Cher kom, ?Osty kŏm, ?H hom-orú (UEW 1, 227); UEW takes the whole family to be uncertain, probably with good reason.-For an alternative etymological explanation of $\mathrm{H}$ homorú 'concave', cf. entry 16 (U *kuma 'gebeugte, umgestürzte Lage') above. SSA $(1,394)$ takes the Finnic words to be descriptive ones and takes Lp goabmâ to be a Finnish loanword, thus its view practically coincides with that of UEW.

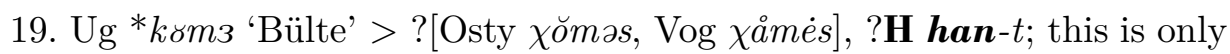
correct if the $\mathrm{H} n$ goes back to earlier ${ }^{*} m$ and is due to the assimilatory effect of $t$ (UEW 2, 860). In my view, it is highly probable that the three words go back to a common predecessor as they fit together well in all respects and the explanation of ${ }^{*} m>\mathrm{H} n$ appears to be reassuring; hence I take this correspondence to be certain.

20. FP ?FU *lume 'Schnee' > Finn lumi, Est lumi, ?Lp lobma, Mord lov, lò, Cher lâm, Voty lịmi, Zyr lịm, ?H lom 'junk' (UEW 1, 253-254). The Hungarian word is rather unlikely to belong here due to semantic reasons, though it is not outright impossible.

$\mathrm{U} *$ lumi $>$ Sam *jom- $\sim \mathrm{FP} *$ lumi (Janhunen 1981, 231).

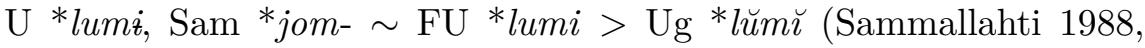
538).

In Zyrian, this word also has a secondary stem form extended by $j$ (cf. Csúcs 2005, 133), probably due to an analogical change.

21. FU *'śoms 'Hunger, Durst' > Voty śumem, Zyr śimal-, H szom-jú (UEW 1, 485).

$\mathrm{FU} *^{*}$ śomå $/ i->\mathrm{FP} *$ śoma- $\sim \mathrm{Ug} *$ somŕ- (Sammallahti 1988, 549); he further included the following words: Mord śumordo-, Voty śuma/z-, $\mathrm{H}$ szomorú 'sad', szomjas 'thirsty', that is, he took entries 21 and 22 to be a single family. However, according to $\mathrm{UEW}(1,485)$, Mord śumordo- and $\mathrm{H}$ 
szomorú are questionable derivatives of $\mathrm{FU}{ }^{*}$ śom3-r3 'Kummer, Trauer; ?traurig sein' (here, entry 22).

22. FU *som3-r3 'Kummer, Trauer; ?traurig sein' > ?Mord śumoŕdé?H szomorú (UEW 1, 485).

$\mathrm{FU} *^{*}$ śomå $/ i$ - > FP *śoma- $\sim \mathrm{Ug}{ }^{*}$ somŭ- (Sammallahti 1988, 549); as pointed out above, he further included the following words: Mord śumordo-, Voty śuma/z-, H szomorú, szomjas, that is, he took entries 21 and 22 to be a single family. I take Sammallahti's solution to be semantically unfounded, hence I think two separate entries are necessary here.

23. FU *tem 3 'voll; stopfen, füllen' > Cher temə, teme, H töm, tem-et (UEW 1, 520; cf. also Bárczi 1958, 113-114).

$$
\text { 2. }{ }^{*} l m
$$

The cluster ${ }^{*} l m$ has four reflexes in Hungarian:

$$
\begin{aligned}
(2)^{*} l m & \nearrow \quad \text { a. } m \\
\searrow & \text { b. }\left({ }^{*} l w>\right) l v \sim l \overline{3} \\
& \text { c. }\left(\mathrm{Ug}{ }^{*} l m \gtrsim{ }^{*} r m>\right) r 3 m \\
& \text { d. } l 3 m
\end{aligned}
$$

\section{(2a) $m$}

24. FU *ćolme 'Knoten, Bündel; binden' > Finn solmu, Est sõlm, Lp čuol'bmâ, Mord śulmo, śulma, H csom-ó (UEW 1, 38); Hungarian -ó $\left(<{ }^{*}{ }_{-} m_{3} /{ }^{*}-p_{3} /{ }^{*}{ }_{-} \eta 3\right)$ is a derivational suffix; SSA $(3,196-197)$ and EES (494) list the same reflexes.

FU *śolmi > FP *śolmi $\sim \mathrm{Ug} *$ somu (Sammallahti 1988, 549).

25. U *śilmä 'Auge' > Finn silmä, Est silm, Lp čâl'bme, Mord śelme, Cher sənzä, Voty śin (śinm-), śin (śińm-), Zyr śin (śinm-), Osty sem, Vog sam, H szem, Yjur sew, häem, Yen sei, Tvg śäimə, Skp saj, Kam sima, Koib

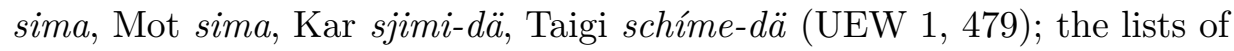
SSA $(3,181)$ and EES $(473)$ are identical with that of UEW; in Permic *lm > Zyrian jm, jim, Votyak ńm, ń occurred (cf. Bárczi 1958, 113-114, $115)$.

$\mathrm{U} *$ śilmä $>$ Sam *sâmä $\sim \mathrm{FP} *$ śilmä (Janhunen 191, 225).

$\mathrm{U} *$ śilm ä $>$ Sam *sejmä $\sim \mathrm{FP} *$ śilmä $\sim \mathrm{Ug} *$ sı̆mä (Sammallahti 1988, 540). Cf. also Csúcs (2005, 137, 150). 
(2b) $\left({ }^{*} l w>\right) l v \sim l \overline{3}$

26. FU *ńälmä 'Zunge' > Lp njal'bme, Cher jalmə, Osty ńäləm, Vog ńélam, H nyelv (UEW 1, 313-314); also H nyelő: nièlo (TESz 2, 1041). According to the Finnic etymological dictionaries, the Finnic words Finn nälvä 'lima; Schleim', nälvïa 'syödä haluttomasti; eat reluctantly', Inkeri nälviä 'nälviä, ivata; peck, tease', Lyd nä̈lme 'home vedenpinnalla; Schimmel im Wasser', Vepse nällmotada 'mutustella; munch', Est dialectal nälv (gen. nälva) 'lima; Schleim' may be related to the word family of $\mathrm{H}$ nyelv; semantically close items are niellä 'swallow', nuolla 'lick' and nolki 'lima, kuola; Schleim, Geifer' (SSA 2, 251); Est nälpama 'limpsama; lick', perhaps derived from the same Finnic or Finno-Ugric stem as dialectal nälv 'ila; phlegm' whose correspondents are Finnish dialectal nälvä 'lima; phlegm', Inkeri nälviä 'pilgata, mõnitada; mock, make ridiculous', Lyd ńälme 'hallitus veepinnal; viscous surface of water', Vepse nä̈mlotada, nä̈lmotada 'närida, mäluda; bite, chew'; these can be compared to the UEW list (EES 327). The etymological connections mentioned by the Finnic etymological dictionaries are just possible; if they are correct, the PFU forerunner of $\mathrm{H}$ $n y e l v$ was a derived form involving the suffix $*_{-} m 3$.

FU *nelmä 'mouth' > FP *nälmä Ug *nelmä (Sammallahti 1988, $546)$.

(2c) $\left(\mathrm{FU} * l m>\mathrm{Ug} * l m \gtrsim{ }^{*} r m>\mathrm{H}\right) r 3 m$

27. FU *kolme (*kulme) 'drei' > Finn kolme, Est kolm, Lp gol'bmâ, Mord kolmo, Cher kâm, Voty kwiń (kwińm-), Zyr kujim, kvim, Osty xolam, Vog $\chi \bar{u} r ə m$, H három (UEW 1, 174); SSA (1, 391-392) and EES (173) give the same list. $\mathrm{FU}{ }^{*}$ kolme $\left({ }^{*}\right.$ kulme $)>\mathrm{Ug}{ }^{*} k \diamond l 3 m 3 \gtrsim \mathrm{Ug} * k \diamond r 3 m 3$ (L. H.). $543)$.

$\mathrm{FU} *$ kolmi $>\mathrm{FP} * k o l m i \sim \mathrm{Ug} * k u / \ddot{a} / \mathrm{a} l m / r m \breve{\imath}$ (Sammallahti 1988,

$$
(2 \mathrm{~d}) * l_{3} m
$$

28. Ug *wølm3 'Blei' > ?Vog wōlam, H ólom 'Blei' (UEW 2, 899); given with a question mark because only these two languages have it. In my view, this correspondence is certain. FU *woln $3>$ Cher wulnəิ, Osty olnə, $\mathbf{H}$ ón 'Zinn'; also, H ólom is mentioned with a question mark (UEW 1, 581); but I think the last correspondence is in error: there is no reason why ${ }^{*} n$ is lost and $m$ appears. 


$$
(2 \mathrm{e}) * l m
$$

No Hungarian reflex.

29. FU *ilma 'Himmel, Wetter; Gott' > Finn ilma, Est ilm, Lp âl'bme, Voty in (inm-), iń (ińm-), Zyr jen (jenm-), Osty ilam, Vog jēlam, èlam (UEW 1, 81); SSA $(1,224)$ and EES (91) present the same data.

$\mathrm{FU} * i l m a ̊>\mathrm{FP} * i l m a \sim \mathrm{Ug} *$ jilma (Sammallahti 1988, 541).

Cf. also Csúcs (2005: 137, 150).

30. FP *julma 'stark, kräftig' > Finn ?julma, ?Lp jul'bme, ?[Voty jun (junm-), Zyr jon (jonmed-)] (UEW 2, 638); Finn julma, ??[Voty jun, Zyr jon]; Est julm and Lp jul'bme are Finnish loanwords (SSA 1, 246), Est julm is a Finnish loanword (EES 100).

Cf. also Csúcs (2005, 137).

31. U *kalma 'Leiche; Grab' > Finn kalma, Est kalm, ?Lp guolmâs -l'bm-,

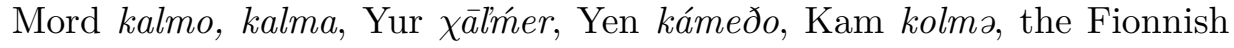
word cannot be related to the Finnish verb kuole- because of the vowel (UEW 1, 119-120); SSA (1, 288) and EES (123) link the Samoyedic words here with a question mark only, and some people take it to be likely that the Finnic words are of Germanic origin (SSA, EES), or perhaps (says EES) they are only derivatives of $\mathrm{U}^{*}$ kola- 'sterben' (UEW 1, 173).

32. FP *kelmä 'Haut, Häutchen' > ?[Finn kelme, Est kelme], ?Zyr keń, kiń, "Der Stamm im Syrj. ist keń-, kiń-. Die Zusammenstellung ist nur dann akzeptabel, wenn der syrj. Stamm früher ${ }^{*} k e n ́ m-$, ${ }^{*} k i n m-\left(<{ }^{*} n m\right.$ $<* l m)$ war. Der Schwund von $m$ und die Mouillierung von $n$ lassen sich möglicherweise durch den Einfluß von kiń, keń: bi-keń 'Funke' erklären, das eine ähnliche Lautform hat"23 (UEW 2, 657). Tha data in SSA (1, 341) and EES (143) are the same; SSA takes the Zyrian form to go back (possibly) to ?*keńmi.

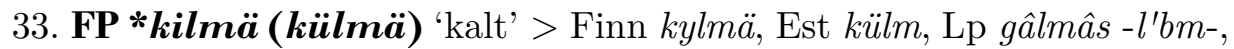
Mord kel'me, Cher kalma, Voty kân (kânm-), kinnmi-, Zyr kỉn, kinnmi- (UEW 2, 663); $\operatorname{SSA}(1,431)$ and EES (213) have the same data.

FP *külmä (Sammallahti 1988, 552). Cf. also Csúcs (2005, 137, 150).

34. FP *solma 'Tal, Vertiefung' > ?[Finn salmi, Est salm, Lp čoal'bme], ?[Voty śum, Zyr śon] (UEW 2, 775); SSA (3, 148) only mentions the Finnic and Lapp words, EES (458) takes it to be Finnic only.

23 "The Zyrian stem is keń-, kiń-. The connection is only acceptable if the Zyrian stem used to be ${ }^{*} k e n m-,{ }^{*} k i n m-\left({ }^{*} n m<{ }^{*} l m\right)$. The loss of $m$ and the palatalisation of $n$ is perhaps due to the effect of the similar-sounding kiń, keń: bi-ken 'Funke." 
3. $* 13 m$

The sequence $* l 3 m$ has two reflexes in Hungarian:

$$
\begin{array}{cl} 
& \nearrow \text { a. } l 3 m \\
& \searrow \text { b. }(* l 3 m w>) l v \sim l 3 \sim l
\end{array}
$$

(3a) $l 3 m$

35. Ug *ala-ma (*al3-ms) 'Einlage im Schuh (aus Heu)'> Osty i isəm, H alom 'litter' (UEW 2, 831), perhaps derived from U ala 'Raum unter etwas' (UEW 1, 6), see also U *ilå > Sam *ilâ $\sim$ FP *ala (Janhunen 1981, 227, 273), U*ilå > Sam *ile FU *ila > FP * ëla Ug ila 33 (Sammallahti 1988, 536). As correctly noted by Csúcs \& Molnár (2009, 3233 ), the alternative source form should clearly have a velar vowel, thus: *alø-mъ, but this is of course irrelevant for our present purposes.

$$
\text { (3b) } \mathrm{H}(* l 3 w>) l v \sim l 3 \sim l
$$

36. Ug ${ }^{*} \ddot{\boldsymbol{a}} \mathbf{l} \mathbf{3}\left({ }^{*} \ddot{\boldsymbol{a}} \boldsymbol{l}(\mathbf{3})-\mathbf{m} \mathbf{3}\right)$ 'andere Seite' > Osty $\ddot{a} \Lambda \partial m, \mathrm{Vog} \ddot{a} l \partial m, \mathbf{H} \boldsymbol{e l v}$ $\boldsymbol{e l} \ddot{\boldsymbol{u}}, \boldsymbol{e} \boldsymbol{l} ;$ the $\mathrm{H}$ variant el lost the reflex of ${ }^{*} m$.

No Hungarian reflex:

37. FW * ćil3-m3 'Eckzahn (von Raubtieren)' > Lp čâlam, Mord ćilem-, śelän- (UEW 2, 613-614).

$$
\text { 4. } * \text { lm }
$$

No Hungarian reflex.

38. FU *kul'ma 'Stelle über od. neben den Augen' > Finn kulma, Est kulm, ?Lp gul'bme, Osty kul'am (UEW 1, 201); SSA (1, 431) and EES (190) list the data without the Lapp word; according to E. Itkonen (1954, 167, 300) Zyr kim: śin-kim kimes, kimis also corresponds to Finn kulma; Lytkin $(1957,77)$ links Zyr kun: kun-va 'щёлюк' with the Finnish word but does not list it in his Zyrian etymological dictionary; KESK (151) also includes Zyr kimes 'лоб, чело', Voty kimes 'id.' < Proto-Permic *kumes 'id.', where the Zyr stem is kim: śin-kim 'бворь' $\sim$ H hom-lok 'forehead'; 
cf. Voty kimes and Zyr kim: śin-kỉm kimes, kimis under U *kuma 'gebeugte, umgestürzte Lage' (entry 16 here).

FP *kulma $>$ Finn kulma $\sim$ Voty kymes $\sim$ Zyr kym (Sammallahti 1988, 552).

39. FP * pelme (*pelme) 'Schmutz' > ?Finn pelme, pelmua-, ?[Voty peń-, (peñm-), peńmal-, ?Zyr pejim, pöim], onomatopoetic, probably that is why it is taken to be uncertain (UEW 2, 728); SSA $(2,333-334)$ takes the Finnic (i.e., Finnish and Karelian) words to be descriptive, without mentioning more distantly related items.

Cf. also Csúcs (2005, 142); Csúcs now takes the base form * pelme to be more likely, "because depalatalisation always took place in Finnish, while palatalisation is sporadic in Permic and mainly occurs next to $i$ " (personal communication).

40. U *pil'me 'dunkel; dunkel werden' > Finn pimeä, Est pime, Voty pelmit, peńmit, pejmît, Zyr pemid, Yur päewd'e, päemće, pewā-, Yen fei, Tvg faemei (UEW 1, 381-382); SSA $(2,367)$ has the same data; EES

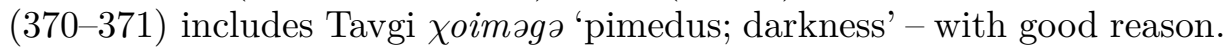

$\mathrm{U}^{*}$ pilmi- 'olla pimeä' (to be dark) > Sam *pâjmâ FP * pilmi- (Janhunen 1981, 237).

$\mathrm{U}^{*}$ pilmitä $>$ Sam ${ }^{*}$ pөmөt $\ddot{a} \sim \mathrm{FU}{ }^{*}$ pilmitä $>$ FP ${ }^{*}$ pilmitä (Sammallahti 1988, 539).

Cf. also Csúcs $(2005,142,150)$.

$$
\text { 5. }{ }^{*}{ }_{\Lambda}
$$

No Hungarian reflex.

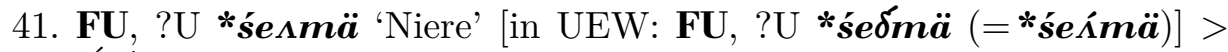

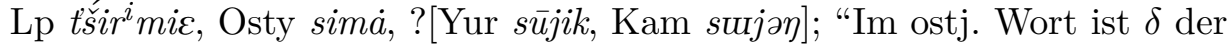
ursprünglichen Konsonantenverbindung $* \delta m$ geschwunden. Vgl. ostj. sĕm 'Herz' finn. sydän (s. *śi $1,472-473)$. There should be $*_{\Lambda}$ rather than $*_{\Lambda}^{*}$ in the reconstructed form as becomes clear from the explanation in page 473 of UEW 1.

$$
\text { 6. } *_{\Lambda 3 m}
$$

The sequence ${ }^{*} \delta 3 m$ - has three reflexes in Hungarian:

24 "In Ostyak, the $\delta$ of the original cluster $* \delta m$ was lost. Cf. Osty sĕm 'Herz' $\sim$ Finn sydän (cf. *śi $\ddot{a}\left(-m_{3}\right)$, * śü $\ddot{a}\left(-m_{3}\right)$ 'Herz' U)." 

(6) ${ }^{*} \Lambda 3 m \stackrel{\nearrow}{\searrow}$
a. $l 3 m$
b. $\left({ }^{*} w>\right) v \sim \overline{3}$
c. $\left(* l_{3} w>\right) l \overline{3}$

(6a) $l 3 m$

42. FU *os 3- m 3 'Schlaf; Traum' > Mord udomo, Cher om, omo, Voty um (umm-), um (unm-), Zyr on (onm-), Osty alam, ulam, Vog ūlam, H álom (UEW 1, 335), derived from FU *osa- 'schlafen' (UEW 1, 335). The Ug

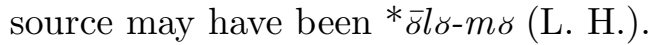

$\mathrm{FU} * a ̊ l m a ̊>\mathrm{FP} *$ alma $\sim \mathrm{Ug} * a ̊ l m a$ (Sammallhti 1988, 542).

Cf. also Csúcs $(2005,137)$.

$$
\text { (6b) }\left({ }^{*} w>\right) v \sim \overline{3}
$$

43. U *sंi $\boldsymbol{i} \ddot{\boldsymbol{a}}(-\boldsymbol{m e})(* \boldsymbol{s} \ddot{\boldsymbol{u}} \boldsymbol{\Lambda} \ddot{\boldsymbol{a}}(-\boldsymbol{m e}))$ 'Herz' > Finn sydän (sydäme-), Est süda, Lp čâdâ, Mord śed'ej, śed’ey, śedi, Cher šüm, Voty śulem, Zyr śélem, Osty sěm, Vog šäm, H szív, R szü, Yur śej, Yen śeo, śeijo, Tavgi śa, śoa, Skp śǐče, śìd', Kam śî, Koib sei, Mot keje-m, Kar zeï-ge, Taigi kei-m (UEW 1, 477; cf. TESz 3, 769); Lp čă'dĕ (gen. ča'ddam, SSA 3, 228); SSA $(3,228)$ and EES (501) list similar data; in the oblique stem of Finn sydän there is - $m m$ - rather than $m$ : e.g., sydämen (genitive) $=$ sydämmen, there are some further examples for similar consonant lengthening, albeit not between second and third but between first and second syllables: Finn amme (< FU *ama- 'schöpfen', UEW 1, 7), tammi (< FW, FP *toma 'Eiche', UEW 2, 798), kämmen (< FU *käme-(ne) 'die flache Hand', UEW 1, 137), but cf. (44) ydin 'Mark' ytimen (genitive).

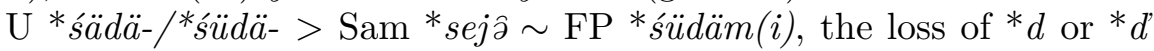
is not normal in $\mathrm{Ug}$ (Janhunen 1981, 258-259). 549)

FU *śüdämi/*śedmi > FP *südämi Ug *sı̀m (Sammallahti 1988,

$$
(6 \mathrm{c})\left({ }^{*} l 3 w>\right) l \overline{3}
$$

44. FU *wis3(-m3) 'Knochenmark, Gehirn' > Finn yty, ydin (ytime-), Est üti (üdi-), Lp âđâ (-đđâm-), Mord udem, Cher wim, Voty vijim, vim, Zyr vem, Osty welam, Vog wälam, wălam, H velö (UEW 1, 572); SSA (3, 188) and EES (635) list similar data. 551).

$\mathrm{FU} *$ wü/ädi/ämi > FP *vüdimi Ug *wädäm (Sammallahti 1988, 
No Hungarian reflex:

45. FU *us 3-mз 'Schlafzelt' > Finn uudin (uutime-), ?[Voty in, (inm-), Zyr von- (vonj-), en, un], Osty olaw, utap, Vog ōmal (UEW 1, 541); "Die perm. Wörter gehören nur dann hierher, wenn $n$ in der vorauszusetzenden Lautentwicklung $* \delta m\left[=\Lambda m\right.$; L. H.] $>{ }^{*} l m>n m(\operatorname{vgl}$. M inm) $>n$ ein Ableitungssuffix ist, vgl. wotj. un, um (unm-, umm-), syrj. on, un (onm-, unm-) 'Schlaf' (s. * $o \delta a-m 3$ 'Schlaf' FU). Schwierigkeiten bereitet, daß im Syrj. kein Stamm *vonm- usw. existiert und der Stamm inm- auch im Wotj. nur in einem Dialekt belegt ist" ${ }^{25}$ (UEW 1, 541); SSA (3, 378-379) presents the same data, though those from Permic languages exhibit some phonological differences: Voty in (inm-), Zyr von (vonj-).

FU *oodimi $>$ FP *oodimi $\sim \mathrm{Ug} * a ̊ d \iota m u$ (Sammallahti 1988, 542).

Cf. also Csúcs $(2005,137)$.

$$
\text { 7. * }{ }^{\prime} m>\mathrm{H} m
$$

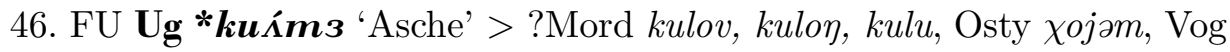
$k \overline{o l}$ วm, H ham- $u$; the Mordvin word can only belong here if its $v, \eta$ is not a derivational suffix but the reflex of the $m$ of the protolanguage cluster

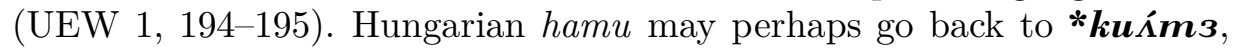

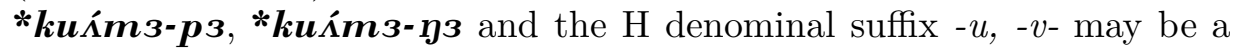
reflex of the protolanguage derivational suffix $*_{-} m_{3} / *_{-}{ }_{3} /{ }^{*}{ }_{-} \eta 3$ (L. H.).

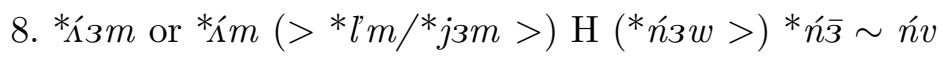

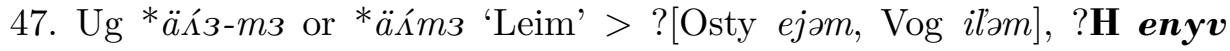
(UEW 2, 835); "Das ung. Wort gehört nur dann hierher, wenn - möglicherweise im Urung. - ein Lautwandel $* j>n y$ oder ${ }^{*} g y>n y$ eingetreten ist" 26 (UEW 2, 835). Csúcs \& Molnár $(2005,69)$ suggest the source form * ä́m3, but this is not very likely because of the vowel-final source suggested in TESz (see right below). I find the Ugric correspondence to be impeccable since the sound change assumed for Proto-Hungarian is totally plausible. "The word probably used to be of the form enyü $\sim$ enyo"

25 "The Permic words only belong here if in the probable sound development $* \delta m$ $[=\Lambda m$; L. H. $]>{ }^{*} l m>n m($ cf. M inm $)>n$ is a derivational suffix, cf. Voty un,

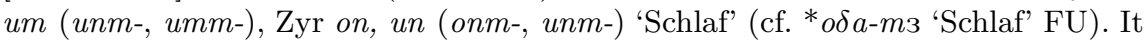
presents some difficulty that in Zyrian there is no stem *vonm- etc., and that the stem inm- is merely attested in a Votyak dialect."

26 "The Hungarian word only belongs here if - perhaps in Proto-Hungarian - there occurred a sound change ${ }^{*} j>n y$ or ${ }^{*} g y>n y . "$ 
$\sim$ enyé; the final vowel is a reflex of the PFU denominal noun forming suffix * ${ }_{-} m$. The form enyv came about by backformation from suffixed enyves 'gluey', enyvet 'glue-acc', etc." (TESz 1, 732; translated from the Hungarian original).

$$
\text { 9. }{ }^{*} r m
$$

No Hungarian reflex.

48. U *järm3 '?Marder, ?Wiesel' > ?Voty d'urmek, ?Skp nä̈rmäk (UEW 1, 94): the vowel is uncertain due to the scanty Samoyedic data and the distant relationship.

49. U*jurma 'tiefe Stelle im Wasser (im Fluß od. See)' $>$ ?Lp jorbme, ?Zyr jir, ?[Sam Yur jor, Yen joðe, Tvg juragâ, Skp kor, Mot ćura] (UEW 1, 105): The Zyrian and Samoyedic words can only belong here if they underwent a ${ }^{*} r m>r$ change, the correspondence is uncertain due to the distant relationship, too.

50. U *karma- 'wollen' > ?Mord karma-, ?[Sam Yur xarwā-, Yen kóma-, Tvg karbútu-, ?Mot choryndžörga-], the Motor word does not certainly belong here because of $\mathrm{rm}$ in it; the etymology is uncertain because of the distant relationship (UEW 1, 128).

51. FW *karm3 (*karp3, *karw3) 'Fliege' > Finn kärpänen, dialectal kärvänen, Est kärbane, Livonian kärmi, Mord karvo, Cher karme (UEW 2, 647-648); the data in SSA $(1,477)$ and in EES (207) are the same.

52. FW *kurma (*kurpa, *kurwa) 'Schnepfe, Waldschnepfe' > Finn kurppa, dialectal kurpa, kurvi, kurmitsa, Est kurp (gen. kurba), kurbiits (gen. kurbiitsa), kurvits (gen. kurvitse), Cher kârmàzak (UEW 2, 676-677); the data in SSA $(1,450)$ and in EES (195) are the same but they take the correspondence to be uncertain due to the onomatopoetic character of the words.

53. FP *kurm 3 'Handvoll' > Mord kurmoś, Cher kormôž, Voty kỉrịm, Zyr kirim (UEW 2, 677).

54. FU *ńarma 'Leiste' > Finn näärvä, Est nääre (gen. näärme), Lp $n \bar{a}_{i} r m e$, Osty ńaram, Vog ńărem (UEW 1,312); the data in SSA $(2,256-$ 257) and in EES (330) are the same.

$\mathrm{FU}$ *ńìmå 'groin, hip' > FP *nérmå (> Lp njar'bme) Ug *nímå (> Vog ńïrmå[?], Osty ńaarem) (Sammallahti 1988, 546). 
55. FU *ńurme 'Wiese' > Finn nurmi, Est nurm, Lp njor'mâa, Osty ńurəm, Vog ńüram (UEW 1, 328); the data in SSA $(2,242-243)$ and in EES (322) are the same.

$\mathrm{FU}{ }^{*}$ ńurmi $>\mathrm{FP}{ }^{*}$ ńurmi $\sim \mathrm{Ug}{ }^{*}$ ńurmı̆ (Sammallahti 1988, 546).

56. FW * orm 3 'Einschnitt an einem Kleidungsstück od. Schuh' > ??Est orm (gen. orma), ??Mord urmać, uncertain semantically and due to the scanty attestation (UEW 2, 722); orm is not listed in EES.

57. FW *parma 'Bremse' > Finn paarma, parma, Est parm, Mord promo, puromo, Cher parm əิ (UEW 2, 724-725); SSA $(2,281)$ links the Volgaic data to the Finnic ones with a question mark, EES (354) takes the Mordvin words to be uncertain, but not the Cheremiss one.

58. FU *perma 'Bremse' > Finn permu, perma, Osty pürəm, purəm (UEW 1, 373-374); SSA $(2,341)$ adds a question mark-probably because it suspects that the Finnish word is a variant of paarma (cf. entry 57).

59. FU *surm 3 'Falte, Runzel; falten, runzeln' > ??[Finn horma, Est hórmane], Mord sorma-, Osty «ŏmər (UEW 1, 452); SSA (1, 173) only lists the Finnic words, EES does not discuss this family of words at all.

60. U *śarma 'Rauchloch des Zeltes' > Vog surèm, Yur sārwa, Yen sáma $a$, ?Kam māzaro; this is correct if Kam $r$ goes back to an earlier *rm (UEW 1, 463).

61. FW *sorme 'Finger' > Finn sormi, Est sõrmi, Lp suor'bmâ -rbm-, Mord sur; in Mordvin, a change ${ }^{*} r m>{ }^{*} r v>r$ occurred (UEW 2, 765); the data in SSA $(3,202)$ and in EES (495) are the same.

62. U *śurme 'wildes Tier' > Lp tš́ñ̂rm, ??Osty türəm, śurəm, Yur sārmik, Yen sâme, Skp suurem, Kar sarma, it is very uncertain whether the Ostyak word belongs here because $t$ and $s$ go back to ${ }^{*} c$ (UEW 1, 490).

63. U * śurme 'Faust' > ?Lp čgr'bmâ -rbm-, ?Yur sormū $k$, uncertain because of the distant relationship (UEW 1, 491).

64. FU *śur(e)-ma 'Tod' > Finn surma, Est surm, Osty sŏrəm, ?Vog sorzm. The Vogul word is perhaps a loanword from Ostyak (UEW 1, 489$490)$; according to $\operatorname{SSA}(3,221)$ the Vogul word is certainly related; this is probably correct, as the dictionary cites a Western dialectal form in addition to the Northern ones; similarly in EES $(489,490)$. On the basis of the reconstructed form of UEW, this entry should have been included under " 12 . U/FU/Ug ${ }^{*} r m$ or ${ }^{*} r 3 m$ ", but according to a correct observation in Csúcs \& Molnár $(2009,52)$ the alternative source form is superfluous. I think this claim is correct, as the Finnic data do not make it necessary to 
assume a word internal $e$, and in the Ob-Ugric languages, the consonant cluster had to be resolved in parallel with the loss of word final vowels, given that final clusters are excluded by the phonotactic constraints of Vogul and Ostyak; hence, only the PFU form * śur-ma can be taken to be correct.

65. FU * tärmä 'Kraft; kräftig' > ?[Finn tarmo, tärmä, ?Lp dar'bmo -bm-], ?Osty täram, ?Vog têrin (UEW 1, 517-518); SSA (3, 272-273) is certain that Finn tarmo and Lp dar'bme belong together but lists the Ob-Ugric data and the $\mathrm{H}$ verb terem 'be produced, appear' with question marks, although the latter does not even figure in UEW and is taken to be of unknown origin in TESz $(3,897)$.

$$
\text { 10. }{ }^{*} r 3 m
$$

No Hungarian reflex.

66. FP *sirs(-m3) (*sür3(-m3)) 'Rotz' > ?Cher šürem, ?[Voty zirim, Zyr zirim], uncertain correspondence (UEW 2, 761).

$$
\text { 11. }{ }^{*} j m>m
$$

67. U*koj(e)-m3 'Mann, Mensch' > ?Voty kum, ?Zyr komi, Vog kom, H hím 'Männchen', Skp kup, kum (UEW 1, 168); cf. Voty kum: viżi kum 'родня, родственник' (собств. 'человек одного рода', vižz 'корень, род') (KESK 132); I do not think it to be justified to doubt that the Votyak and Zyrian data belong here. Cf. also U*koj(e)-ra 'Männchen' (UEW 1, 168-169) > Finn koira, Est koer, Zyr kir, Osty kar, Vog xar, H here, Yur хora, Yen kuða, kura, Tvg kúru, Skp qōr, Kam kora; SSA (385) is right in claiming that the suffixless base forms of these two words could exist independently, as reflected by Lp kuojjă 'man, husband', Osty $k u$,

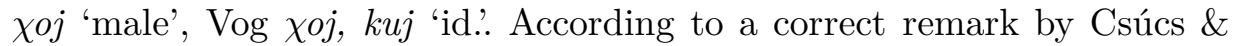
Molnár $(2009,50-51)$, the alternative base forms are superfluous in both entries, given that none of the related words contain an $* e$ between the ${ }^{*} j$ and the ${ }^{*} C$, thus: ${ }^{*} \boldsymbol{k} \boldsymbol{o j}-\boldsymbol{m} \mathbf{3}$ and ${ }^{*} \boldsymbol{k} \boldsymbol{o j}-\boldsymbol{r a}$, but this is irrelevant from the point of view of my conclusions here.

No Hungarian reflex:

68. U *äjmä '(Näh-) Nadel' > Finn äimä, Lp ai'bme -im-, Cher im, ime, Zyr jem, im, Yur ńīpe, Yen nēe, Tvg njāime, ńejmi, Kam ńìmi, Koib neme, Mot ime (UEW 1, 22); the data in SSA $(3,495)$ are the same. $\mathrm{U} * \ddot{a j m m \ddot{a}}>\mathrm{Sam} *$ ejmä $\sim \mathrm{FP} * \ddot{a j j m} \ddot{a}$ (Janhunen 1981, 272). 

$536)$.

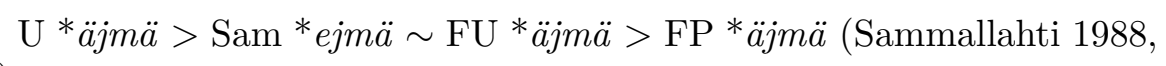

69. FP, ?U *śajma 'aus Holz ausgehöhltes Gefäß; Boot' > Finn saima, seimi, Est söim, Mord śuma, Voty śumik, ?Osty soma, ?Skp somma. "Zum Schwund von $j$ in der Konsonantenverbindung * $j m$ in sämtlichen Sprachen mit Ausnahme der ostseefinnischen vgl. *koje(m3) 'Mann' U, *koje-ra 'Männchen' U. Vgl. auch finn. aitta 'Speicher' mord. E utomo, M utom 'Vorratshaus, Speicher'" 27 (UEW 1, 456); SSA (3, 142-143) accepts the Votyak form, adds a question mark to the Mordvin one, and rejects all the others. EES does not discuss this family of words.

70. FU * śajm 3 'Vertiefung, Senkung (mit einem Teich od. Bach)' > ?Voty śum, ?[Osty sajam, Vog s̄̄jam]. "Die Zusammenstellung ist unter der Voraussetzung akzeptabel, daß $m$ in den obugrischen Wörtern die Fortsetzung der Konsonantenverbindung $\mathrm{FU} * j m$ und kein Ableitungssuffix ist" 28 (UEW 1, 457).

71. FW *wajms 'Herz' > Finn vaimo, Est vaim, Lp vai'bmo -im-, Mord ojme (UEW 2, 809-810); the data in SSA $(3,392)$ and in EES (586) are the same.

72. $\mathrm{FP} * k e j m \ddot{a} /{ }^{*} k e j m a$ or *kej(e)-mä/*kej(e)-ma 'Brunst, Balz' > ?[Finn kiima, kiivas, Est kiim], ?Lp giei'bme -im-, ??[?Voty kemž-, kenž-, ?Zyr kam] (UEW 2, 657-658); the Votyak word can only belong here if its $m$ is original and the $n$ is an assimilated reflex of $m$; the Zyrian word is uncertain because of its vowel, and due to the fact that it is only attested in a single dialect; in Finnic, there sometimes is an $-m-\sim-v$ - correspondence; onomatopoetic; see also FU ${ }^{*} \boldsymbol{k} \boldsymbol{e j} \boldsymbol{e}^{1}\left({ }^{*} k \ddot{8} j \gamma 3\right)$ 'Balz; balzen'(UEW 1, 143); under this, we find Lp gikkâ- $\sim g$, Zyr koj- 'balzen', kut' 'ток, токование', Osty köj- 'balzen', köjam etc. 'Balzstelle', Vog kij- 'balzen', kim etc. 'Balz' ( H kéj 'pleasure'); UEW $(2,658)$ takes it to be possible that the Finnish and Lapp words go back to an early Proto-Finnish form *keima, in which case they derive from $\mathbf{F U}{ }^{*} \boldsymbol{k} \boldsymbol{e j e} \boldsymbol{e}^{1}\left({ }^{*} k \ddot{8} j \gamma 3\right.$ ) 'Balz; balzen' (UEW 2, 658). I think this is likely; base word and derived form were both preserved as in the case of $\mathrm{H} \mathrm{fed} \mathrm{'cover} \mathrm{(vb)'} \mathrm{and} \mathrm{fedél} \mathrm{'cover} \mathrm{(n)'.} \mathrm{-} \mathrm{According} \mathrm{to} \mathrm{SSA} \mathrm{(2,}$ 358) Finnish kiima either corresponds to Lapp giei'bme or, more probably,

\footnotetext{
27 "The $j$ of the cluster $* j m$ disappeared from all languages except Finnic, cf. *koje(m3) 'man' U, *koje-ra 'male' U. Cf. also Finn aitta 'barn' Mord E utomo, M utom 'storehouse, barn'."

28 "The comparison can only be accepted if the $m$ of the Ob-Ugric words is a reflex of the cluster *jm, rather than a derivational suffix."
} 
derives from a verbal root *kii-, also found in Lp gikkât, Zyr kojni, Vog kij-, Osty köj-, H kéj. According to EES (151-152) Finn kiima and Est kiim are both reflexes of a Finnic stem, but perhaps also related to the following: either Lp gihkat or Lp gieibmi, Zyr kojni, Vog kaj-, Osty koj-, and $\mathrm{H}$ kéj. All words mentioned in EES are listed in UEW $(1,143)$ under $\left.{ }^{*} \boldsymbol{k e j e}^{1}{ }^{*}{ }^{*} k \ddot{\delta} j \gamma \gamma_{3}\right)$ 'Balz; balzen' FU; the correspondence between Finn kiima and Vog $k i j$-, $k a j$ - is rejected for phonological reasons by UEW.

\subsection{A historical phonological interpretation of the data base}

In what follows, I present the reflexes of the consonants and consonant clusters under discussion here in the languages that have preserved the words containing them. In Appendix A, I list the reflexes of the individual consonants and consonant clusters in the present-day languages, and in Appendix B, I show which reflex is attested in which words of those languages. I symbolise the degree of certainty of each reflex by a raised figure after the transcription symbol: ${ }^{1}=$ certain, ${ }^{2}=$ uncertain (?), ${ }^{3}=$ very uncertain (??), ${ }^{4}=$ perhaps unlikely (???). These classifications basically reflect the claims found in UEW; sometimes, however, I found it necessary to revise them. In the above entries, the relevant remarks are highlighted by emboldening. In both Appendices, the above entries and the linguistic data in them are referred to by the serial numbers of the entries. An exclamation mark before the serial number refers to the fact that an alternative explanation of the given data is also possible.

Two historical phonological questions remain to be answered:

1. Under what conditions did $\mathrm{PU} / \mathrm{PFU}{ }^{*} m$ survive (as in $e m-i k$ 'suck'), and when did a change ${ }^{*} m(>* w)>v / \overline{3}$ (as in név 'name', nyúl 'rabbit') occur in Hungarian?

2. Under what circumstances is the $\mathrm{PU} / \mathrm{PFU}$ sequence ${ }^{*} C(3) m$ reflected in Hungarian as $C(3) m$ (e.g., álom 'dream'), as $C v$ or $\overline{3}$ (e.g., nyelv 'tongue' $\sim \mathrm{R}$ nè̀lo $=$ nyeló), as $C$ (e.g., sziv 'heart') or $\overline{3}$ (e.g., $\mathrm{R}$ szü 'id.'), and when did it simplify into $3 m$ (e.g., szem 'eye'), into $3 v$ (e.g., név 'name') or into $3 v / \overline{3}$ (e.g., lé lev-et 'liquid nom $\sim$ acc')?

My attempt at answering these two questions follows:

1. In the protolanguage forerunners of words exhibiting ${ }^{*} m>>\mathrm{H} v$ there were no derivational suffixes, whereas in some of the items that retained $m$ there were, perhaps already in the protolanguage (as an alternative). The question is whether the latter situation may have some 
role in the distinction between the two reflexes. The survival of $m$, the "mamial" sound of eme 'mother' and emik 'suck' may be due to the idea of 'sucking'. The items töm 'stuff (vb)' and temet 'bury' are perhaps related to the Cheremiss word by the first criterion if the derivational suffix $t$ was added to the verbal root prior to the change ${ }^{*} m>\mathrm{H}\left({ }^{*} w>\right) v$. One thing seems certain: there is no satisfactory explanation for the double Hungarian reflexes of ${ }^{*}{ }_{3} m 3$. Bárczi attempted to give one:

\footnotetext{
"This Hungarian nasal [i.e. $m$; L. H.] may go back to word internal $\mathrm{FU}{ }^{*} m$, with the proviso that word initial $* m$ - survived in every case, whereas word internally it was only preserved in a subset of cases, typically when it was adjacent to another consonant, e.g., szem 'eye' (cf. e.g., Finnish silmä), három

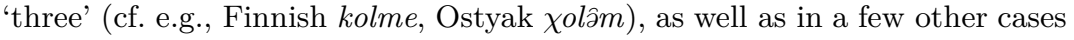
where we may think of ancient dialectal divergence or perhaps regression, e.g., töm (cf., e.g., Cher tem- 'fill'), homorú 'concave' (cf. e.g., Finn kumara 'bent')." (Bárczi 1958, 113-114; translated from the Hungarian original; similarly E. Abaffy 2003, 118)
}

However, dialectal divergence is a mere hypothesis, it cannot be either proved or disproved; at most, we could lend it some credibility on the basis of similar double reflexes in Finnic-Volgaic or Samoyedic languages. On the other hand, the assumption of regression is totally unfounded. The etymologies containing intervocalic ${ }^{*} m$ listed in the above entries are all certain, but it has not proved to be possible (so far?) to detect differences between the sets of forerunners of the Hungarian words containing the two kinds of reflexes ( $m$ and $v$ ) that would give us a rational explanation. Consequently, the resolution of this problem must await further study.

2. With the sequence ${ }^{*} C(3) m$, the situation is slightly different, as Bárczi's words just quoted also suggest: here, $m$ "was only preserved in a subset of cases, typically when it was adjacent to another consonant". In addition, Hungarian is not the sole member of the language family exhibiting such double reflexes, as the entries above show clearly; and researchers were concerned with such dualities quite a few decades ago (Wichmann 1915, 40-44; Uotila 1933, 341-343). It is important to note that reflexes of the sequence ${ }^{*} C(3) m$ are structurally identical in all three Ugric languages, that is, Ugric $C_{3} m$ or $\mathrm{H}^{*} C_{3} w$; this change must have taken place during the time when Ugric peoples still lived together: in Ostyak, both consonantal elements of the original sequence were preserved in eleven words $(26,27,29,35,36,38,42,44,45,46,47)$ and in four words $(41,43,69,70)$ only the nasal (or its reflex) can be found; in Vogul, the corresponding numbers are fourteen $(26,27,28,29,36,42,44,45,46,54$, $55,60,64,65)$ and two $(25,43)$, in Hungarian: seven $(26,27,28,35,36,42$, $44)$ and three $(24,25,43)$. The other languages are less uniform in their 
reflexes. Certain correspondences: in Finnic, the original sequence survived in all cases but one (40), that is, in twent-eight cases $(24,25,26,27,28,29$, $30,31,32,33,34,38,39,43,44,45,51,52,54,55,59,61,64,65,68,69$, $71,72)$; in Lapp, it was invariably preserved in all twenty-four words (24, $25,26,27,28,29,30,31,33,34,38,41,43,44,49,54,55,61,62,63,65,68$, $71,72)$; in Mordvin, the sequence was preserved in sixteen cases, $(24,25$, $27,31,33,37,42,43,44,46,50,51,53,56,59,71)$, whereas in one word (61) it was only the $C$, and in another, (69), it was only the nasal that was preserved; Cheremiss kept the whole sequence in seven cases $(26,33,51$, $52,53,57,66)$ and just the nasal in six $(25,27,42,43,44,68)$; in Votyak, the sequence survived in fourteen words $(25,27,29,30,33,39,40,42,43$, $44,45,48,53,66)$ and was simplified into the nasal in six $(34,67,68,69$, 70, 72); the corresponding Zyrian data are eleven $(25,27,29,30,32,33$, $39,42,43,53,66)$ and six $(34,44,45,67,68,72)$, while in Samoyedic the situation is much more heterogeneous and cannot be summarised in just a few words. Thus: ${ }^{29}$

$\begin{array}{lll}\text { Hungarian } & 7 C(3) m & 3 \mathrm{~m} \\ \text { Vogul } & 14 C(3) m & 2 \mathrm{~m} \\ \text { Ostyak } & 11 C(3) m & 4 \mathrm{~m} \\ \text { Zyrian } & 11 C(3) m & 6 \mathrm{~m} \\ \text { Votyak } & 14 C(3) m & 6 \mathrm{~m} \\ \text { Cheremiss } & 7 C(3) m & 6 \mathrm{~m} \\ \text { Mordvin } & 16 C(3) m & 1 \mathrm{C} \\ \text { Lapp } & 24 C(3) m & 0 \mathrm{~m} \\ \text { Finnic } & 28 C(3) m & 1 \mathrm{~m} \\ \text { Samoyedic } & \text { very heterogeneous }\end{array}$

Károly Rédei, one of the most successful researchers of Permic languages, had the following to say about the history of these consonant clusters; to me it seems that his explanation gives us a key to the interpretation of changes in the rest of the related languages, too:

\footnotetext{
"Let us start from the explanation of Zyr vijim. This would be hard to dissociate from the Zyrian copula: vil- $\sim$ vel-, given that final $-(i) m$ is obviously identical with the participial/nominal suffix Zyr -(e)m, -(e)m, -(i)m, -(i)m $\sim \operatorname{Voty}-(e) m\left(<\mathrm{FU}^{*}{ }_{-} m 3\right)[\ldots]$. But how can we account for the occurrence,

${ }^{29}$ I disregard here the complication that a certain consonant may be reflected, via sound change(s), by another, e.g. $\mathrm{H} C(3) m=C(3) m, C v, C \overline{3}$.
} 
in vijim, of $-j$ - rather than $-l$ - as expected on the basis of the stem vill-? The inferable Proto-Permic predecessor of vijim could be *vilsm3 or *vilm3. Due to the effect of a palatal vowel (Proto-Permic ${ }^{*} \varepsilon$ or $* i$ ) following the word internal $l$, this may have evolved into ${ }^{*}$ vil $m 3$ ( ${ }^{*}$ vilms); and the latter may have given rise to present-day vijim, vijim, etc., via a sound change like *-lm$>-j m-(-j i m,-j i m)$. The line of development sketched here is made probable by the Zyr numeral kujim, kuiim, kuim 'drei', koined 'dritte' ( Voty kuin', stem: kuińm- Finn kolme, etc.). The elements -jim, -im, etc. also go back to an original $*_{-} l m$ - cluster. The $\mathrm{FU} *-l m$ - or $* l m$ - cluster also turned into -jim, -jim in Zyrian as in Zyr pejim, pejim 'Asche' (Voty peń 'id.' Finn pelme 'Stäubchen, Schmutz') [...]." (Rédei 1967, 165; translated from the Hungarian original; cf. also Uotila 1933, 341-343; Itkonen 1954, 283).

" ${ }^{*} l m$ : Die PU-PFU Verbindung ${ }^{*} l m$ ist bereits im Urpermischen $\mathrm{zu}{ }^{*} n m$ geworden. Die nach diesem Lautwandel in die Sprache aufgenommenen Wörter mit $l m$ haben diese Lautverbindung entweder unverändert beibehalten oder sie hat sich anders entwickelt. Z. B.: syrj. P ulme 'Apfel' $\sim$ wotj. ulmo id. < mittelbulg. *ålma oder *olma (> tschuw. ulma); [syrj.] S kelmi-, V kevmi-, kemmi-, V P kejmi- 'beten, bitten' (das mi ist ein Ableitungssuffix)."30

(Rédei 1988b, 360)

"*lm: Das urpermische ${ }^{*} l m$ hat sich in den permischen Sprachen in verschiedenen Richtungen entwickelt. Im Syrjänischen haben sich die Lautwandel $l m>{ }^{*} j m$, jim, bzw. ${ }^{*} l m>j m>m$ vollzogen. Im Wotjakischen wurde das * $l m$ dialektal bewahrt, in den meisten Dialekten ist es aber regelmäßig in $j m$ bzw. ńm übergegangen. Die Assimilation $* l m>n ́ m$ ist im Wotjakischen eine verhältnismäßig junge Erscheinung. Z. B.: [27] syrj. kujim, PO kvim 'drei', kojmed, P kujmet, kujime•t 'dritte', wotj. kwiń (kwińm-) 'drei', kwińmeti, G kwińme $\bullet i$ 'dritte' ( finn. kolme); syrj. [40] pemid, P pemit, PO pi•met, wotj. S pelmit, MU M pejmit, J G peńmit 'finster' ( finn. pimeä), [39] syrj. pejim, Peč. peim, wotj. peń (peńm-, peń-) 'Asche', peńmal- 'mit Asche bestreuen, beschmutzen'. In den Zahlwörtern syrj. komin, wotj. kwamin 'dreißig' ( $<$ urpermisch ${ }^{*}$ kuolm-min $<{ }^{*}$ kolm-min $)$ scheint das ${ }^{*} l$ schon im Urpermischen eingebüßt worden zu sein: $* l m m>m m>m . "$.

(idem.)

30 " $* l m$ : The PU-PFU cluster $* l m$ turned into ${ }^{*} n m$ already in Proto-Permic. Loanwords that entered the language after this change had taken place either kept this cluster unchanged or underwent some other change. E.g. Zyr P ulme 'Apfel' Voty ulmo 'id.' < Middle Bulgarian *alma or *olma (> Chuvash ulma); [Zyr] S kelmi-, V kevmi-, kemmi-, V P kejmi- 'beten, bitten' (where mi is a derivational suffix)."

31 "* $l m$ : Proto-Permic * $\operatorname{lm}$ developed in diverse directions in the various Permic languages. In Zyrian, the sound changes $l m>*^{*} j m$, jim, and ${ }^{*} l m>j m>m$ occurred. In Votyak $* v l m$ remained in certain dialects but became $j m$ or $n m$ in most of them. The Votyak assimilation $* l m>n$ is a relatively recent phenomenon. E.g. [27] Zyr kujim, PO kvim 'drei', kojmed, P kujmet, kujime •t 'dritte', Voty kwin (kwińm-) 'drei', kwińmeti, G kwinme•ti 'dritte' ( Finn kolme); Zyr [40] pemid, P pemit, PO pi॰met, Voty S pelmit, MU M pejmit, J G peńmit 'finster' ( Finn pimeä), [39] Zyr 


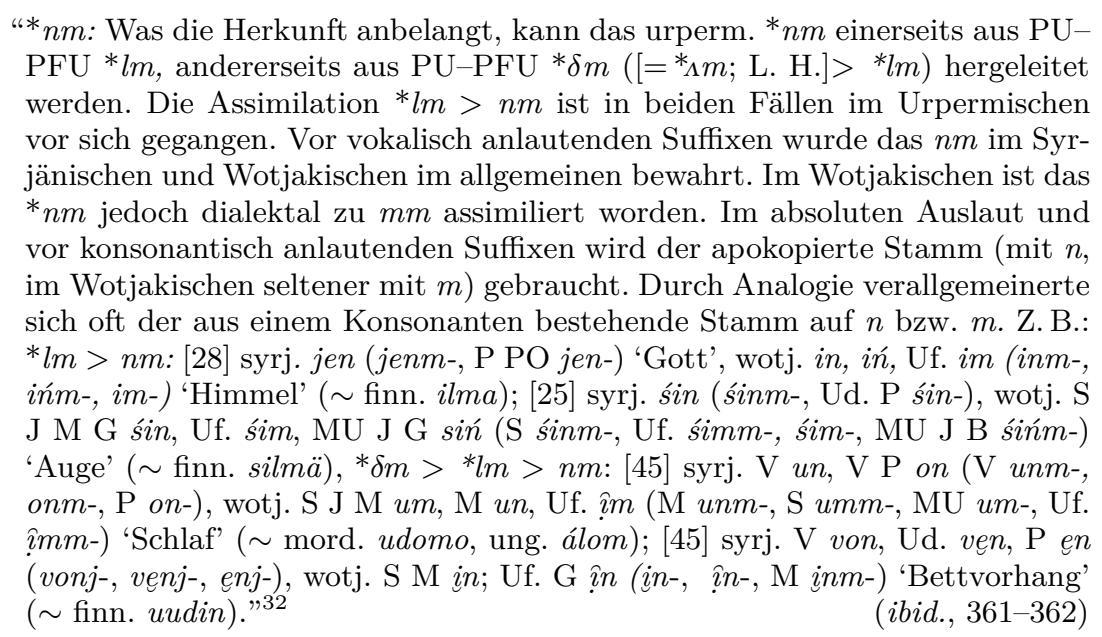

The essence of this explanation, then, is that the lateral immediately preceding the ${ }^{*} m$ was palatalised (if it was not palatal to begin with), then it turned into a semivowel, and then it often partially assimilated to the

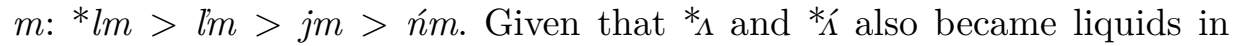
Permic ( $l$ and $l$, respectively), the clusters of these with $m$ underwent the same changes $(42,44, ? 45)$. The change ${ }^{*} l m>{ }^{*} j m$ started already in Proto-Permic: (27) Voty kwiń (kwińm-) 'three', Zyr kujim, kvim 'id.' (cf. Finn kolme 'three'), Voty kwamin 'thirty', Zyr komin 'id.' (<*kuolm-min 'id.' < Proto-Permic *kolm-min); in the numeral meaning 'three' and in

pejim, Peč. peim, Voty peń (peńm-, peń-) 'Asche', peńmal- 'mit Asche bestreuen, beschmutzen'. In the numerals Zyr komin, Voty kwamin 'dreißig' (< Proto-Permic *kuolm-min $<{ }^{*}$ kolm-min) the ${ }^{*} l$ ' seems to have been lost already in Proto-Permic: $* l m m>m m>m$."

32 "* $n m$ : As far as its origin is concerned, Proto-Permic *nm partly the reflects PUPFU cluster ${ }^{*} l m$, and partly PU-PFU $*^{*} \delta m\left(\left[={ }^{*}{ }_{\Lambda} m\right.\right.$; L. H. $\left.]>*^{*} l m\right)$. The assimilation $* l m>n$ m took place in Proto-Permic in both cases. Before vowel-initial suffixes, $n m$ was in general preserved in Zyrian and in Votyak, although in Votyak in some dialects it assimilated into $\mathrm{mm}$. Word finally before a pause, as well as before consonant-initial suffixes, the stem is used in its shorter form (ending in $n$, in Votyak less frequently in $m$ ). However, in many cases, the $n$ or $m$-final stem was analogically extended to all environments. E.g., ${ }^{*} l m>n m$ : [28] Zyr jen (jenm-, P PO jen-) 'Gott', Voty in, iń, Uf im (inm-, ińm-, im-) 'Himmel' ( Finn ilma); [25] Zyr śin (śinm-, Ud P śin-), Voty S J M G śin, Uf śim, MU J G siń (S śinm-, Uf śimm-, śim-, MU J B śińm-) 'Auge' ( Finn silmä), ${ }^{*} \delta m>{ }^{*} l m>n m$ : [45] Zyr V un, V P on (V unm-, onm-, $\mathrm{P}$ on-), Voty S J M um, $\mathrm{M}$ un, Uf $\imath m(\mathrm{M}$ unm-, S umm-, MU um-, Uf ?̂mm-) 'Schlaf' ( Mord udomo, H álom); [45] Zyr V von, Ud ven, $\mathrm{P}$ egn (vonj-, venj-, enj-), Voty S M in; Uf G ?̊n (i̊n-, ? $n-$, M inm-) 'Bettvorhang' ( Finn uudin)." 
its derivatives the sound change ${ }^{*} l m m>{ }^{*} m m>m$ may have occurred in Proto-Permic already. Votyak shows a similar change in (40) U*pil'me > Voty pelmit, pejmit, peńmit 'finster', peń (peńm-, peñ-) 'Asche', peńmal'mit Asche bestreuen, beschmutzen' ( Zyr pejim, peim 'Asche', pemid, pemit, pi•met; cf. Finn pimeä). However, there are two ancient words that had the sequence ${ }^{*} j(3) m$ but do not provide evidence for Proto-Permic ${ }^{*} j m>$ Votyak nm: (67) U *koje-m3 (UEW claims that this item has somewhat uncertain reflexes in Votyak and Zyrian, though it seems to me

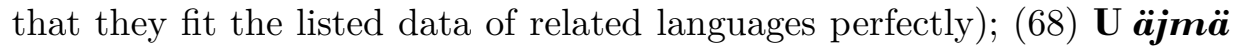
only has a reflex in Zyrian and even that fails to have a stem alternant in $n m$ (Rédei 1988a, 360). There is nothing strange about that: "Es kommt häufig vor, daß der vereinfachte Stamm (im absoluten Auslaut) auch in die intervokalische Stellung eindringt, d. h. die Konsonantenverbindung wird aufgehoben. Z. B.: [25] syrj. śin Instr. śinmenn, aber P śin $\sim$ śinęn. Die Verallgemeinerung des einfachen Konsonanten kommt bei den Nominalstämmen öfters vor als bei den Verbalstämmen"33 (op.cit., 357); the other possible reason is a chronological one: the change U/FU ${ }^{*} j m>$ ProtoPermic ${ }^{*} m$ preceded the changes of $\mathrm{U} / \mathrm{FU}{ }^{*} C(3) m$ clusters in which the ${ }^{*} C$ was not ${ }^{*} j$.

This change must have continued in the independent lives of the Permic languages, as shown unambiguously by the following Zyrian forms: "S kelmi-, V kevmi-, kemmi-, V P kejmi- 'beten, bitten' (das mi ist ein Ableitungssuffix)" [... is a derivational suffix] (Rédei 1988b, 360).

Finnic reflexes of (40) U * pilme 'dunkel; dunkel werden' (Finn pimeä, Est pime) also confirm the change $l>j$ (though subsequently this $j$ was lost without a trace in this group of languages). In the case of (39) FP *pelme (*pelme) 'Schmutz', Csúcs now takes the base form * pelme to be more likely, "because depalatalisation always took place in Finnish, while palatalisation is sporadic in Permic and mainly occurs next to $i$ " (personal communication); I find this interpretation plausible.

I take it to be likely that in Cheremiss $(25,27,42,43,44)$ and in Ugric $(24,25,43)$, too, the emergence of the cluster that later simplified into a nasal was due to a similar series of changes.

We can assume changes like ${ }^{*} l m>{ }^{*} l m(25,30),{ }^{*} l m>*^{*} l m(40),{ }^{*}{ }{ }_{m}$ $>{ }^{*} \operatorname{lm}(? 41,43)$ in Proto-Samoyedic, too, and the fate of * $l$ apparently took the same course in both Permic and Hungarian: "Silben schließendes

\footnotetext{
33 "It often happens that the simplified stem (occurring before a pause) invades the intervocalic position, that is, the cluster is simplified there, too. E.g. [25] Zyr śin instrumental śinmen, but $\mathrm{P}$ śin $\sim$ śinen. The generalisation of the form containing a single consonant happens more frequently in nominal than in verbal stems."
} 
$* j$ wurde mit vorangehendem Vokal kontrahiert, infolge der Kontraktion entstand ein langer Vokal, mitunter ein Diphthong"34 (Mikola 2004, 40). In Samoyedic, ${ }^{*} l>j$ took place in other positions (word initially and word finally), too, cf. Finn tule- 'come' $\sim$ Sam ${ }^{*} t o j-<$ U *toli-, Finn tuli 'fire' $\sim$ Sam ${ }^{*} t u j<\mathrm{U} * t u l i$, Sam *uj 'seiväs, kotapuu; rod, tent-pole' < U*uli (Janhunen 1981, 231, 233), and the same happened to *d' (=UEW: * $\delta$ $={ }^{*}$; L. H.) in all positions (op. cit. 250). For Samoyedic, cf. also Setälä (1912, 17-18).

After a high labial vowel, preconsonantal $l$ was also realised as $j$ in my own native dialect of Hungarian, too: e.g., tanujnyi 'to learn', kiderüjt 'it turned out'.

According to Rédei's plausible explanation, the changes of *l, ${ }^{*} l,{ }^{*} \delta$ $\left({ }^{*} \delta\right)\left[=*_{\Lambda}\left(*^{\prime}\right)\right]$ took place in the clusters ${ }^{*} l m,{ }^{*} l m,{ }^{*} \delta m\left({ }^{*} \delta m\right)\left[=*_{\Lambda} m\right.$ $\left({ }^{*} \mathrm{i} m\right)$ ], at least in Proto-Permic. However, some of these Proto-Permic clusters go back to $\mathrm{U} / \mathrm{FU} / \mathrm{Ug}{ }^{*} l 3 m,{ }^{*}{ }^{*} m,{ }_{\Lambda 3 m}\left({ }^{*}{ }_{\Lambda} 3 m\right)$. The reason must be that the vowel was elided in inflectional forms, and in some cases the * Cm cluster was resolved by a vowel (3) partly already in Proto-Ugric, and partly in the Ugric languages, that is: ${ }^{*} \mathrm{C} 3 m>C m(43,46)$, and ${ }^{*} \mathrm{Cm}>$ $C_{3 m}(26,27,28,29,38)$. Which stem alternant was then consolidated in the nominative was a matter of the period when the individual languages carried on their separate lives. This is true of the other languages, as well.

One of the most controversial issues arising from the facts discussed in this paper is perhaps the question of when and why the $C$ disappeared from the sequence ${ }^{*} C 3 m$ and/or ${ }^{*} C(3) m$ if it was ${ }^{*} l$, or $*_{\Lambda}$, or $*_{\Lambda}^{*}$. The answer could perhaps be that the possibility mainly arose whenever that ${ }^{*} C$ became ${ }^{*} j$, that is, a semivowel. This is suggested by reflexes of reconstructed protolanguage * jm (UEW) (cf. Salánki 1991, 168-171) and by Rédei's claims concerning Permic languages (referred to above), as well as by the Hungarian reflexes of the original $* j(3) m$ sequences, e.g., [67] U *koj(e)-m3 'Mann, Mensch' > Voty kum, Zyr komi, Vog kom, H him, Skp

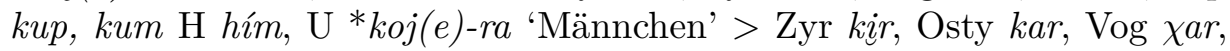

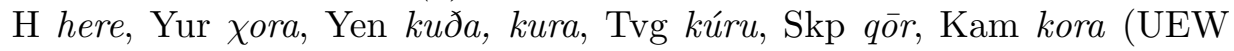
1, 168-169). Similar Hungarian items include [46] FU Ug *kuর́m3 'Asche'

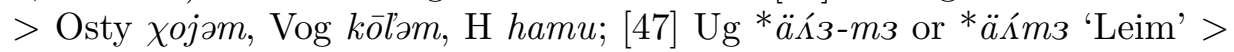
Osty ejam, Vog ilam, $\mathrm{H}$ enyv; in the latter, partial assimilation of the kind $\left(*_{\Lambda}>\right) *_{j}>n(=n y)$ took place before (or instead of) $*_{j}>\emptyset$.

34 "Syllable final $*_{j}$ merged with the preceding vowel, and the contraction resulted in a long vowel or sometimes in a diphthong." 
Similar changes under comparable circumstances can be seen to have occurred in other Uralic languages as well, e.g., [40] U* pilme 'dunkel; dunkel werden' > Finn pimeä, Est pime, Voty pelmit, peńmit, pejmît, Zyr

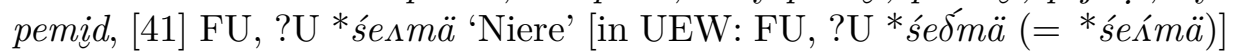
$>$ Osty simá, but naturally they did not take place in each and every member of each and every etymological family of words, e.g., [39] FP * pelme (*pelme) 'Schmutz' > ?Finn pelme, pelmua-, ?[Voty peń-, (peńm-), peńmal-, ?Zyr pejim, pöim].

In several cases, partial assimilation (palatalisation) may have occurred due to the palatalised initial consonant in Pre-Hungarian or in Proto-Hungarian, and also in some other related languages; or due to further partial assimilation the $* j$ may have produced nasal reflexes: ${ }^{*} C(=* l$, $\left.*_{\Lambda}\right)>{ }^{*} \dot{C}\left(={ }^{*} l, *_{\Lambda}^{\prime}\right)>{ }^{*} j\left(>\emptyset /{ }^{*} n\right.$, and then $\left.{ }^{*} \dot{n}>n^{\prime} \gtrsim n\right)$, e.g., [24] FU *cóolme 'Knoten, Bündel; binden' (>*ćolme) $>\mathrm{H}$ csom-ó; [25] U * śilmä 'Auge' $(>*$ śilmä) > Voty śin (śinm-), śin (śinm-), Zyr śin (śinm-), Osty sem, Vog sam, H szem; [43] U *śiı ä(-me) (> *süǘ̈̈(-me) > *sín̈ä(-me) $\left({ }^{*} s \ddot{u} \Lambda \ddot{a}(-m e)\right)>$ 'Herz' > Cher šüm, Osty sĕm, Vog šäm, H szív, R szü. But such partial assimilation did not always take place, and consequently neither $\operatorname{did}{ }^{*} C>{ }^{*} j>{ }^{*} \emptyset$ : [26] FU * nälmä 'Zunge' $>$ Cher jalmə, Osty

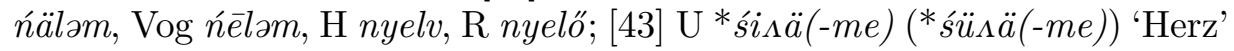
$>$ Voty śulem, Zyr śelem.

On the other hand, when ${ }^{*} C$ was not ${ }^{*} j$, or $* l$, or $*_{\Lambda}^{*}$, or the conditions for the palatalisation ${ }^{*} C\left(={ }^{*} l, *_{\Lambda}\right)>{ }^{*} C\left(=*^{*} l\right.$, $\left.*_{\Lambda}^{\prime}\right)$ were not present, the $C$ remained intact in Hungarian (and perhaps in some other languages, too), e.g., [28] Ug *wolm3 'Blei' > Vog wōlam, H ólom; [35] Ug *ala-ma (*al3-m3) 'Einlage im Schuh (aus Heu)' > Osty isəm, H alom; [36] Ug *äls (*äl(3)-m3) 'andere Seite' > Osty äV əm, Vog äləm, H elv, elü, el. Of course, even the lack of the change was not exceptionless, given that in some related languages we can witness sporadic changes of the ${ }^{*} C\left(={ }^{*} l\right.$, $\left.*_{\Lambda}\right)>j>\emptyset$ type: [42] FU *on3-m3 'Schlaf; Traum' > Cher om, omo, Voty um (umm-), um (unm-), Zyr on (onm-), Osty alam, ulam, Vog ūlam, $\mathrm{H}$ álom; [44] FU *wis3(-m3) 'Knochenmark, Gehirn' > Cher wim, Voty vijim, vim, Zyr vem, Osty weləm, Vog wälam, wālam, $\mathrm{H}$ velö.

In sum, although the reason of the dual reflexes of PU/PFU intervocalic ${ }^{*} m$ in Hungarian $\left(m,{ }^{*} w\right)$ has not been found (yet?), in the case of the sequences ${ }^{*} C(3) m 3$ such a rational explanation does exist. 


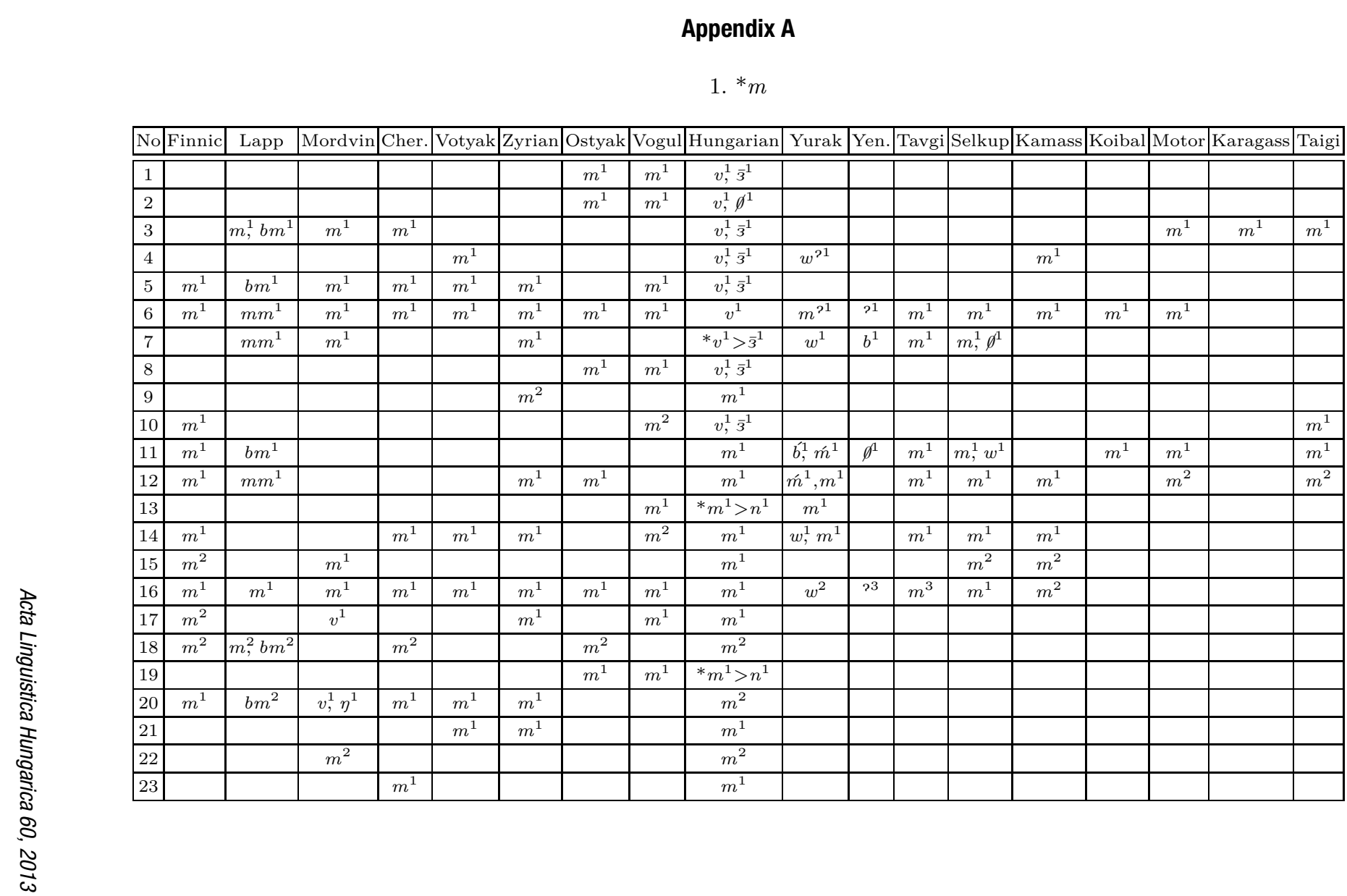




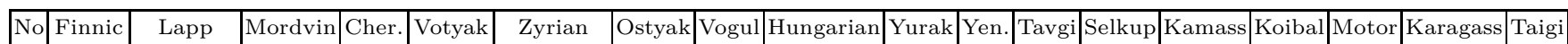

\begin{tabular}{|c|c|c|c|c|c|c|c|c|c|c|c|c|c|c|c|c|c|c|}
\hline \begin{tabular}{|l|}
24 \\
\end{tabular} & $l m^{1}$ & $l^{\prime} b m^{1}$ & $l m^{1}$ & & & & & & $m^{1}$ & & & & & & & & & \\
\hline 25 & $l m^{1}$ & $l^{\prime} b m^{1}$ & $l m^{1}$ & $\begin{array}{l}n^{1} \\
(: n z\end{array}$ & $\mid \begin{array}{l}n=1 \\
1 \\
n^{1}, n m^{1} \\
n\end{array}$ & $n^{1} n m^{1}$ & $m^{1}$ & $m^{1}$ & $m^{1}$ & $w^{1}, m^{1}$ & $j^{1}$ & $j m^{1}$ & $j^{1}$ & $m^{1}$ & $m^{1}$ & $m^{1}$ & $m^{1}$ & $m^{1}$ \\
\hline 26 & $\begin{array}{l}l^{l m^{2}} \\
(l v, l p)\end{array}$ & $l^{\prime} b m^{1}$ & & $l m^{1}$ & & & $l 3 m^{1}$ & $l 3 m^{1}$ & $l v^{1} \sim l 3^{1}$ & & & & & & & & & \\
\hline 27 & $l m^{1}$ & $l^{\prime} b m^{1}$ & $l m^{1}$ & $m^{1}$ & $n_{n}^{1} n^{n} m^{1}$ & j3m, $m^{1}$ & $l 3 m^{1}$ & $r 3 m^{1}$ & $r 3 m^{1}$ & & & & & & & & & \\
\hline 28 & & & & & & & & $l 3 m^{1}$ & $l 3 m^{1}$ & & & & & & & & & \\
\hline 29 & $l m^{1}$ & $l^{\prime} b m^{1}$ & & & 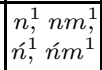 & $n^{1}, n m^{1}$ & $l 3 m^{1}$ & $l 3 m^{1}$ & & & & & & & & & & \\
\hline 30 & $l m^{2}$ & $l^{\prime} b m^{2}$ & & & $n^{2}, n m^{2}$ & $n^{2} n m^{2}$ & & & & & & & & & & & & \\
\hline 31 & $l m^{1}$ & $l m^{2}, l^{\prime} b m^{2}$ & $l m^{1}$ & & & & & & & $l \dot{m}^{1}$ & $m^{1}$ & & & $l m^{1}$ & & & & \\
\hline 32 & $l m^{2}$ & & & & & $\begin{array}{c}n^{2} \\
\left(<?^{*} n m^{2}\right)\end{array}$ & & & & & & & & & & & & \\
\hline 33 . & $l m^{1}$ & $l m^{1}, l^{\prime} b m^{1}$ & $l m^{1}$ & $l m^{1}$ & $n, n m^{1}$ & $n^{1} n m^{1}$ & & & & & & & & & & & & \\
\hline 34 & $l m^{2}$ & $l^{\prime} b m^{2}$ & & & $m^{2}$ & $n^{2}$ & & & & & & & & & & & & \\
\hline
\end{tabular}

3. ${ }^{*} l 3 m$

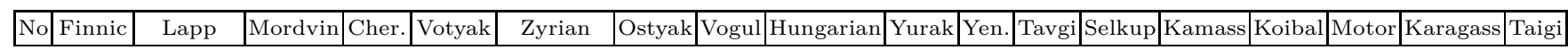

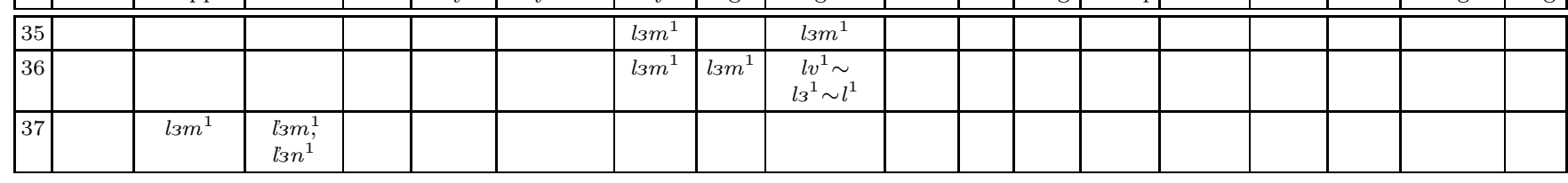




\section{4. ${ }^{*} l m$}

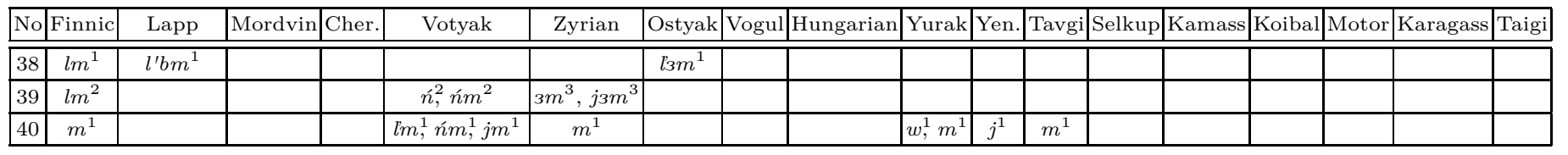

5. ${ }^{*} m$

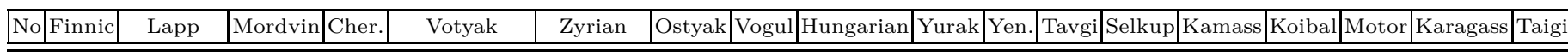

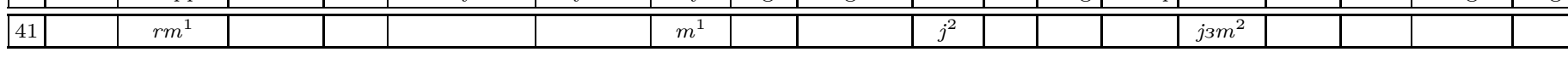

6. ${ }^{*}{ }_{43 m}$

\begin{tabular}{|c|c|c|c|c|c|c|c|c|c|c|c|c|c|c|c|c|c|c|}
\hline No & Finnic & Lapp & Mordvin & Cher. & Votyak & Zyrian & Ostyak & Vogul & Hungarian & Yurak & Yen. & Tavgi & Selkup & Kamass & Koibal & Motor & Karagass & Taigi \\
\hline 42 & & & " $d_{3 m^{1}}$ & $\overline{m^{1}}$ & $\overline{m m^{1} n m^{1}, \mathrm{~mm}^{1}}$ & $\overline{\overline{n^{1}, n m^{1}}}$ & llsmin & ll3m & $\begin{array}{ll}l_{3} m^{1} \\
\end{array}$ & & & & & & & & & \\
\hline 43 & $d_{33 m^{1}}$ & $\begin{array}{c}{ }^{\prime d d m_{3}^{1}}, \\
m^{1}\end{array}$ & $\begin{array}{c}d_{33 j}^{1} \\
\left.d_{3} \eta^{1}\right)^{2}\end{array}$ & $m^{1}$ & $l_{3 m^{1}}$ & $l_{3 m^{1}}$ & $m^{1}$ & $m^{1}$ & $v^{1}, \overline{3}^{1}$ & $j^{1}$ & $\overline{j^{1}, \emptyset^{1}}$ & $\emptyset^{1}$ & $\check{c}^{1}, d^{1}$ & $\emptyset^{1}$ & $j^{1}$ & $j^{1}$ & $j^{1}$ & $j^{1}$ \\
\hline 44 & $d_{3} m^{1}$ & $\overline{d d} 3 m^{1}, m$ & $d_{3 m^{1}}$ & $m^{1}$ & $j 3 m^{1} m^{1}$ & $m^{1}$ & $l 3 m^{1}$ & $l_{33 m^{1}}$ & $l \overline{3}^{-1}$ & & & & & & & & & \\
\hline 45 & $d_{3} m^{1}$ & & & & $n_{,}^{2} n m^{2}$ & $n_{, 2}^{2} n j^{2}$ & $l_{3} C^{1}$ & $m 3 l^{1}$ & & & & & & & & & & \\
\hline
\end{tabular}

7. ${ }_{4}^{*} m$

8. ${ }^{*}{ }_{1} 3 m$ or ${ }^{*}{ }_{1} m$

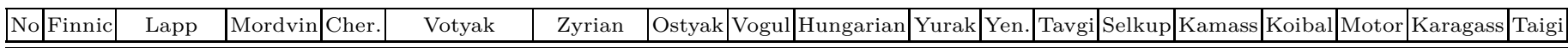

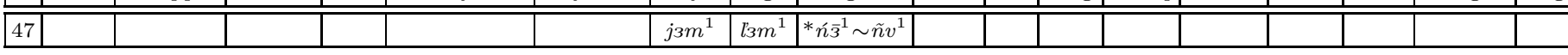




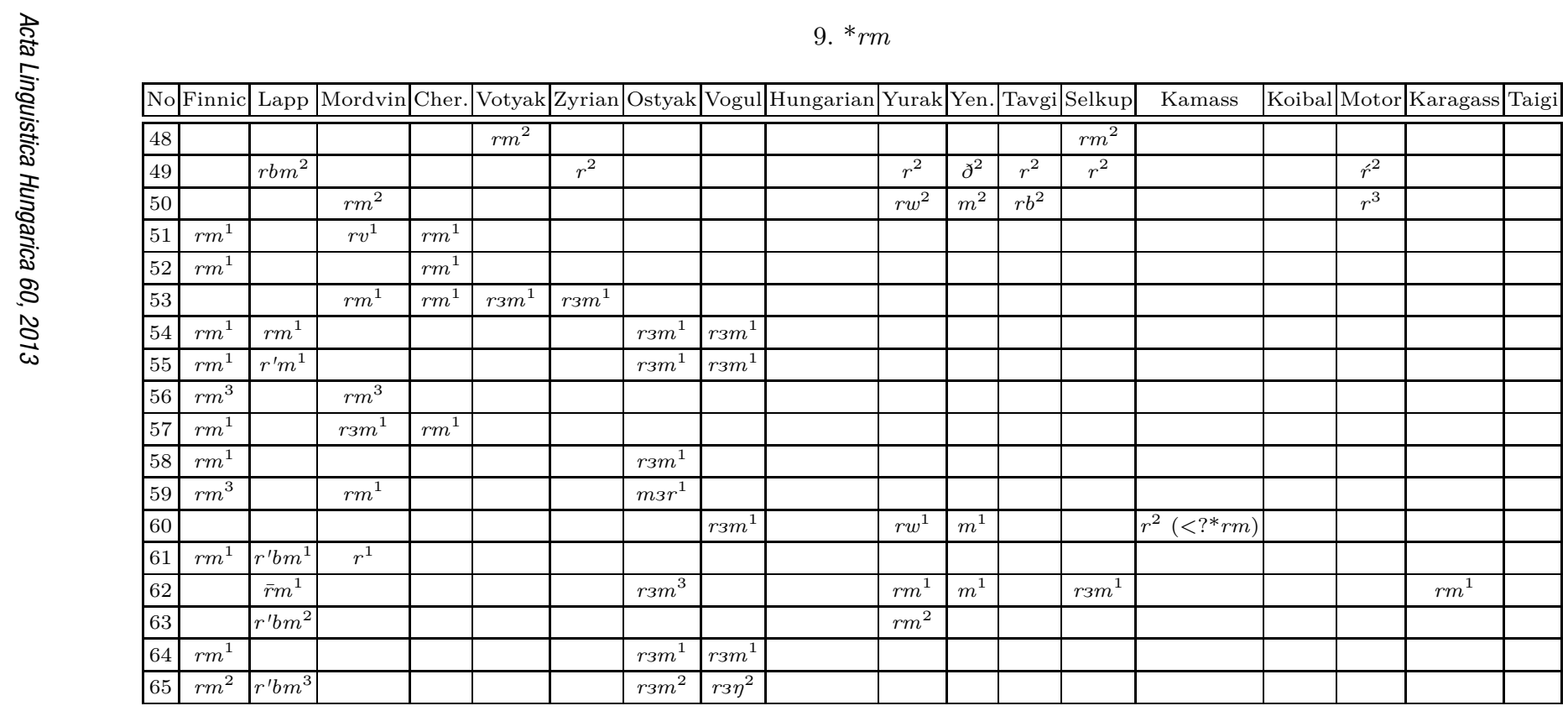


10. ${ }^{*} r 3 m$

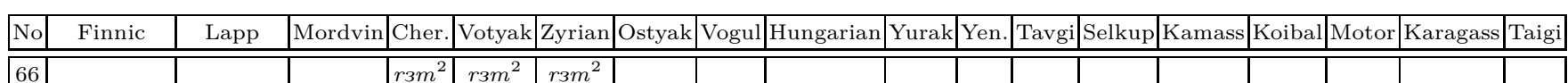

11. ${ }^{*} j m$

\begin{tabular}{|c|c|c|c|c|c|c|c|c|c|c|c|c|c|c|c|c|c|c|}
\hline Finnic & Lapp & Mordvin & Cher. & Votyal & Zyrian & Ostyak & Vogu & Hungarian & Yurak & Yen. & Tavg & Selku & & nass | & Koiba & Motor & Karagass & Faigi \\
\hline 87 & & & & $m^{1}$ & $m^{1}$ & & $m^{1}$ & $m^{1}$ & & & & $p, m$ & & & & & & \\
\hline$i^{i m^{1}}(j m)$ & $i^{\prime} b m^{1}$ & & $m^{1}$ & & $m^{1}$ & & & & $p^{1}$ & $\emptyset^{1}$ & $j m^{1}$ & & & $n^{1}$ & $m^{1}$ & $m^{1}$ & & \\
\hline$i m^{1}(=j m)$ & & $m^{1}$ & & $m^{1}$ & & $m^{2}$ & & & & & & $m m^{2}$ & & & & & & \\
\hline 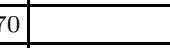 & & & & $m^{2}$ & & $m^{2}$ & $m^{2}$ & & & & & & & & & & & \\
\hline$i m^{1}(=j m)$ & $i^{\prime} b m^{1} i m^{1}$ & $j m^{1}$ & & & & & & & & & & & & & & & & \\
\hline \begin{tabular}{l|l|}
72 & $3 m^{2}$ \\
\end{tabular} & $i^{\prime} b m^{2}{ }^{2} \mathrm{~m}^{2}$ & & & $m^{4}$ & $m^{4}$ & & & & & & & & & & & & & \\
\hline
\end{tabular}




\section{Appendix B}

$$
\text { 1. }{ }^{*} m
$$

\begin{tabular}{|c|c|c|c|}
\hline Language & Reflexes & Serial numbers of entries & Nr. of occurrences \\
\hline \multirow[t]{2}{*}{ Finnic } & $m^{1}$ & $5,6,10,11,12,14,16,20$ & 8 \\
\hline & $m^{2}$ & $15,17,18$ & 3 \\
\hline \multirow[t]{6}{*}{ Lapp } & $m^{1}$ & 16 & 1 \\
\hline & $m^{1} b m^{1}$ & 3 & 1 \\
\hline & $b m^{1}$ & 5,11 & 2 \\
\hline & $m m^{1}$ & $6,7,12$ & 3 \\
\hline & $m^{2} b m^{2}$ & 18 & 1 \\
\hline & $b m^{2}$ & 20 & 1 \\
\hline \multirow[t]{4}{*}{ Mordvin } & $m^{1}$ & $3,5,6,7,15,16$ & 6 \\
\hline & $m^{2}$ & 22 & 1 \\
\hline & $v^{1}$ & 17 & 1 \\
\hline & $v^{1} \eta^{1}$ & 20 & 1 \\
\hline \multirow[t]{2}{*}{ Cheremiss } & $m^{1}$ & $3,5,6,14,16,20,23$ & 7 \\
\hline & $m^{2}$ & 18 & 1 \\
\hline Votyak & $m^{1}$ & $4,5,6,14,16,20,21$ & 7 \\
\hline \multirow[t]{2}{*}{ Zyrian } & $m^{1}$ & $5,6,7,12,14,16,17,20,21$ & 9 \\
\hline & $m^{2}$ & 9 & 1 \\
\hline \multirow[t]{2}{*}{ Ostyak } & $m^{1}$ & $1,2,6,8,12,16,19$ & 7 \\
\hline & $m^{2}$ & 18 & 1 \\
\hline \multirow[t]{3}{*}{ Vogul } & $m^{1}$ & $1,5,6,8,13,16,17,19$ & 8 \\
\hline & $m^{2}$ & 10,14 & 2 \\
\hline & $n^{1}$ & 2 & 1 \\
\hline \multirow[t]{6}{*}{ Hungarian } & $m^{1}$ & $9,11,12,14,15,16,17,21,23$ & 9 \\
\hline & $* m^{1}>n^{1}$ & 13,19 & 2 \\
\hline & $m^{2}$ & $18,20,22$ & 3 \\
\hline & $v^{1} \overline{3}^{1}$ & $1,3,4,5,6,8,10$ & 7 \\
\hline & $v_{,}^{1} \emptyset^{1}$ & 2 & 1 \\
\hline & $* v^{1}>\overline{3}^{1}$ & 7 & 1 \\
\hline \multirow[t]{8}{*}{ Yurak } & $m^{1}$ & 13 & 1 \\
\hline & $m^{1} m^{1}$ & 12 & 1 \\
\hline & $m^{21}$ & 6 & 1 \\
\hline & $b^{1} m^{1}$ & 11 & 1 \\
\hline & $w^{1}$ & 7 & 1 \\
\hline & $w^{21}$ & 4 & 1 \\
\hline & $w_{,}^{1} m^{1}$ & 14 & 1 \\
\hline & $w^{2}$ & 16 & 1 \\
\hline \multirow[t]{4}{*}{ Yeniseian } & $b^{1}$ & 7 & 1 \\
\hline & $P 1$ & 6 & 1 \\
\hline & 23 & 16 & 1 \\
\hline & $\emptyset^{1}$ & 11 & 1 \\
\hline \multirow[t]{2}{*}{ Tavgi } & $m^{1}$ & $6,7,11,12,14$ & 5 \\
\hline & $m^{3}$ & 16 & 1 \\
\hline
\end{tabular}




\begin{tabular}{|l|l|l|c|}
\hline Language & Reflexes & Serial numbers of entries & Nr. of occurrences \\
\hline \hline \multirow{5}{*}{ Selkup } & $m^{1}$ & $6,12,14,16$ & 4 \\
\cline { 2 - 4 } & $m^{1}, w^{1}$ & 11 & 1 \\
\cline { 2 - 4 } & $m^{1}, \emptyset^{1}$ & 7 & 1 \\
\cline { 2 - 4 } & $m^{2}$ & 15 & 1 \\
\hline \multirow{3}{*}{ Kamass } & $m^{1}$ & $4,6,12,14$ & 4 \\
\cline { 2 - 4 } & $m^{2}$ & 15,16 & 2 \\
\hline Koibal & $m^{1}$ & 6,11 & 2 \\
\hline \multirow{3}{*}{ Motor } & $m^{1}$ & $3,6,11$ & 1 \\
\cline { 2 - 4 } & $m^{2}$ & 12 & 3 \\
\hline Karagass & $m^{1}$ & 3 & 1 \\
\hline \multirow{2}{*}{ Taigi } & $m^{1}$ & $3,10,11$ & 3 \\
\cline { 2 - 4 } & $m^{2}$ & 12 & 3 \\
\hline
\end{tabular}

$$
\text { 2. }{ }^{*} l m
$$

\begin{tabular}{|c|c|c|c|}
\hline Language & Reflexes & Serial numbers of entries & Nr. of occurrences \\
\hline \multirow[t]{3}{*}{$\overline{\overline{\text { Finnic }}}$} & $\overline{l m^{1}}$ & $24,25,27,29,31,33$ & 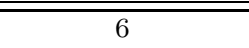 \\
\hline & $l m^{2}$ & $30,32,34$ & 3 \\
\hline & $l m^{2}(l v, l p)$ & 26 & 1 \\
\hline \multirow[t]{4}{*}{ Lapp } & $l m^{1} l^{\prime} b m^{1}$ & 33 & 1 \\
\hline & $l m^{2} l^{\prime} b m^{2}$ & 31 & 1 \\
\hline & $l^{\prime} b m^{1}$ & $24,25,26,27,29$ & 5 \\
\hline & $l^{\prime} b m^{2}$ & 30,34 & 2 \\
\hline \multirow[t]{2}{*}{ Mordvin } & $l m^{1}$ & $24,25,27,31$ & 4 \\
\hline & $l m$ & 33 & 1 \\
\hline \multirow[t]{3}{*}{ Cheremiss } & $\overline{m^{1}}$ & 27 & 1 \\
\hline & $\overline{n^{1}}$ & 25 & 1 \\
\hline & $l m^{1}$ & 26,33 & 2 \\
\hline \multirow[t]{5}{*}{ Votyak } & $m^{2}$ & 34 & 1 \\
\hline & $n{ }^{1} m^{1}$ & 33 & 1 \\
\hline & $n^{2} m^{2}$ & 30 & 1 \\
\hline & $\bar{n}^{1} n^{\prime} m^{1}$ & 27 & 1 \\
\hline & $n^{1} m^{1}, n^{1}, n^{1}{ }^{1}$ & 25,28 & 2 \\
\hline \multirow[t]{5}{*}{ Zyrian } & $n, m^{1}$ & $25,29,33$ & 3 \\
\hline & $n^{2} m^{2}$ & 30 & 1 \\
\hline & $n^{2}$ & 34 & 1 \\
\hline & $n^{2}\left(<? n^{\prime} m^{2}\right)$ & 32 & 1 \\
\hline & $j 3 m^{1}, m^{1}$ & 27 & 1 \\
\hline \multirow[t]{2}{*}{ Ostyak } & $m^{1}$ & 25 & 1 \\
\hline & $l 3 m^{1}$ & $26,27,29$ & 3 \\
\hline \multirow[t]{3}{*}{ Vogul } & $m^{1}$ & 25 & 1 \\
\hline & $l 3 m^{1}$ & $26,28,29$ & 3 \\
\hline & $r 3 m^{1}$ & 27 & 1 \\
\hline
\end{tabular}




\begin{tabular}{|l|l|l|c|}
\hline Language & Reflexes & Serial numbers of entries & Nr. of occurrences \\
\hline \hline \multirow{4}{*}{ Hungarian } & $m^{1}$ & 24,25 & 2 \\
\cline { 2 - 4 } & $l 3 m^{1}$ & 28 & 1 \\
\cline { 2 - 4 } & $l v^{1} \sim \overline{3}^{-1}$ & 26 & 1 \\
\cline { 2 - 4 } & $r 3 m^{1}$ & 27 & 1 \\
\hline \multirow{3}{*}{ Yurak } & $w^{1} m^{1}$ & 25 & 1 \\
\cline { 2 - 4 } & $l m^{1}$ & 31 & 1 \\
\hline \multirow{3}{*}{ Yeniseian } & $j^{1}$ & 25 & 1 \\
\cline { 2 - 4 } & $m^{1}$ & 31 & 1 \\
\hline Tavgi & $j m^{1}$ & 25 & 1 \\
\hline Selkup & $j^{1}$ & 25 & 1 \\
\hline \multirow{2}{*}{ Kamass } & $m^{1}$ & 25 & 1 \\
\cline { 2 - 4 } & $l m^{1}$ & 31 & 1 \\
\hline Koibal & $m^{1}$ & 25 & 1 \\
\hline Motor & $m^{1}$ & 25 & 1 \\
\hline Karagass & $m^{1}$ & 25 & 1 \\
\hline Taigi & $m^{1}$ & 25 & 1 \\
\hline
\end{tabular}

\section{3. ${ }^{*} l 3 m$}

\begin{tabular}{|l|l|l|c|}
\hline Language & Reflexes & Serial numbers of entries & Nr. of occurrences \\
\hline \hline Lapp & $l_{3} m^{1}$ & 37 & 1 \\
\hline Mordvin & $l_{3} m^{1}, l_{3} n^{1}$ & 37 & 1 \\
\hline Ostyak & $l 3 m^{1}$ & 35,36 & 2 \\
\hline Vogul & $l 3 m^{1}$ & 36 & 1 \\
\hline \multirow{2}{*}{ Hungarian } & $l 3 m^{1}$ & 35 & 1 \\
\cline { 2 - 4 } & $l v^{1}, l^{1}, l^{1}$ & 36 & 1 \\
\hline
\end{tabular}

4. ${ }^{*} l m$

\begin{tabular}{|l|l|l|c|}
\hline Language & Reflexes & Serial numbers of entries & Nr. of occurrences \\
\hline \hline \multirow{3}{*}{ Finnic } & $l m^{1}$ & 38 & 1 \\
\cline { 2 - 4 } & $l m^{2}$ & 39 & 1 \\
\cline { 2 - 4 } & $m^{1}$ & 40 & 1 \\
\hline Lapp & $l^{\prime} b m^{2}$ & 38 & 1 \\
\hline \multirow{2}{*}{ Votyak } & $n^{2}, n^{2} m^{2}$ & 39 & 1 \\
\cline { 2 - 4 } & $l m^{1}, m^{1}, m^{1}$ & 40 & 1 \\
\hline \multirow{2}{*}{ Zyrian } & $3 m^{3}, j 3 m^{3}$ & 39 & 1 \\
\cline { 2 - 4 } & $m^{1}$ & 40 & 1 \\
\hline Ostyak & $l 3 m^{1}$ & 38 & 1 \\
\hline Yurak & $w^{1} m^{1}$ & 40 & 1 \\
\hline Yeniseian & $j^{1}$ & 40 & 1 \\
\hline Tavgi & $m^{1}$ & 40 & 1 \\
\hline
\end{tabular}


$5 .{ }^{*}{ }_{\Lambda} m$

\begin{tabular}{|l|l|l|c|}
\hline Language & Reflexes & Serial numbers of entries & Nr. of occurrences \\
\hline \hline Lapp & $r m^{1}$ & 41 & 1 \\
\hline Ostyak & $m^{1}$ & 41 & 1 \\
\hline Yurak & $j^{2}$ & 41 & 1 \\
\hline Kamass & $j 3 m^{2}$ & 41 & 1 \\
\hline
\end{tabular}

6. ${ }^{*} \Lambda 3 m$

\begin{tabular}{|c|c|c|c|}
\hline Language & Reflexes & Serial numbers of entries & Nr. of occurrences \\
\hline Finnic & $d 3 m^{1}$ & $43,44,45$ & 3 \\
\hline \multirow[t]{2}{*}{ Lapp } & ${ }^{\prime} d d 3 m^{1}, m^{1}$ & 43 & 1 \\
\hline & $d d 3 m^{1}, m^{1}$ & 44 & 1 \\
\hline \multirow[t]{3}{*}{ Mordvin } & $d 3 m^{1}$ & 42 & 1 \\
\hline & $d_{3} j^{1}, d_{3} \eta^{1} d_{3}{ }^{1}$ & 43 & 1 \\
\hline & $d 3 m^{1}$ & 44 & 1 \\
\hline Cheremiss & $\overline{m^{1}}$ & $42,43,44$ & 3 \\
\hline \multirow[t]{4}{*}{ Votyak } & $m^{1}, n m^{1} m m^{1}$ & 42 & 1 \\
\hline & $l 3 m^{1}$ & 43 & 1 \\
\hline & $j 3 m^{1} m^{1}$ & 44 & 1 \\
\hline & $n^{2} n m^{2}$ & 45 & 1 \\
\hline \multirow[t]{4}{*}{ Zyrian } & $n, n^{1} n m^{1}$ & 42 & 1 \\
\hline & $l 3 m^{1}$ & 43 & 1 \\
\hline & $m^{1}$ & 44 & 1 \\
\hline & $n^{2} n j^{2}$ & 45 & 1 \\
\hline \multirow[t]{3}{*}{ Ostyak } & $l_{3 m^{1}}$ & 42,44 & 2 \\
\hline & $m^{1}$ & 43 & 1 \\
\hline & $l_{3} C^{1}$ & 45 & 1 \\
\hline \multirow[t]{3}{*}{ Vogul } & $l 3 m^{1}$ & 42,44 & 2 \\
\hline & $m^{1}$ & 43 & 1 \\
\hline & $m 3 l^{1}$ & 45 & 1 \\
\hline \multirow[t]{3}{*}{ Hungarian } & $l 3 m^{1}$ & 42 & 1 \\
\hline & $v^{1} \overline{3}^{1}$ & 43 & 1 \\
\hline & $l \overline{3}^{1}$ & 44 & 1 \\
\hline Yurak & $j^{1}$ & 43 & 1 \\
\hline Yeniseian & $j_{,}^{1} \emptyset^{1}$ & 43 & 1 \\
\hline Tavgi & $\emptyset^{1}$ & 43 & 1 \\
\hline Selkup & $\check{c}^{1} d^{1}$ & 43 & 1 \\
\hline Kamass & $\emptyset^{1}$ & 43 & 1 \\
\hline Koibal & $j^{1}$ & 43 & 1 \\
\hline Motor & $j^{1}$ & 43 & 1 \\
\hline Karagass & $j^{1}$ & 43 & 1 \\
\hline Taigi & $j^{1}$ & 43 & 1 \\
\hline
\end{tabular}




\begin{tabular}{|l|l|l|c|}
\hline Language & Reflexes & Serial numbers of entries & Nr. of occurrences \\
\hline \hline Mordvin & $l 3 v^{2} l l_{3 \eta}^{2}, l^{2}$ & 46 & 1 \\
\hline Ostyak & $j 3 m^{1}$ & 46 & 1 \\
\hline Vogul & $l_{3} m^{1}$ & 46 & 1 \\
\hline Hungarian & $m^{1}$ & 46 & 1 \\
\hline
\end{tabular}

8. ${ }^{*} \Lambda$ s $m$ or ${ }^{*} \Lambda m$

\begin{tabular}{|l|l|l|c|}
\hline Language & Reflexes & Serial numbers of entries & Nr. of occurrences \\
\hline \hline Ostyak & ${ }^{j} 3 m^{1}$ & 47 & 1 \\
\hline Vogul & $l^{l} m^{1}$ & 47 & 1 \\
\hline Hungarian & ${ }^{*} n{ }^{1}{ }^{1}, n^{\prime} v^{1}$ & 47 & 1 \\
\hline
\end{tabular}

$$
\text { 9. }{ }^{*} r m
$$

\begin{tabular}{|c|c|c|c|}
\hline Language & Reflexes & Serial numbers of entries & Nr. of occurrences \\
\hline \multirow[t]{3}{*}{ Finnic } & $\overline{r m^{1}}$ & $\overline{5} 51,52,54,55,57,58,61,64$ & 8 \\
\hline & $\overline{r m^{2}}$ & 65 & 1 \\
\hline & $r m^{3}$ & 56,59 & 2 \\
\hline \multirow[t]{7}{*}{ Lapp } & $r m^{1}$ & 54 & 1 \\
\hline & $r^{\prime} m^{1}$ & 55 & 1 \\
\hline & $\bar{r} m^{1}$ & 62 & 1 \\
\hline & $\overline{r b m^{2}}$ & 49 & 1 \\
\hline & $r^{\prime} b m^{1}$ & 61 & 1 \\
\hline & $r^{\prime} b m^{2}$ & 63 & 1 \\
\hline & $r^{\prime} b m^{3}$ & 65 & 1 \\
\hline \multirow[t]{6}{*}{ Mordvin } & $r^{1}$ & 61 & 1 \\
\hline & $r m^{1}$ & 53,59 & 2 \\
\hline & $r m^{2}$ & 50 & 1 \\
\hline & $r m^{3}$ & 56 & 1 \\
\hline & $r 3 m^{1}$ & 57 & 1 \\
\hline & $r v^{1}$ & 51 & 1 \\
\hline Cheremiss & $r m^{1}$ & $51,52,53,57$ & 4 \\
\hline \multirow[t]{2}{*}{ Votyak } & $r m^{2}$ & 48 & 1 \\
\hline & $r 3 m^{1}$ & 53 & 1 \\
\hline \multirow[t]{2}{*}{ Zyrian } & $r^{2}$ & 49 & 1 \\
\hline & $r 3 m^{1}$ & 53 & 1 \\
\hline \multirow[t]{4}{*}{ Ostyak } & $r 3 m^{1}$ & $54,55,58,64$ & 4 \\
\hline & $r 3 m^{2}$ & 65 & 1 \\
\hline & $r 3 m^{3}$ & 62 & 1 \\
\hline & $m 3 r^{1}$ & 59 & 1 \\
\hline
\end{tabular}

\section{Acta Linguistica Hungarica 60, 2013}




\begin{tabular}{|l|l|l|c|}
\hline Language & Reflexes & Serial numbers of entries & Nr. of occurrences \\
\hline \hline \multirow{3}{*}{ Vogul } & $r 3 m^{1}$ & $54,55,60,64$ & 4 \\
\cline { 2 - 4 } & $r 3 \eta^{2}$ & 65 & 1 \\
\hline \multirow{5}{*}{ Yurak } & $r^{2}$ & 49 & 1 \\
\cline { 2 - 4 } & $r w^{1}$ & 60 & 1 \\
\cline { 2 - 4 } & $r w^{2}$ & 50 & 1 \\
\cline { 2 - 4 } & $r m^{1}$ & 62 & 1 \\
\cline { 2 - 4 } & $r m^{2}$ & 63 & 1 \\
\hline \multirow{5}{*}{ Yeniseian } & $\partial^{2}$ & 49 & 1 \\
\cline { 2 - 4 } & $m^{1}$ & 60,62 & 2 \\
\cline { 2 - 4 } & $m^{2}$ & 52 & 1 \\
\hline \multirow{3}{*}{ Tavgi } & $r^{2}$ & 49 & 1 \\
\cline { 2 - 4 } & $r b^{2}$ & 50 & 1 \\
\hline \multirow{3}{*}{ Selkup } & $r^{2}$ & 49 & 1 \\
\cline { 2 - 4 } & $r m^{2}$ & 48 & 1 \\
\cline { 2 - 4 } & $r 3 m^{1}$ & 62 & 1 \\
\hline Kamass & $r^{2}\left(<*^{*} r m\right)$ & 60 & 1 \\
\hline Motor & $r^{3}$ & 50 & 1 \\
\cline { 2 - 4 } & $\dot{r}^{2}$ & 49 & 1 \\
\hline Taigi & $r m^{1}$ & 62 & 1 \\
\hline
\end{tabular}

10. ${ }^{*} r 3 m$

\begin{tabular}{|l|l|l|c|}
\hline Language & Reflexes & Serial numbers of entries & Nr. of occurrences \\
\hline \hline Cheremiss & $r 3 m^{2}$ & 66 & 1 \\
\hline Votyak & $r 3 m^{2}$ & 66 & 1 \\
\hline Zyrian & $r 3 m^{2}$ & 66 & 1 \\
\hline
\end{tabular}

11. ${ }^{*} j m$

\begin{tabular}{|l|l|l|c|}
\hline Language & Reflexes & Serial numbers of entries & Nr. of occurrences \\
\hline \hline \multirow{3}{*}{ Finnic } & $i m^{1}(=j m)$ & $68,69,71$ & 3 \\
\cline { 2 - 4 } & $3 m^{2}$ & 72 & 1 \\
\hline \multirow{5}{*}{ Lapp } & $i^{\prime} b m^{1}$ & 68 & 1 \\
\cline { 2 - 4 } & $i^{\prime} b m^{1} \mathrm{im}^{1}$ & 71 & 1 \\
\cline { 2 - 4 } & $i^{\prime} b m^{2}, i m^{2}$ & 72 & 1 \\
\hline \multirow{3}{*}{ Mordvin } & $m^{1}$ & 69 & 1 \\
\cline { 2 - 4 } & $j^{1}$ & 71 & 1 \\
\hline Cheremiss & $m^{1}$ & 68 & 1 \\
\hline \multirow{3}{*}{ Votyak } & $m^{1}$ & 67,69 & 2 \\
\cline { 2 - 4 } & $m^{2}$ & 70 & 1 \\
\cline { 2 - 4 } & $m^{4}$ & 72 & 2 \\
\hline \multirow{2}{*}{ Zyrian } & $m^{1}$ & 67,68 & 1 \\
\cline { 2 - 4 } & $m^{4}$ & 72 & 2 \\
\hline Ostyak & $m^{2}$ & 69,70 & 1 \\
\hline
\end{tabular}




\begin{tabular}{|l|l|l|c|}
\hline Language & Reflexes & Serial numbers of entries & Nr. of occurrences \\
\hline \hline \multirow{2}{*}{ Vogul } & $m^{1}$ & 67 & 1 \\
\cline { 2 - 4 } & $m^{2}$ & 70 & 1 \\
\hline Hungarian & $m^{1}$ & 67 & 1 \\
\hline Yurak & $p^{1}$ & 68 & 1 \\
\hline Yeniseian & $\emptyset^{1}$ & 68 & 1 \\
\hline Tavgi & $j m^{1}$ & 68 & 1 \\
\hline \multirow{2}{*}{ Selkup } & $p^{1} m^{1}$ & 67 & 1 \\
\cline { 2 - 4 } & $m m^{2}$ & 69 & 1 \\
\hline Kamass & $m^{1}$ & 68 & 1 \\
\hline Koibal & $m^{1}$ & 68 & 1 \\
\hline Motor & $m^{1}$ & 68 & 1 \\
\hline
\end{tabular}

\section{Appendix C: Phonetic symbols}

$$
\begin{aligned}
C & =\text { any consonant } \\
\check{\delta} & =\text { any short velar vowel } \\
\ddot{\delta} & =\text { any short palatal vowel } \\
\bar{\delta} & =\text { any long velar vowel } \\
3 & =\text { any short vowel } \\
\overline{3} & =\text { any long vowel }
\end{aligned}
$$

\section{Appendix D: Abbreviations of languages and dialects}

$$
\begin{aligned}
\text { altmd. } & =\text { altmordwinisch (Old Mordvin) } \\
\text { Cher } & =\text { Cheremiss } \\
\text { EAH } & =\text { Early Ancient Hungarian } \\
\text { EOT } & =\text { East Old Turkic } \\
\text { Est } & =\text { Estonian } \\
\text { fi. } & =\text { finnisch (Finnish) } \\
\text { Finn } & =\text { Finnish } \\
\text { FP } & =\text { Finno-Permian } \\
\text { FU } & =\text { (Proto-)Finno-Ugric } \\
\text { FUgr } & =\text { Finno-Ugric } \\
\text { FW } & =\text { Finno-Volgaic } \\
\mathrm{H} & =\text { Hungarian } \\
\text { R } & =\text { old/obsolete Hungarian word } \\
\text { Kam } & =\text { Kamass } \\
\text { Kar } & =\text { Karagass } \\
\text { Koib } & =\text { Koibal } \\
\text { Lp } & =\text { Lapp }
\end{aligned}
$$




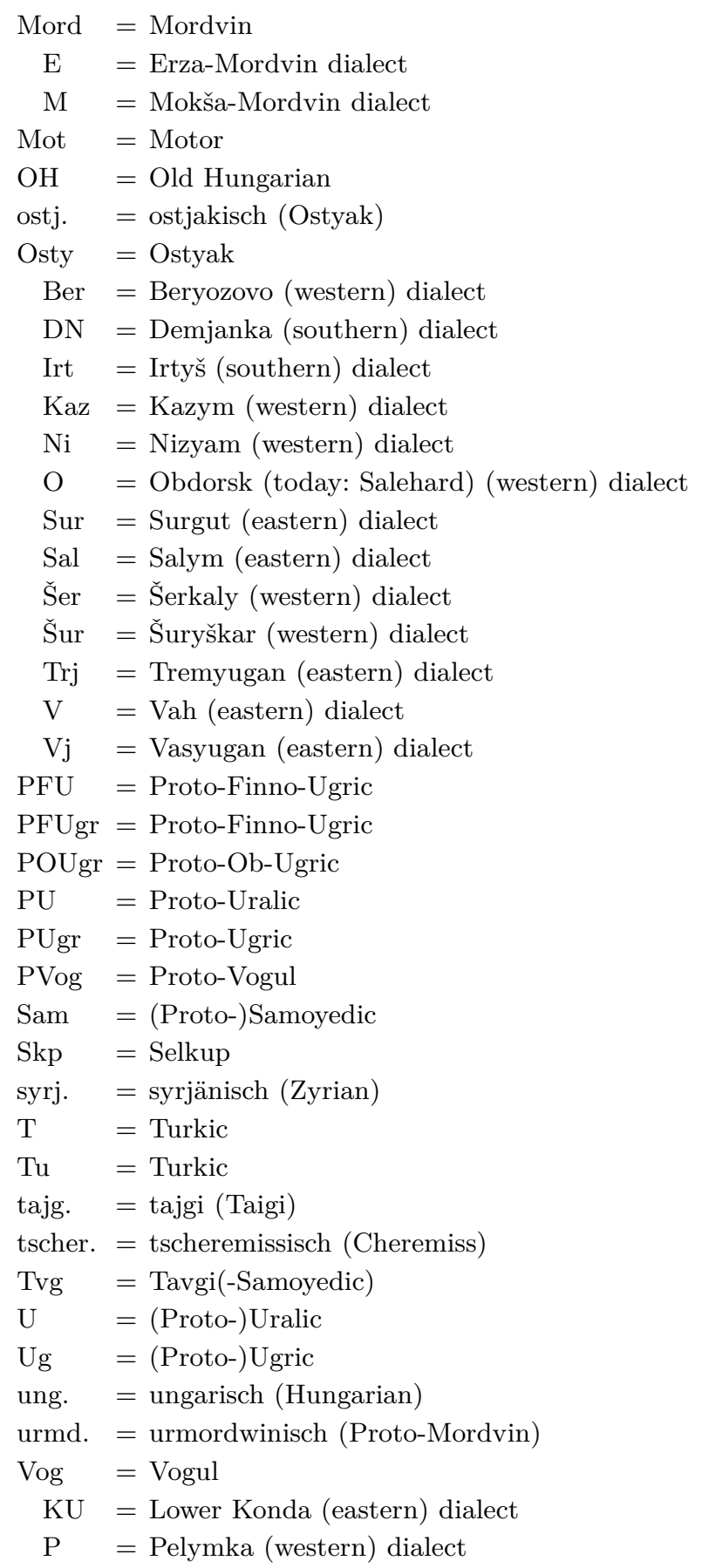




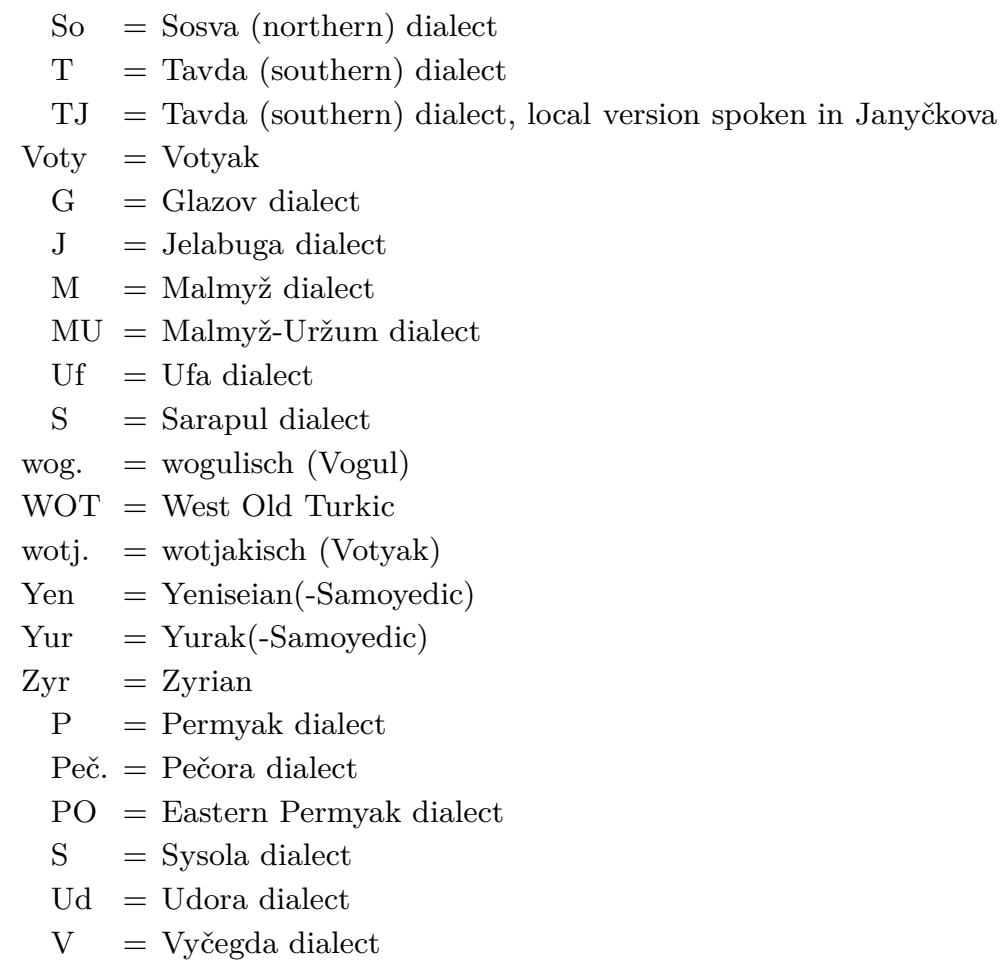

\section{Acknowledgements}

The anonymous reviewers of this paper have contributed useful points on a previous version, for which I am grateful.

\section{References}

E. Abaffy, Erzsébet. 1991. Az ösmagyar fonémarendszer történetéhez [On the history of the phoneme system of Ancient Hungarian]. In M. Hajdú and J. Kiss (eds.) Emlékkönyv Benkő Loránd hetvenedik születésnapjára [A Festschrift for Loránd Benkő on his 70th birthday]. Budapest: ELTE. 27-30.

E. Abaffy, Erzsébet. 1994. Ősmagyar jövevényszavaink vallomása egykorú fonémarendszerünkröl [What ancient loans tell us about the phoneme system of Ancient Hungarian]. A Magyar Nyelvtudományi Társaság Kiadványai 200. 9-20.

E. Abaffy, Erzsébet. 2003. Hangtörténet [Historical phonology]. In J. Kiss and F. Pusztai (eds.) Magyar nyelvtörténet [The history of Hungarian]. Budapest: Osiris Kiadó. 106-128.

Bakró-Nagy, Marianne. 2001. A rekonstrukció valószínűsége. A hangtani rekonstrukció valószínüsége [On the possibility of phonological reconstruction]. In B. Oszkó

Acta Linguistica Hungarica 60, 2013 
and M. Sipos (eds.) Budapesti Uráli Műhely II. Budapest: MTA Nyelvtudományi Intézet. $15-24$.

Bárczi, Géza. 1947a. A történeti nyelvjáráskutatás [Historical dialectology]. Magyar Nyelv 43. 81-91.

Bárczi, Géza. 1947b. Régi magyar nyelvjárások. Magyar Népkutatás kézikönyve [Old Hungarian dialects. A handbook of Hungarian ethnography]. Budapest: Néptudományi Intézet.

Bárczi, Géza. 1953. Bevezetés a nyelvtudományba [An introduction to linguistics]. Egyetemi Magyar Nyelvészeti Füzetek. Budapest: Tankönyvkiadó.

Bárczi, Géza. 1958. Magyar hangtörténet. Második, bővített kiadás [Historical phonology of Hungarian. Second, enlarged ed.]. Budapest: Tankönyvkiadó.

Benkő, Loránd (ed.). 1967. A magyar nyelv történeti-etimológiai szótára I. A-Gy [Etymological-historical dictionary of the Hungarian language 1. A-Gy]. Budapest: Akadémiai Kiadó. = TESz 1 .

Benkő, Loránd (ed.). 1970. A magyar nyelv történeti-etimológiai szótára II. H-Ó [Etymologic-historical dictionary of the Hungarian language 2. H-Ó]. Budapest: Akadémiai Kiadó. = TESz 2 .

Benkő, Loránd (ed.). 1976. A magyar nyelv történeti-etimológiai szótára III. Ö-Zs [Etymologic-historical dictionary of the Hungarian language 3. Ö-Zs]. Budapest: Akadémiai Kiadó. = TESz 3 .

Castrén, M. Alexander. 1858/1969. Versuch einer ostjakischen Sprachlehre nebst kurzem Wörterverzeichnis. Zweite verbesserte Auflage. Nordische Reisen und Forschungen 6. St. Petersburg/Leipzig: Kaiserliche Akademie der Wissenschaften/Zentralantiquariat der Deutschen Demokratischen Republik.

Collinder, Björn. 1960. Comparative grammar of the Uralic languages. Stockholm: Almqvist \& Wiksells.

Csúcs, Sándor. 2005. Die Rekonstruktion der permischen Grundsprache. Budapest: Akadémiai Kiadó.

Csúcs, Sándor and Zoltán Molnár. 2009. Alternatív rekonstruktumok az UEW-ben. [Alternative reconstructions in UEW]. Nyelvtudományi Közlemények 106. 7-71.

Décsy, Gyula. 1969a. Die Streitfragen der finnougrischen Lautforschung. Ural-Altaische Jahrbücher 41. 183-211.

Décsy, Gyula. 1969b. Finnougrische Lautforschung. Ural-Altaische Jahrbücher 41. 3375.

Eek, Arvo. 1982. Л. А. Верте, Консонантизм хантыйского языка (экспериментальное исследование). Диссертация на соискание ученой степени кандидата филологических наук. Советское финно-угроведение 18. 309-311.

EES $=$ Metsmägi (2012) .

Genetz, Arvid. 1896. Suomalais-ugrilainen $\partial$ ensimmäisen ja toisen tavuun vokaalien välissä [Finno-Ugric $\partial$ between the first and the second syllable]. Suomi 3. 57-78.

Hajdú, Péter. 1987. Die uralischen Sprachen. In P. Hajdú and P. Domokos: Die uralischen Sprachen und Literaturen. Budapest \& Hamburg: Akadémiai Kiadó \& Helmut Buske Verlag. 21-450.

Häkkinen, Kaisa. 2007. Nykysuomen etymologinen sanakirja [An etymological dictionary of Present-day Finnish]. Juva: WS Bookwell Oy.

Acta Linguistica Hungarica 60, 2013 
Helimskij, Е. А. [Хелимский, Е. А.] 1987. Правило Хонти для венг. fészek и его аналог в маторско-тайгийско-карагасском языке. Советское финно-угроведение 23. $57-60$.

Honti, László. 1980. Zur Frage nach dem Wechsel „Affrikate/Sibilant homorganer Verschlußlaut" im Ostjakischen. Acta Linguistica Academiae Scientiarum Hungaricae 30. $1-24$.

Honti, László. 1983. Zur ugrischen Lautgeschichte (Beiträge zur relativen Chronologie einiger Lautwandel in den ugrischen Sprachen). Acta Linguistica Academiae Scientiarum Hungaricae 33. 113-122.

Honti, László. 1984. Chrestomathia Ostiacica. Budapest: Tankönyvkiadó.

Honti, László. 1992. Adalék a magyar $l \sim$ finn $t$ megfelelésének és alapnyelvi előzményének magyarázatához [On the correspondence between Hungarian $l \sim$ Finnish $t$ and their origins in the base language]. In P. Deréky, T. Riese, M. Sz. Bakró-Nagy and P. Hajdú (eds.) Festschrift für Károly Rédei zum 60. Geburtstag/Emlékkönyv Rédei Károly 60. születésnapjára. Wien \& Budapest: Institut für Finno-Ugristik der Universität Wien \& MTA Nyelvtudományi Intézet. 209-213.

Honti, László. 2001. Ung. tó 'See' fi. suo 'Morast', ung. toll fi. sulka 'Feder' (Ein Beitrag zum Konsonantismus der U/FU Grundsprache). Linguistica Uralica 37. 241-244

Honti, László. 2004. „The missing link”, avagy rokon-e a magyar toll és a finn sulka? [Are Hungarian toll and Finnish sulka related?]. In E. Mészáros, S. Szeverényi and B. Wagner-Nagy (eds.) Mikola-konferencia 2002. Szeged: SzTE Finnugor Tanszék. $75-84$.

Itkonen, Erkki. 1946. Zur Frage nach der Entwicklung des Vokalismus der ersten Silbe in den finnisch-ugrischen Sprachen, insbesondere im Mordwinischen. Finnischugrische Forschungen 29. 222-337.

Itkonen, Erkki. 1954. Zur Geschichte des Vokalismus der ersten Silbe im Tscheremissischen und in den permischen Sprachen. Finnisch-ugrische Forschungen 31. 149-345.

Itkonen, Erkki. 1956a. Etymologische Beiträge. In G. Bárczi and L. Benkő (eds.) Emlékkönyv Pais Dezső hetvenedik születésnapjára. [A Festschrift for Dezső Pais on his 70th birthday]. Budapest: Akadémiai Kiadó. 616-622.

Itkonen, Erkki. 1956b. Neue Zeitschriften. Finnisch-ugrische Forschungen 32. 56-86.

Itkonen, Erkki. 1969. Zur Wertung der finnisch-ugrischen Lautforschung. Ural-Altaische Jahrbücher 41. 76-111.

Itkonen, Erkki. 1975. Etymologisia lisiä [Etymological remarks]. Virittäjä 1975. 168-178.

Itkonen, Erkki and Ulla-Maija Kulonen (eds.). 1992. Suomen sanojen alkuperä 1 A-K [The origin of Finnish words 1 A-K]. Helsinki: Suomalaisen Kirjallisuuden Seura and Kotimaisten kielten tutkimuskeskus. $=$ SSA 1.

Itkonen, Terho. 1982. Suvannosta tyveneen [From calm waters to doldrums]. In Språkhistoriska och språkkontakt i Finland och Nord-Skandinavien. Studien tillägnade Tryggve Sköld den 2 december 1982. Umeå: Skytteanska samfundet. 157-165.

Janhunen, Juha. 1981. Uralilaisen kantakielen sanastosta [On the Proto-Uralic word stock]. Journal de la Société Finno-ougrienne 77. 219-274.

Janhunen, Juha. 1982. On the structure of Proto-Uralic. Finnisch-ugrische Forschungen 44. $11-22$.

Acta Linguistica Hungarica 60, 2013 
Karjalainen, K. F. 1905. Zur ostjakischen Lautgeschichte. I. Über den Vokalismus der ersten Silbe. Mémoires de la Société Finno-ougrienne 23.

Katz, Hartmut. 1975. Generative Phonologie und phonologische Sprachbünde des Ostjakischen und Samojedischen. München: Wilhelm Fink Verlag.

Kazantsev, D. Е. [Казанцев, Д. Е.] 1990. К вопросу о реконструкции $* \delta$ и * финно-угорском праязыке. Linguistica Uralica 26. 173-179.

Keresztes, László. 1987. Geschichte des mordwinischen Konsonantismus I (Studia UraloAltaica 27). Szeged: JATE.

KESK $=$ Lytkin \& Guljaev (1999).

Kiparsky, Valentin. 1966. Etymologie gestern und heute. Kratylos 11. 68-78.

Koivulehto, Jorma. 1976. Vanhimmista germaanisista lainakosketuksista ja niiden ikäämisestä II [On the oldest Finnic-Germanic contacts and their chronology 2]. Virittäjä 80. 247-290.

Korhonen, Mikko. 1981. Johdatus lapin kielen historiaan [Introduction to the history of Lapp] (Suomalaisen Kirjallisuuden Seuran toimituksia 370). Helsinki: Suomalaisen Kirjallisuuden Seura.

Korhonen, Mikko. 1990. Glottogenetik und Sprachgeschichte. In L. Keresztes and S. Maticsák (eds.) Congressus Septimus Internationalis Fenno-Ugristarum 1. A. Sessiones plenare. Debrecen. 159-178.

Kulonen, Ulla-Maij (ed.). 1995. Suomen sanojen alkuperä 2. L-P [The origin of Finnish words 2. L-P]. Helsinki: Suomalaisen Kirjallisuuden Seura and Kotimaisten kielten tutkimuskeskus. $=$ SSA 2 .

Kulonen, Ulla-Maij (ed.). 2000. Suomen sanojen alkuperä 3. R-Ö [The origin of Finnish words 3. R-Ö]. Helsinki: Suomalaisen Kirjallisuuden Seura and Kotimaisten kielten tutkimuskeskus. $=$ SSA 3 .

Kylstra, Andries Dirk, Sirkka-Liisa Hahmo, Tette Hofstra and Osmo Nikkilä. 1991. Lexikon der älteren germanischen Lehnwörter in den ostseefinnischen Sprachen. Bd. I: A-J. Amsterdam \& Atlanta: Rodopi.

Lakó, György. 1962. Voltak-e a finnugor alapnyelvben szókezdő zöngés zárhangok? [Were there word-initial voiced stops in Finno-Ugric?]. Nyelvtudományi Közlemények 64. $56-70$.

Lakó, György (ed.). 1967. A magyar szókészlet finnugor elemei. Etimológiai szótár. I. kötet. A-Gy [The Finno-Ugric elements of the Hungarian word stock. Etymological dictionary. Vol. 1. A-Gy]. Budapest: Akadémiai Kiadó. = MSzFE 1.

Lakó, György. 1968. Proto-Finno-Ugric sources of the Hungarian phonetic stock. Budapest: Akadémiai Kiadó.

Lakó, György (ed.). 1971. A magyar szókészlet finnugor elemei. Etimológiai szótár. II. kötet. H-M [The Finno-Ugric elements of the Hungarian word stock. Etymological dictionary. Vol. 2. H-M]. Budapest: Akadémiai Kiadó. = MSzFE 2.

Lytkin, V. I. [Лыткин, В. И.] 1957. Историческая грамматика коми языка. Часть первая. Введение и фонетика. Сыктывкар: Коми книжное издательство.

Lytkin, V. I. and E. S. Guljaev [Лыткин, В. И. \& Гуляев, Е. С.] 1999. Краткий этимологический словарь коми языка. Сыктывкар: Коми книжное издательство. = KESK. 
Merlingen, Weriand. 1984. Laterale in altertümlichen Sprachen. In O. Gschwantler, K. Rédei and H. Reichert (eds.) Linguistica et Philologica. Gedenkschrift für Björn Collinder (1894-1984). Braumüller: Wien. 331-337.

Metsmägi, Iris (ed.). 2012. Eesti etümoloogiasõnaraamat [An etymological dictionary of Estonian]. Tallinn: Eesti Keele Sihtasutus. = EES.

Mikola, Tibor. 1976. Hangtan és jelentéstan az etimológiában [Phonology and semantics in etymology]. Nyelvtudományi Értekezések 89. 209-212.

Mikola, Tibor. 2004. Studien zur Geschichte der samojedischen Sprachen (Studia UraloAltaica 45). Szeged: SzTE Finnisch-Ugrisches Institut.

MSzFE 1 = Lakó (1967).

MSzFE 2 = Lakó (1971).

Rédei, Károly. 1967. A létige jelen idejü alakjai a permi nyelvekben [The present tense forms of the copula in Permian languages]. Nyelvtudományi Közlemények 69. 164166.

Rédei, Károly. 1968. Nordostjakische Texte (Kazym-Dialekt) mit Skizze der Grammatik. Abhandlungen der Akademie der Wissenschaften in Göttingen. PhilosophischHistorische Klasse. Dritte Folge. Nr. 71. Göttingen: Vandenhoeck \& Ruprecht.

Rédei, Károly. 1976. Szóképzés a PU/PFU alapnyelvben [Word-formation in ProtoUgric/Proto-Finno-Ugric]. Nyelvtudományi Értekezések 89. 255-262.

Rédei, Károly. 1980. Szófejtések [Etymologies]. Nyelvtudományi Közlemények 82. 260264.

Rédei, Károly. 1988a. Geschichte der permischen Sprachen. In Sinor (1988, 351-394).

Rédei, Károly. 1988b. Suomen huuli-sanan alkuperästä [On the origin of Finnish huuli 'lip']. Virittäjä 1988. 177-178.

Rédei, Károly (ed.). 1988c. Uralisches etymologisches Wörterbuch. Band I. Uralische und finnisch-ugrische Schicht. Budapest \& Wiesbaden: Akadémiai Kiadó \& Otto Harrassowitz. = UEW 1 .

Rédei, Károly (ed.). 1988d. Uralisches etymologisches Wörterbuch. Band II. Finnischpermische und finnisch-wolgaische und finnisch-ugrische Schicht. Ugrische Schicht. Budapest \& Wiesbaden: Akadémiai Kiadó \& Otto Harrassowitz. = UEW 2.

Rédei, Károly. 1991. Szófejtések [Etymologies]. Nyelvtudományi Közlemények 92. 83111.

Rešetnikov, K. Ju. [Решетников, К. Ю] 2011. Новые этимологии для прибалтийскофинских слов. Ural-Altaic Studies 5. 109-112.

Róna-Tas, András and Árpád Berta. 2011a. West Old Turkic. Turkic loanwords in Hungarian. Part 1: Introduction, Lexicon: A-K (Turcologica 84). Wiesbaden: Harrassowitz.

Róna-Tas, András and Árpád Berta. 2011b. West Old Turkic. Turkic loanwords in Hungarian. Part 2: Introduction, Lexicon: L-Z, Conclusions, Apparatus (Turcologica 84). Wiesbaden: Harrassowitz.

Salánki, Zsuzsa. 1991. Kononanten im Wortinlat. In S. Csúcs, L. Honti, Zs. Salánki and J. Varga (eds.) Statistik der uralischen Lautentsprechungen. Linguistica, Series B, Documenta, 1. Budapest: MTA Nyelvtudományi Intézete. 127-231.

Sammallahti, Pekka. 1979. Über die Laut- und Morphemstruktur der uralischen Sprachen. Finnisch-ugrische Forschungen 43. 22-66. 
Sammallahti, Pekka. 1988. Historical phonology of the Uralic languages. In Sinor (1988, 478-554).

Setälä, Emil Nestor. 1896. A finn-ugor $\delta$ és $\delta$ [Finno-Ugric $\delta$ and $\delta$ ]. Nyelvtudományi Közlemények 26. 377-437.

Setälä, Emil Nestor. 1912. Über Art, Umfang und Alter des Stufenwechsels im FinnischUgrischen und Samojedischen. Finnisch-ugrische Forschungen 12. 1-128.

Sinor, Denis (ed.). 1988. The Uralic languages. Description, history and foreign influences. Handbuch der Orientalistik. Leiden: E. J. Brill.

SKES $1=$ Toivonen (1955).

SSA $1=$ Itkonen \& Kulonen (1992).

SSA $2=$ Kulonen (1995).

SSA 3 = Kulonen (2000).

Steinitz, Wolfgang. 1937/1980. Хантыйски (остяцкий) язык. In Prokof'ev, G. N. [Прокофьев, Г. Н.] (еd.) Языки и письменность народов Севера. Часть I. Москва \& Ленинград: Учпедгиз. 193-227. In: Steinitz, Wolfgang, Beiträge zur Sprachwissenschaft und Ethnographie. Ostjakologische Arbeiten. Band IV. Akadémiai Kiadó \& Akademie-Verlag \& Mouton, Budapest \& Berlin \& Den Haag.

Steinitz, Wolfgang. 1952. Geschichte des finnisch-ugrischen Konsonantismus. Separatum ex Actis Instituti Hungarici Universitatis Holmiensis. Series B. Linguistica 1. 1539.

Steinitz, Wolfgang. 1980. Справочник по орфоргафии хантыйского языка. In W. Steinitz (ed.) Beiträge zur Sprachwissenschaft und Ethnographie. Ostjakologische Arbeiten. Band IV. Budapest \& Berlin \& Den Haag: Akadémiai Kiadó \& Akademie-Verlag \& Mouton. 63-64.

Terëškin, N. I. [Терёшкин, Н. И.] 1958. О некоторых особенностях ваховского, сургутского и каызмоского диалектов хантыйского языка. В помощь учителю Крайнего Севера 8. Ленинград: Учпедгиз.

Terëškin, N. I. [Терёшкин, Н. И.] 1981. Словарь восточнохантыйских диалектов. Ленинград: Наука. 319-330.

TESz 1 = Benkő (1967).

TESz 2 = Benkő (1970).

TESz 3 = Benkő (1976).

Toivonen, Yrjö Henrik. 1955. Suomen kielen etymologinen sanakirja. I. Lexica Societatis Fenno-Ugricae XII/1 [An etymological dictionary of Finnish]. Helsinki: Suomalaisugrilainen Seura. $=$ SKES 1 .

UEW 1 = Rédei (1988c).

UEW 2 = Rédei (1988d).

Uotila, Toivo Emil. 1933. Zur Geschichte des Konsonantismus in den permischen Sprachen (Mémoires de la Société Finno-ougrienne 65). Suomalais-ugrilainen Seura: Helsinki.

Verte, L. А. [Верте, Л. А.] 1979. Латеральные фонемы [l], [\&], [ح] в в казымском диалекте хантыйского языка. In Nadeljaev, V. М. [Наделяев, В. M.] (ed.) Фонетика сибирских языков (Сборник научных трудов). Новосибирск: Академия наук СССР, Сибирское отделение. 14-27. 
Verte, L. А. [Верте, Л. А.] 1985. Основные характеристики консонантной системы языка казымских ханты. Советское финно-угроведение 21. 38-46.

Verte, L. А. [Верте, Л. А.] 1986. Ассимиляция согласных в языке казымских ханты. In V. M. r. Nadeljaev (ed.) Фонетика языков Сибири и сопредельных регионов. Новосибирск: Наука. 84-88.

Verte, L. А. [Верте, Л. А.] 1989. Фонолого-фонетическая трактовка консонантизма языка казымских ханты. In W. Veenker (ed.) Viertes Internationales Symposion „Uralische Phonologie“ 4.-8. September 1989 in Hamburg. Thesen zu den Vorträgen und Referaten (Mitteilungen der Societas Uralo-Altaica 8). Hamburg. 195-199.

Verte, L. A. 1990. The Kazym-Hanty noise consonants. In Fedjunëva, G. V. [Федюнева, Г. В.] (еd.) Материалы VI международного конгресса финно-угроведов. Том 2. Москва: Наука. 457-459.

Wichmann, Yrjö. 1915. Zur Geschichte der finnisch-ugrischen $l$-Laute $\left({ }^{*} l\right.$ und $\left.{ }^{*} l\right)$, bes. in den permischen Sprachen und im Ostjakischen. Finnisch-ugrische Forschungen 15. $1-55$.

Widmer, Anna. 2007. Morfológia, szófajváltás és etimológia [Morphology, change of word class and etymology]. Folia Uralica Debreceniensia 14. 141-153.

Zinder, L. R. [Зиндер, Л. Р.] 1979. Общая фонетика. Москва: Наука. 